\title{
Antibacterial and Antifungal Activities of Spices
}

\author{
Qing Liu ${ }^{1}$, Xiao Meng ${ }^{1}$, Ya Li ${ }^{1}$, Cai-Ning Zhao ${ }^{1}$, Guo-Yi Tang ${ }^{1}$ and Hua-Bin Li ${ }^{1,2, *}$ \\ 1 Guangdong Provincial Key Laboratory of Food, Nutrition and Health, Department of Nutrition, \\ School of Public Health, Sun Yat-sen University, Guangzhou 510080, China; \\ liuq248@mail2.sysu.edu.cn (Q.L.); mengx7@mail2.sysu.edu.cn (X.M.); liya28@mail2.sysu.edu.cn (Y.L.); \\ zhaocn@mail2.sysu.edu.cn (C.-N.Z.); tanggy5@mail2.sysu.edu.cn (G.-Y.T.) \\ 2 South China Sea Bioresource Exploitation and Utilization Collaborative Innovation Center, \\ Sun Yat-sen University, Guangzhou 510006, China \\ * Correspondence: lihuabin@mail.sysu.edu.cn; Tel.: +86-20-8733-2391
}

Received: 16 May 2017; Accepted: 11 June 2017; Published: 16 June 2017

\begin{abstract}
Infectious diseases caused by pathogens and food poisoning caused by spoilage microorganisms are threatening human health all over the world. The efficacies of some antimicrobial agents, which are currently used to extend shelf-life and increase the safety of food products in food industry and to inhibit disease-causing microorganisms in medicine, have been weakened by microbial resistance. Therefore, new antimicrobial agents that could overcome this resistance need to be discovered. Many spices-such as clove, oregano, thyme, cinnamon, and cumin-possessed significant antibacterial and antifungal activities against food spoilage bacteria like Bacillus subtilis and Pseudomonas fluorescens, pathogens like Staphylococcus aureus and Vibrio parahaemolyticus, harmful fungi like Aspergillus flavus, even antibiotic resistant microorganisms such as methicillin resistant Staphylococcus aureus. Therefore, spices have a great potential to be developed as new and safe antimicrobial agents. This review summarizes scientific studies on the antibacterial and antifungal activities of several spices and their derivatives.
\end{abstract}

Keywords: spice; antibacterial activity; antifungal effect; antimicrobial property; essential oil; clove; oregano; thyme

\section{Introduction}

Microbial pathogens in food may cause spoilage and contribute to foodborne disease incidence, and the emergence of multidrug resistant and disinfectant resistant bacteria-such as Staphylococcus aureus (S. aureus), Escherichia coli (E. coli), and Pseudomonas aeruginosa (P. aeruginosa)-has increased rapidly, causing the increase of morbidity and mortality [1]. Weak acids such as benzoic and sorbic acids [2], which are commonly applied in food industry as chemical preservatives to increase the safety and stability of manufactured foods on its whole shelf-life by controlling pathogenic and spoilage food-related microorganisms [3], can result in the development of microbiological resistance [4]. Moreover, chemical preservatives cannot completely eliminate several pathogenic bacteria like Listeria monocytogenes (L. monocytogenes) in food products or delay the growth of spoilage microorganisms [5]. Natural products, as substitutes of synthetic chemical preservatives, are increasingly accepted because they are innately better tolerated in human body and have inherent superiorities for food industry [4]. The antimicrobial activities of natural products are necessary to be studied and applied in food industry.

Morbidity and mortality are mainly caused by infectious diseases all over the world. The World Health Organization reported that 55 million people died worldwide in 2011, with one-third of the deaths owing to infectious diseases [6]. Antibiotic resistant microorganisms can increase mortality rates because they can survive and recover through their ability to acquire and transmit resistance 
after exposure to antibiotic drugs, which are one of the therapies to infectious diseases [7]. Antibiotic resistant bacteria threaten the antibiotic effectiveness and limit the therapeutic options even for common infections [8]. The decline in research and development of new antibacterial agents, which are able to inhibit antibiotic resistant disease-causing microorganisms such as $S$. aureus, aggravates the emerging antibiotic resistance [9]. Therefore, much attention should be paid to natural products, which could be used as effective drugs to treat human diseases, with high efficacy against pathogens and negligible side effects.

Spices have been used as food and flavoring since ancient times [10], and as medicine and food preservatives in recent decades [11,12]. Many spices-such as clove, oregano, thyme, cinnamon, and cumin - have been applied to treat infectious diseases or protect food because they were experimentally proved to possess antimicrobial activities against pathogenic and spoilage fungi and bacteria $[10,13,14]$. Moreover, the secondary metabolites of these spices are known as antimicrobial agents, the majority of which are generally recognized as safe materials for food with insignificant adverse effects [11]. Therefore, spices could be candidates to discover and develop new antimicrobial agents against foodborne and human pathogens.

This review summarizes the scientific studies on the antibacterial and antifungal activities of spices and their derivatives, and some suggestions and prospects are offered for future studies.

\section{Clove}

Clove (Eugenia caryohyllata), belonging to family Myrtaceae, is widely used in medicine as antiseptic against infectious diseases like periodontal disease due to the antimicrobial activities against oral bacteria [15]. Clove is also commonly applied in food industry as a natural additive or antiseptic to increase shelf-life due to the effective antimicrobial activities against some foodborne pathogens [16]. The main active component of clove oil and extract was found, i.e., eugenol [15,17].

\subsection{Antimicrobial Activities of Clove}

Antimicrobial activities of clove water extract were studied in vitro and in vivo against pathogenic microorganisms (S. aureus and E. coli, in a model of pyelonephritis) [18]. An in vitro study was conducted with the agar well diffusion method, and the results suggested that clove water extract showed antibacterial activity against $S$. aureus (minimum inhibitory concentration (MIC): $2 \mathrm{mg} / \mathrm{mL}$ ) and E. coli (MIC: $2.5 \mathrm{mg} / \mathrm{mL}$ ). While in vivo, the study was conducted in 40 adult male albino rats, and the results confirmed the efficacy of clove extract as natural antimicrobials. The direct antimicrobial activities of ultra-fine powders of ball-milled cinnamon and clove were tested by Kuang et al. [19] against E. coli, S. aureus, Brochothrix thermosphacta (B. thermosphacta), Lactobacillus rhamnosus (L. rhamnosus), and Pseudomonas fluorescens (P. fluorescens) from meat, using broth dilution method. Clove powder showed strong inhibitory effects on five microorganisms tested with the MICs ranging from $1.0 \% w / v$ (L. rhamnosus and B. thermosphacta) to $2.0 \% w / v$ (P. fluorescens), and the inhibitory effects were positively associated with the concentrations of powder, which increased from $0.5 \%$ to $2.5 \% w / v$.

Clove could destroy cell walls and membranes of microorganisms, and permeate the cytoplasmic membranes or enter the cells, then inhibit the normal synthesis of DNA and proteins [16]. Eugenol, the major component of clove, could inhibit the production of amylase and proteases in Bacillus cereus (B. cereus) and has the ability of cell wall deterioration and cell lysis [20].

\subsection{Comparison of Antimicrobial Activities of Clove and Other Spices}

Badei et al. [21] tested the antimicrobial activities of cardamom, cinnamon and clove essential oils (EOs) against nine Gram-positive bacterial strains, four Gram-negative bacterial strains, seven molds, and two yeasts, compared with phenol, using the disc diffusion method. Clove EO showed the highest antimicrobial activity, and the antimicrobial spectra (diameter of inhibition zones) of $10 \%$ clove EO was 1.48 times as that of 10\% phenol. Schmidt et al. [22] evaluated the antifungal 
effects of eugenol-containing EOs of 4 spices on 38 Candida albicans (C. albicans) isolates, of which 12 were isolated from oropharynges, 16 from vaginas, and 10 from damaged skin, using the microdilution method. Clove EO possessed the strongest antifungal activities against all C. albicans strains among the tested spices. Pure eugenol alone exhibited weaker antifungal activities than clove leaf EO. Angienda et al. [23] investigated the antimicrobial activities of EOs of four spices against Salmonella typhimurium (S. typhimurium), E. coli, B. cereus, and Listeria innocua (L. innocua) by agar diffusion test. Clove EO showed the most effective inhibition against both Gram-positive bacteria and Gram-negative bacteria compared with three other EOs, with the MICs ranging from $1.25 \% v / v$ (B. cereus) to $2.50 \% v / v$ (S. typhimurium and E. coli). Lomarat et al. [17] reported the antimicrobial activities of EOs from nine spices against histamine-producing bacteria including Morganella morganii (M. morganii), by determining MICs and minimum bactericidal concentrations (MBCs) using the broth dilution assay, and also found the antibacterial compounds of EOs by bioautography-guided isolation. The results indicated that the clove EO was the most effective against $M$. morganii among nine tested spices with MIC $0.13 \% v / v$ and MBC $0.25 \% v / v$. The eugenol was identified as the active component of clove EO by thin layer chromatography bioautography assay.

Shan et al. [24] tested the antibacterial activities of ethanol extracts from five spices and herbs against L. monocytogenes, S. aureus, and Salmonella enterica (S. enterica) in raw pork by counting bacterial enumeration. When treated with clove extract, raw pork samples were found with the fewest colonies of tested bacteria. Bayoub et al. [25] reported the antimicrobial activities of ethanol extracts of 13 plants including clove against L. monocytogenes, the MICs were determined by agar well diffusion test. The results showed that clove extract was the most effective inhibitor against L. monocytogenes compared with the other 12 selected plant ethanol extracts, with the MIC $0.24 \mathrm{mg} / \mathrm{mL}$. Cui et al. [26] tested the antimicrobial activities of 90 plant extracts (water and $99.5 \%$ ethanol extracts) against Clostridium spp. Clove water extract was found with the greatest antimicrobial activity against Clostridium botulinum in trypticase peptone glucose yeast extract broth $(\mathrm{pH}=7.0)$ among all the water extracts, and the MICs of clove extract ranged from $0.1 \%$ to $0.2 \%$ against Clostridium spp. Antimicrobial effects of 3 extracts (ethyl acetate, acetone, and methanol extracts) of 12 plants were tested on 2 fungi (Kluyveromyces marxianus (K. marxianus) and Rhodotorula rubra (R. rubra)) and 8 bacteria (Klebsiella pneumoniae (K. pneumoniae), Bacillus megaterium (B. megaterium), P. aeruginosa, S. aureus, E. coli, Enterobacter cloacae (E. cloacae), Corynebacterium xerosis (C. xerosis), and Streptococcus faecalis (S. faecalis)) by the disc diffusion method [27]. Clove exhibited the most effective inhibitory impacts. The methanol extract from clove showed inhibition against microorganisms (diameter of inhibition zones (DIZs): 8-24 mm) tested except K. pneumoniae. The acetone extract showed inhibition against microorganisms (DIZs: 8-18 mm) tested except R. rubra and K. pneumoniae. The ethyl acetate extract only showed antibacterial activity against B. megaterium (DIZ: $7 \mathrm{~mm}$ ). Liang et al. [28] observed the antimicrobial activities of seven spices, and different concentrations of extracts and EOs in each spice were used to test the effects on the growth of spoilage microorganisms in apple cider by total plate counts. Clove products showed the strongest antimicrobial activities compared with other spices tested. Nearly seven $\log$ reduction of microorganisms was observed at $0.8 \% v / v$ in the cider for clove oil and $2 \% w / w$ for clove powder at room temperature. Badhe et al. [29] tested the antimicrobial activities of many spice and herb powders against $S$. aureus, S. typhimurium, E. coli, and B. cereus at refrigerated temperature $\left(8 \pm 2{ }^{\circ} \mathrm{C}\right)$ for intervals of $0,3,6,12,24$, and $48 \mathrm{~h}$. The results indicated that at the concentration of $2 \%$, clove powder showed highest effect on S. aureus followed by E.coli and S. typhimurium, and at $24 \mathrm{~h}$ under refrigeration, clove powder led to a significant reduction of bacteria counting.

\subsection{The Application of Clove as Antimicrobial Agents in Food Packaging}

Clove EO and its functional extracts have been incorporated into films, the antimicrobial activities of which have been evaluated in some studies. In a study, chitosan at high, moderate and low molecular mass were elaborated with antimicrobial films which were incorporated with EOs and extracts from two spices [30]. Then the antimicrobial effects of the films were investigated on E. coli, S. typhimurium, 
S. aureus, B. cereus, and L. monocytogenes. The films prepared by low molecular mass chitosan with $2 \% \mathrm{EO}$ and ethyl heptanoate extract from clove showed antimicrobial activities against a majority of the tested strains. In another study, the researchers tested the antimicrobial activities of EOs and functional extracts of cumin, clove, and elecampane against E. coli, S. typhimurium, B. cereus, S. aureus, and L. monocytogenes by determining the MICs and MBCs [31]. They also evaluated the antibacterial activities of edible films prepared by EOs and functional extracts of spices based on chitosan polymeric structure against the same bacteria by determining the DIZs. Clove EO showed the best inhibitory effects with the MIC of $500 \mathrm{mg} / \mathrm{L}$ on all the bacteria tested, clove extracts showed very similar MICs to those of EO, except ethyl caproate extract of clove against L. monocytogenes (MIC of $750 \mathrm{mg} / \mathrm{L}$ ) and ethyl heptanoate extract of clove against B. cereus (MIC of $250 \mathrm{mg} / \mathrm{L}$ ). Among the chitosan films added with EOs, only clove showed inhibition zones of all tested bacteria except $L$. monocytogenes. The ethyl heptanoate extract of clove film also possessed antibacterial activities against all tested bacteria, weaker than those of clove EO though. Liu et al. [32] evaluated the antimicrobial activities of spice EOs against microbial populations in chilled pork stored in PE film antimicrobial package using the disk diffusion method to determine the DIZs and serial dilution assay to determine the MICs. Clove EO was the most effective against microorganisms tested among all the spice EOs tested. The MICs of clove EO were $0.10 \%, 0.10 \%$, and $0.30 \% v / v$ against Enterobacteriaceae, S. aureus, and Pseudomonas sp., respectively. Spice EOs possessed the ability to decrease the number of spoilage populations, but not the species diversity of spoilage microbiota.

Collectively, clove EO and extracts could prevent against some food spoilage and foodborne pathogens (Table 1), especially Gram-positive bacteria. The MICs of clove were less than $2.5 \%$ against tested microorganisms like P. fluorescens, S. typhimurium, E. coli, B. cereus, and L. innocua. Generally speaking, the qualities of the papers cited are good and the results are reliable. 
Table 1. Antibacterial and antifungal activities of clove.

\begin{tabular}{|c|c|c|c|}
\hline Type of Samples & Bacteria and Fungi & Main Results & Reference \\
\hline Clove and cinnamon water extracts & Staphylococcus aureus and Escherichia coli & $\begin{array}{l}\text { Both in vivo and in vitro results confirmed the efficacy of clove } \\
\text { extract as natural antimicrobials. }\end{array}$ & [18] \\
\hline Ultra-fine powders of ball-milled clove & $\begin{array}{l}\text { E. coli, S. aureus, Brochothrix thermosphacta, } \\
\text { Lactobacillus rhamnosus, Pseudomonas fluorescens }\end{array}$ & $\begin{array}{l}\text { Clove powder showed a strong inhibitory effect with the } \\
\text { minimum inhibitory concentrations (MICs) ranging from } 1.0 \% \text { to } \\
2.0 \% w / v \text {. }\end{array}$ & [19] \\
\hline $\begin{array}{l}\text { Cardamom, cinnamon, clove essential } \\
\text { oils (EOs) and phenol }\end{array}$ & 13 bacterial strains, 7 molds and 2 yeasts & Clove EO possessed the highest antimicrobial activities. & [21] \\
\hline 4 spice EOs & Candida albicans & $\begin{array}{l}\text { Clove EO possessed the strongest activities against all C. albicans } \\
\text { strains. }\end{array}$ & [22] \\
\hline 4 spice EOs & $\begin{array}{l}\text { Salmonella typhimurium, E. coli, Bacillus cereus, } \\
\text { Listeria innocua }\end{array}$ & $\begin{array}{l}\text { Clove EO showed the most effective inhibition with the MICs } \\
\text { ranging from } 1.25 \% \text { to } 2.50 \% v / v \text {. }\end{array}$ & [23] \\
\hline 9 spice EOs & Morganella morganii & Clove EO was the most effective with MIC of $0.13 \% v / v$. & [17] \\
\hline Ethanol extracts from 5 spices and herbs & Listeria monocytogenes, S. aureus, Salmonella enterica & Clove extract was the most effective against bacteria tested. & [24] \\
\hline 13 plant ethanol extracts & L. monocytogenes & $\begin{array}{l}\text { Clove extract was the most effective with the MIC of } 0.24 \\
\mathrm{mg} / \mathrm{mL} \text {. }\end{array}$ & [25] \\
\hline 90 plant extracts & Clostridium spp. & $\begin{array}{l}\text { Clove water extract was the most effective among all the water } \\
\text { extracts with the MIC ranging from } 0.1 \% \text { to } 0.2 \% \text {. }\end{array}$ & [26] \\
\hline $\begin{array}{l}\text { Ethyl acetate, acetone and methanol } \\
\text { extracts of } 12 \text { plant species }\end{array}$ & $\begin{array}{l}\text { Kluyveromyces marxianus, Rhodotorula rubra, Klebsiella } \\
\text { pneumoniae, Bacillus megaterium, Pseudomonas aeruginosa, } \\
\text { S. aureus, E. coli, Enterobacter cloacae, } \\
\text { Corynebacterium xerosis, Streptococcus faecalis }\end{array}$ & Clove possessed the most effective inhibitory effects. & [27] \\
\hline 7 spices, their extracts and EOs & Microorganisms in apple cider & $\begin{array}{l}\text { Clove products had the strongest antimicrobial activities } \\
\text { compared with other spices tested. }\end{array}$ & [28] \\
\hline Many spice and herb powders & S. aureus, S. typhimurium, E. coli, B. cereus & $\begin{array}{l}2 \% \text { level of clove powder was more effective against S. aureus } \\
\text { followed by E.coli and S. typhimurium under refrigeration. }\end{array}$ & [29] \\
\hline $\begin{array}{l}\text { EOs and functional extracts of cumin } \\
\text { and clove. }\end{array}$ & $\begin{array}{l}\text { E. coli, S. typhimurium, S. aureus, B. cereus, } \\
\text { L. monocytogenes }\end{array}$ & $\begin{array}{l}\text { The films of low molecular weight chitosan with a concentration } \\
\text { of } 2 \% \text { of EO of clove and clove ethyl heptanoate extract had } \\
\text { antimicrobial activities against most strains tested. }\end{array}$ & [30] \\
\hline $\begin{array}{l}\text { EOs and functional extracts of cumin, } \\
\text { clove, and elecampane }\end{array}$ & $\begin{array}{l}\text { E. coli, S. typhimurium, B. cereus, S. aureus, } \\
\text { L. monocytogenes }\end{array}$ & $\begin{array}{l}\text { Chitosan films added with clove EO showed the best inhibitory } \\
\text { effects with the MICs of } 500 \mathrm{mg} / \mathrm{L} \text {. }\end{array}$ & [31] \\
\hline 3 spice EOs & $\begin{array}{l}\text { Enterobacteriaceae, S. aureus, Pseudomonas sp., Lactic acid } \\
\text { bacteria, Brocithrix thermosphacta }\end{array}$ & Clove EO was the most effective against microorganisms tested. & [32] \\
\hline
\end{tabular}




\section{Oregano}

Oregano (Origanum vulgare), belonging to family Lamiaceae, has been used as food seasoning and flavoring for a long time. The major components associated with antimicrobial activities in oregano EO were proved to be carvacrol and thymol [33].

\subsection{Antimicrobial Activities of Oregano}

Babacan et al. [34] evaluated the antimicrobial activities of oregano extract against various Salmonella serotypes by evaluating the bacterial growth with disc diffusion method. The results showed that DIZs of oregano were 15, 19, and $16 \mathrm{~mm}$ for Salmonella gallinarum (S. gallinarum), Salmonella enteritidis (S. enteritidis), and S. typhimurium, respectively. Santoyo et al. [35] observed the antimicrobial activities of EO-rich fractions of oregano which were selectively precipitated in the second separator in different conditions against six microorganism strains (S. aureus, Bacillus subtilis (B. subtilis), E. coli, P. aeruginosa, C. albicans, and Aspergillus niger (A. niger)), using the disk diffusion and broth dilution methods. The results showed that all of the supercritical fluid extraction fractions exhibited antimicrobial effects on tested microorganisms, and the most efficient fraction was obtained with $7 \%$ ethanol at 150 bar and $40{ }^{\circ} \mathrm{C}$. De Souza et al. [36] evaluated the effects of heating (at the temperatures of $60,80,100$, and $120^{\circ} \mathrm{C}$, at a duration of $1 \mathrm{~h}$ for each) on the antimicrobial activities of oregano EO against 9 microorganism strains (C. albicans, Candida krusei (C. krusei), Candida tropicalis (C. tropicalis), B. cereus, E. coli, S. aureus, Yersinia enterocolitica (Y. enterocolitica), S. enterica, and Serratia marcescens (S. marcescens)), using the solid medium diffusion procedure. The results indicated that heating treatment showed no significant effects on the antimicrobial activities of EO, with the DIZs and MICs of heated EO close to those of EO kept at room temperature (MICs ranging from 10 to $40 \mu \mathrm{L} / \mathrm{mL}$ ).

Oregano could bind to sterols in the fungal membranes of $C$. albicans strains [37], but the exact mechanisms of action on other microorganisms are to be further studied. Carvacrol, one of the major components of oregano, could interact with cell membranes through changing the permeability for small cations [38]. As the chemical compounds in EO and extracts of oregano are complex, they could inhibit microorganisms through different cell targets.

\subsection{Comparison of Antimicrobial Activities of Oregano and Other Spices}

Ozcan et al. [39] investigated the antifungal activities of four spice decoctions against six molds (Fusarium oxysporum f. sp. phaseoli, Macrophomina phaseoli (M. phaseoli), Botrytis cinerea (B. cinerea), Rhizoctonia solani (R. solani), Alternaria solani (A. solani), and Alternaria parasiticus (A. parasiticus)). The results showed that the mycelial growth were $100 \%$ inhibited by $10 \%$ oregano decoction in culture medium. Ai-Turki et al. [40] tested the antimicrobial activities of aqueous extracts of four plants against E. coli and B. subtilis using the disc diffusion method. Oregano extract showed the best antibacterial effects on two bacteria compared with three other spice extracts, and B. subtilis showed more sensitivity than E. coli. Marques et al. [41] assessed the antimicrobial activities of the EOs of oregano and marjoram against $S$. aureus isolated from poultry meat using the disk diffusion method, and the MICs and MBCs were tested using the microdilution technique. All the $S$. aureus strains were susceptible to oregano EO with the MICs ranging from 6.25 to $25 \mu \mathrm{L} / \mathrm{mL}$, but four of the isolates were resistant to ampicillin and one was resistant to tetracycline. Bozin et al. [42] investigated the antimicrobial activities of 3 spice EOs against 13 bacterial strains using the hole-plate agar diffusion method and 6 fungi by the microdilution technique. The results indicated that the most effective antibacterial activities were expressed by oregano EO, even on multiresistant strains of P. aeruginosa and E. coli. Viuda-Martos et al. [43] studied the antimicrobial activities of EOs from six spices against six bacteria (Lactobacillus curvatus (L. curvatus), Lactobacillus sakei (L. sakei), Staphylococcus carnosus (S. carnosus), Staphylococcus xylosus (S. xylosus), Enterobacter gergoviae (E. gergoviae) and Enterobacter amnigenus (E. amnigenus)), using the disc diffusion method. Oregano EO was the most effective against bacteria tested, with DIZs ranging from $35.29 \mathrm{~mm}$ (S. xylosus) to $57.90 \mathrm{~mm}$ (E. amnigenus). Santurio et al. [44] reported the antimicrobial activities of 
EOs of eight spices against $E$. coli strains isolated from poultry and cattle faeces by determining the MICs using the broth microdilution technique. The results showed that the most effective against all E. coli strains in the study was oregano EO. Khosravi et al. [45] investigated the antifungal activities of Artemisia sieberi and oregano EOs against Candida glabrata (C. glabrata) isolated from patients with vulvovaginal candidiasis by determining the MICs and minimal fungicidal concentrations (MFCs), using the broth macrodilution method. The results indicated that the EOs inhibited all tested C. glabrata isolates concentration-dependently, with the MICs ranging from 0.5 to $1100 \mu \mathrm{g} / \mathrm{mL}$ (mean: 340.2 $\mu \mathrm{g} / \mathrm{mL}$ ) for oregano. Dal Pozzo et al. [46] studied the antimicrobial activities of 7 spice EOs, and some majority constituents of these spices such as carvacrol, thymol, cinnamaldehyde, and cineole against 33 Staphylococcus spp. isolates from herds of dairy goats, by determining the MICs and MBCs using the broth microdilution method. Oregano and thyme possessed equally strong antimicrobial activities among EOs. Santos et al. [47] evaluated the antimicrobial activities of four spices against several bacteria like S. aureus and E. coli isolated from vongole and bacteria standard ATCC (American Type Culture Collection): E. coli, S. aureus, and Salmonella choleraesuis (S. choleraesuis), by determining the MICs using diffusion test. Oregano and clove EOs presented antimicrobial activities against all tested bacteria, but oregano presented larger DIZs of $26.7 \mathrm{~mm}$ (E. coli) and $29.3 \mathrm{~mm}$ (S. aureus). Hyun et al. [48] tested the antibacterial effects of various spice EOs including oregano on total mesophilic microorganisms in products (fresh leaf lettuce and radish sprouts) using the dipping method. One species of oregano (in the USA) EO showed the best effects on maintaining reduced levels of total mesophilic microorganisms in fresh leaf lettuce and radish sprouts compared with the control.

\subsection{The Application of Oregano as Antimicrobial Agents in Food Packaging}

The antimicrobial effects of pure EOs of four spices and chitosan-EOs films on L. monocytogenes and E. coli were evaluated in vitro by agar diffusion test [49]. The antimicrobial activities of EOs alone and incorporated in the films were similar following the order: oregano $>>$ coriander $>$ basil $>$ anise. When used in inoculated bologna samples at $10{ }^{\circ} \mathrm{C}$ and stored for five days, pure chitosan films led to $2 \log$ reduction of L. monocytogenes, 3.6-4 $\log$ reduction of L. monocytogenes, and $3 \log$ reduction of E. coli were observed in films incorporated with $1 \%$ and $2 \%$ oregano EO.

All the above studies are of good quality, and oregano showed strong antimicrobial activities against microorganism strains such as Staphylococcus spp. and S. aureus isolates with larger DIZs and lower MICs, MBCs, and MFCs compared with several other spices (Table 2). Future studies could focus on the application of oregano and its EO in food industry, and also the possible mode of action. 
Table 2. Antibacterial and antifungal activities of oregano.

\begin{tabular}{|c|c|c|c|}
\hline Type of Study & Bacteria and Fungi & Main Results & Reference \\
\hline Oregano extract & $\begin{array}{l}\text { Salmonella gallinarum, Salmonella enteritidis, } \\
\text { S. typhimurium }\end{array}$ & Oregano extract had antibacterial effects on Salmonella serotypes. & [34] \\
\hline EO-rich fractions of oregano & $\begin{array}{l}\text { S. aureus, B. subtilis, E. coli, } P \text {. aeruginosa, C. albicans, } \\
\text { Aspergillus niger }\end{array}$ & $\begin{array}{l}\text { All of the supercritical fluid extraction fractions showed } \\
\text { antimicrobial activities against all tested microorganisms. }\end{array}$ & [35] \\
\hline Oregano EO & $\begin{array}{l}\text { C. albicans, Candida krusei, Candida tropicalis, B. cereus, } \\
\text { E. coli, S. aureus, Yersinia enterocolitica, S. enterica, } \\
\text { Serratia marcescens }\end{array}$ & $\begin{array}{l}\text { Heating treatment showed no significant effects on the } \\
\text { antimicrobial activities of EO. }\end{array}$ & [36] \\
\hline 4 spice decoctions & $\begin{array}{l}\text { F. oxysporum f. sp. phaseoli, Macrophomina phaseoli, } \\
\text { Botrytis cinerea, Rhizoctonia solani, Alternaria solani, } \\
\text { Alternaria parasiticus }\end{array}$ & $\begin{array}{l}\text { The } 10 \% \text { level of oregano decoction was } 100 \% \text { inhibitive to } \\
\text { mycelial growth in the culture medium. }\end{array}$ & [39] \\
\hline 4 plant aqueous extracts & E. coli and B. subtilis & $\begin{array}{l}\text { Oregano extract had the highest antibacterial activities against all } \\
\text { tested bacteria. }\end{array}$ & [40] \\
\hline Oregano and marjoram EOs & S. aureus isolated from poultry meat. & All the isolates tested were sensitive to EO of oregano. & [41] \\
\hline 3 spice EOs & 13 bacterial strains and 6 fungi & Oregano EO showed the most effective antibacterial activities. & [42] \\
\hline 6 spice EOs & $\begin{array}{l}\text { Staphylococcus xylosus, Staphylococcus carnosus, } \\
\text { Lactobacillus sakei, Lactobacillus curvatus, Enterobacter } \\
\text { gergoviae, Enterobacter amnigenus }\end{array}$ & Oregano EO was the most effective. & [43] \\
\hline 8 spice EOs & E. coli strains isolated from poultry and cattle faeces. & Oregano EO was the most effective against E. coli. & [44] \\
\hline Oregano and A. sieberi EOs & $\begin{array}{l}\text { Candida glabrata isolated from patients with } \\
\text { vulvovaginal candidiasis. }\end{array}$ & $\begin{array}{l}\text { The MICs of oregano EO ranged from } 0.5 \text { to } 1100 \mu \mathrm{g} / \mathrm{mL} \text { for all } \\
\text { tested C. glabrata isolates. }\end{array}$ & [45] \\
\hline 7 spice EOs and the majority constituents & 33 Staphylococcus spp. isolates & $\begin{array}{l}\text { Oregano and thyme EOs possessed the equal and strongest } \\
\text { antimicrobial activities among EOs. }\end{array}$ & [46] \\
\hline 4 spice EOs & $\begin{array}{l}\text { S. aureus and E. coli isolated from vongole and bacteria } \\
\text { standard ATCC: E. coli, S. aureus, Salmonella choleraesuis }\end{array}$ & $\begin{array}{l}\text { Oregano presented antimicrobial activities against all tested } \\
\text { bacteria. }\end{array}$ & [47] \\
\hline Various spice EOs & Microorganisms in fresh leaf lettuce and radish sprouts. & $\begin{array}{l}\text { Oregano-2 (in the USA) oil was the most effective at maintaining } \\
\text { the reduced levels of total mesophilic microorganisms. }\end{array}$ & [48] \\
\hline $\begin{array}{l}\text { Pure EOs of } 4 \text { spices and chitosan-EOs } \\
\text { films }\end{array}$ & L. monocytogenes and E. coli & $\begin{array}{l}\text { Both oregano EO alone and incorporated in the films possessed } \\
\text { the best antimicrobial activities. }\end{array}$ & [49] \\
\hline
\end{tabular}




\section{Thyme}

Thyme (Thymus vulgaris), belonging to family Lamiaceae, is a subshrub native to the western Mediterranean region. Thyme is widely used as a spice to add special flavor to foods. In recent studies, thyme was found to possess efficient antimicrobial activities and was used in some foods to extend the shelf-life [50].

\subsection{Antimicrobial Activities of Thyme}

A study evaluated the antimicrobial activities of thyme EO against bacteria (B. subtilis, S. aureus, Staphylococcus epidermidis (S. epidermidis), P. aeruginosa, E. coli, and Mycobacterium smegmatis (M. smegmatis)) and fungal strains (C. albicans and Candida vaginalis) [51]. Thyme EO showed effective bactericidal and antifungal activities against tested microorganism strains with MICs ranging from 75 to $1100 \mu \mathrm{g} / \mathrm{mL}$ for bacteria, and from 80 to $97 \mu \mathrm{g} / \mathrm{mL}$ for fungi. In another study, EOs obtained from thyme harvested at four ontogenetic stages were tested for their antibacterial activities against nine strains of Gram-negative bacteria and six strains of Gram-positive bacteria using the bioimpedance method to test the bacteriostatic activities and plate counting technique to study the inhibitory effects by direct contact [52]. The results indicated that all the thyme EOs had significant bacteriostatic activities against the microorganisms tested. Furthermore, the antimicrobial activities of EOs of four Thymus species (T. vulgaris, T. serpyllum, T. pulegioides, and T. glabrescens) were determined by agar diffusion method [53]. T. vulgaris and T. serpyllum EOs were the most efficient as they inhibited all the tested bacteria (P. aeruginosa, Cronobacter sakazakii (C. sakazakii), L. innocua, and Streptococcus pyogenes (S. pyogenes)) and yeasts (C. albicans and Saccharomyces cerevisiae (S. cerevisiae)) both at original and half-diluted concentrations. P. aeruginosa, L. innocua, and S. pyogenes were highly and equally sensitive to the Thymus oils, while $C$. sakazakii exhibited limited sensitivity, and the sensitivity of the two yeast strains were similar to that of $C$. sakazakii, but S. cerevisiae was a little more sensitive than C. albicans.

The major active compound of thyme is thymol, which exerted its antimicrobial action through binding to membrane proteins by hydrophobic bonding and hydrogen bonding, and then changing the permeability of the membranes [20]. Thymol also decreased intracellular adenosine triphosphate (ATP) content of E. coli and increased extracellular ATP, which could disrupt the function of plasma membranes [54]. As thymol was proved to act differently against Gram-positive and Gram-negative bacteria [20], the exact mechanisms of antimicrobial action should be further studied.

\subsection{Comparison of Antimicrobial Activities of Thyme and Other Spices}

Al-Turki et al. [55] reported the antibacterial activities of thyme, peppermint, sage, black pepper and garlic hydrosols against $B$. subtilis and S. enteritidis, using the agar disk diffusion method. Thyme hydrosol demonstrated more significant inhibitory effects on B. subtilis and S. enteritidis than sage, peppermint, and black pepper hydrosols, with the mean DIZs $20 \mathrm{~mm}$ for B. subtilis and $15 \mathrm{~mm}$ for S. enteritidis. According to another study, the antimicrobial effects of the six plant hydrosols on S. aureus, E. coli, S. typhimurium, P. aerugenosa, and C. albicans were tested by determining the microbial growth zones on hydrosol agar plates and control agar plates [56]. The results showed that at $15 \%$ thyme hydrosol completely inhibited E. coli and S. typhimurium, but C. albicans was inactive to the tested hydrosols. Girova et al. [57] assessed the antimicrobial activities of five plant EOs against psychrotrophic microorganisms (P. fluorescens, Pseudomonas putida (P. putida), P. fragi, B. thermosphacta, and C. albicans) isolated from spoiled chilled meat products and some reference strains (P. fluorescens ATCC 17397, P. putida NBIMCC (National Bank for Industrial Microorganisms and Cell Cultures) 561, P. aeruginosa ATCC 9027, and C. albicans ATCC 10231) using the method of disc diffusion and serial broth dilution. The results indicated that the antimicrobial effects of the EOs were equal at $37{ }^{\circ} \mathrm{C}$ and $4{ }^{\circ} \mathrm{C}$. Thyme EO exhibited the highest antimicrobial activities with the MICs ranging from $0.05 \%$ to $0.8 \% w / v$. Hajlaoui et al. [58] observed the anti-Vibrio alginolyticus (V. alginolyticus) activities of five aromatic plant EOs using agar well diffusion test, and the MICs and MBCs were examined using the broth microdilution susceptibility method. Thyme EO was proved to be the most efficient against 13 
V. alginolyticus strains compared with 4 other EOs, with the MICs ranges of $0.078-0.31 \mathrm{mg} / \mathrm{mL}$ and MBCs ranges of 0.31-1.25 mg/mL. Also, Viuda-Martos et al. [59] assessed the growth inhibition of some indicators of spoilage bacteria strains (L. innocua, S. marcescens, and P. fluorescens) and the concentration effects of five spice EOs using the agar disc diffusion method. Only the EO of thyme showed inhibitive effects on all tested bacteria at all added doses $(100 \%, 50 \%, 25 \%, 12.5 \%$, and $5 \%)$. Aliakbarlu et al. [60] evaluated the antibacterial activities of EOs from thyme, Thymus kotschyanus, Ziziphora tenuior, and Ziziphora clinopodioides, against two Gram-positive bacteria (B. cereus and L. monocytogenes) and two Gram-negative bacteria (S. typhimurium and E. coli), using the agar disc diffusion and micro-well dilution assay. The EO of thyme showed the highest antibacterial activities, with the widest inhibition zones and the lowest MICs $(0.312-1.25 \mu \mathrm{L} / \mathrm{mL})$, and B. cereus was the most sensitive bacterium tested. Hyun et al. [48] investigated the antibacterial effects of several EOs on 18 pathogenic bacteria and 15 spoilage bacteria by agar disc diffusion test. The results showed that thyme-1 (T. vulgaris) EO and thyme-2 (T. vulgaris ct linalool) EO exerted the highest antibacterial activities against 18 pathogenic bacteria strains compared with other spices, except for P. aeruginosa. Thyme- $1 \mathrm{EO}$ also demonstrated the best antibacterial effects on spoilage bacteria. In addition, the antimicrobial effects of 17 spices and herbs against Shigella strains were tested in another study [61]. The MICs were determined by the agar dilution method with dried ground spices and herbs added to the broth and agar, and the results showed that MICs of thyme were $0.5-1 \% w / v$ for the Shigella strains. The study also used various combinations of temperatures $\left(12,22\right.$, and $\left.37^{\circ} \mathrm{C}\right), \mathrm{pH}$ values $(5.0,5.5$, and 6.0$)$, and $\mathrm{NaCl}$ concentrations $(1 \%, 2 \%, 3 \%$, and $4 \% w / v)$, and the inclusion or exclusion of thyme or basil at $1 \% w / v$ in a Mueller-Hinton agar model system to test the inhibitory effects of thyme and basil. In the presence of thyme, Shigella flexneri (S. flexneri) did not develop Colony-Forming Units (CFU) during the seven-day incubation period for 16 of the 18 tested combinations.

Some studies compared the antimicrobial activities of different extracts of thyme. Martins et al. [62] evaluated and compared the antimicrobial activities of the infusion, decoction, and hydroalcoholic extracts prepared from thyme against S. aureus, S. epidermidis, E. coli, Klebsiella spp., P. aeruginosa, Enterobacter aerogenes (E. aerogenes), Proteus vulgaris (P. vulgaris), and Enterobacter sakazakii (E. sakazakii) using the disc diffusion halo test. For Gram-positive species, thyme extracts only presented activity against $S$. epidermidis, and hydroalcoholic extract showed a lower antibacterial activity than decoction and infusion extracts, which showed the similar activities. For Gram-negative species, thyme extracts showed antimicrobial activities in the order of E. coli $>P$. vulgaris, P. aeruginosa $>$ E. aerogenes $=$ E. sakazakii; decoction and hydroalcoholic extracts had similar effects against the bacteria except $P$. aeruginosa, while the lowest activity was observed in infusion extracts. Moreover, the antifungal effects of thyme EO, hydrosol and propolis extracts on natural mycobiota on the surface of sucuk were evaluated [63]. The results showed that potassium sorbate $(15 \% w / v$, in water), thyme EO $(10 \mathrm{mg} / \mathrm{mL}$, in dimethyl sulfoxide), and propolis extract $(50 \mathrm{mg} / \mathrm{mL}$, in dimethyl sulfoxide) reduced by $4.88,2.45$, and $2.05 \log \mathrm{CFU} / \mathrm{g}$ in yeast-mold counting compared with sterile water, respectively.

Aman et al. [64] analyzed the polyphenolic fractions and oil fractions of oilseeds from 4 spices, including thyme, for their antimicrobial activities against 35 bacterial strains. The results showed that oil fractions of all spice oilseeds were more active than their polyphenolic fractions, and thyme oil fraction had the highest antibacterial activities compared with other spice oilseeds. Aznar et al. [65] studied the growth of Candida lusitaniae (C. lusitaniae) on different concentrations of nisin (0.1-3 mmol/L), thymol (0.02-1.5 mmol/L), carvacrol $(0.02-1 \mathrm{mmol} / \mathrm{L})$, or cymene $(0.02-3 \mathrm{mmol} / \mathrm{L})$ in broths $\left(\mathrm{pH}=5,25^{\circ} \mathrm{C}\right)$, and also evaluated the inhibitory activity of thymol against $C$. lusitaniae in tomato juice. Thymol, carvacrol, and cymene totally inhibited the yeast growth for more than 21 days at $25^{\circ} \mathrm{C}$ when the concentrations were higher than $1 \mathrm{mmol} / \mathrm{L}$. Compared with the control without thymol, the activity of thymol against $C$. lusitaniae in tomato juice was significant.

In conclusion, the results obtained from a number of investigations with good quality indicated that thyme possessed effective antimicrobial activities against several pathogenic and spoilage bacteria and fungi, like S. aureus and E. coli, with low MICs $(\leq 1100 \mu \mathrm{L} / \mathrm{mL})$ (Table 3). 
Table 3. Antibacterial and antifungal activities of thyme.

\begin{tabular}{|c|c|c|c|}
\hline Type of Samples & Tested Bacteria and Fungi & Main Results & Reference \\
\hline Thyme EO & $\begin{array}{l}\text { B. subtilis, S. aureus, Staphylococcus epidermidis, } \\
\text { P. aeruginosa, E. coli, Mycobacterium smegmatis, } \\
\text { C. albicans, Candida vaginalis }\end{array}$ & $\begin{array}{l}\text { MICs ranged from } 75 \text { to } 1100 \mu \mathrm{g} / \mathrm{mL} \text { for bacteria, and from } 80 \text { to } \\
97 \mu \mathrm{g} / \mathrm{mL} \text { for fungi. }\end{array}$ & [51] \\
\hline Thyme EOs of 4 ontogenetic stages & $\begin{array}{l}\text { E. coli, Proteus mirabilis, Proteus vulgaris, S. typhimurium, } \\
\text { S. marcescens, Y. enterocolitica, P. fluorescens, Pseudomonas } \\
\text { putida, Micrococcus spp., S. flava, S. aureus, Bacillus } \\
\text { licheniformis, Bacillus thuringiensis, L. innocua }\end{array}$ & $\begin{array}{l}\text { All the thyme EOs had significant antibacterial activities against } \\
\text { the microorganisms tested. }\end{array}$ & [52] \\
\hline 4 Thymus species EOs & $\begin{array}{l}\text { P. aeruginosa, Cronobacter sakazakii, L. innocua, } \\
\text { Streptococcus pyogenes, C.albicans, Saccharomyces cerevisiae }\end{array}$ & $\begin{array}{l}\text { Thyme EO was the most efficient on all the tested bacteria and } \\
\text { yeast both in original and half-diluted concentrations. }\end{array}$ & [53] \\
\hline 5 spice hydrosols & B. subtilis and S. enteritidis & $\begin{array}{l}\text { Thyme hydrosol was more effective than sage, peppermint, and } \\
\text { black pepper. }\end{array}$ & [55] \\
\hline 6 plant hydrosols & S. aureus, E. coli, S. typhimurium, P. aeruginosa, C. albicans & $\begin{array}{l}\text { 15\% hydrosol concentration of thyme completely inhibited E. coli } \\
\text { and S. typhimurium. }\end{array}$ & [56] \\
\hline 5 plant EOs & $\begin{array}{l}\text { P. fluorescens, P. putida, Pseudomonas fragi, } \\
\text { Brochothrix thermosphacta C. albicans, P. aeruginosa }\end{array}$ & $\begin{array}{l}\text { Thyme EO showed the highest antimicrobial activities with MICs } \\
\text { ranging from } 0.05 \% \text { to } 0.8 \% w / v \text {. }\end{array}$ & [57] \\
\hline 5 aromatic plant EOs & 13 Vibrio alginolyticus strains & $\begin{array}{l}\text { The MICs of thyme EO ranged from } 0.078 \text { to } 0.31 \mathrm{mg} / \mathrm{mL} \text {, and } \\
\text { MBCs ranged from } 0.31 \text { to } 1.25 \mathrm{mg} / \mathrm{mL} \text {. }\end{array}$ & [58] \\
\hline 5 spice EOs & L. innocua, S. marcescens, P. fluorescens & $\begin{array}{l}\text { Only the thyme EO showed inhibition effects on all tested } \\
\text { bacteria at all added doses. }\end{array}$ & [59] \\
\hline 4 spice EOs & B. cereus, L. monocytogenes, S. typhimurium, E. coli & MICs of thyme EO ranged from 0.312 to $1.25 \mu \mathrm{L} / \mathrm{mL}$. & [60] \\
\hline Various EOs & 18 pathogens and 15 spoilage bacteria & $\begin{array}{l}\text { Thyme EO showed the strongest antibacterial activities against } \\
\text { spoilage bacteria. }\end{array}$ & [48] \\
\hline 17 spices and herbs & Shigella sonnei and Shigella flexneri & $\begin{array}{l}\text { MICs of thyme ranged from } 0.5 \% \text { to } 1 \%(w / v) \text { depending on the } \\
\text { Shigella strains used. }\end{array}$ & [61] \\
\hline $\begin{array}{l}\text { Thyme infusion, decoction and } \\
\text { hydroalcoholic extracts }\end{array}$ & $\begin{array}{l}\text { S. aureus, S. epidermidis, E. coli, Klebsiella spp., } \\
\text { P. aeruginosa, Enterobacter aerogenes, P. vulgaris, } \\
\text { Enterobacter sakazakii }\end{array}$ & Decoction presented the most pronounced effects. & [62] \\
\hline $\begin{array}{l}\text { Thyme EO, hydrosol and propolis } \\
\text { extracts }\end{array}$ & Natural mycobiota on the surface of sucuk & $\begin{array}{l}\text { Thyme EO and propolis extract provided reductions of } 2.45 \text { and } \\
2.05 \log \text { CFU/g in yeast-mold counts respectively. }\end{array}$ & [63] \\
\hline $\begin{array}{l}\text { Polyphenolic fractions and oil fractions } \\
\text { from } 4 \text { spice oilseeds }\end{array}$ & 35 bacterial strains & $\begin{array}{l}\text { Thyme oil fraction had the highest antibacterial activities } \\
\text { comparing with other spices oilseeds. }\end{array}$ & [64] \\
\hline Thymol, nisin, carvacrol, cymene & Candida lusitaniae & $\begin{array}{l}\text { Thymol completely inhibited the yeast growth at concentrations } \\
\text { over } 1 \mathrm{mmol} / \mathrm{L} \text { for at least } 21 \text { days at } 25^{\circ} \mathrm{C} \text {. }\end{array}$ & [65] \\
\hline
\end{tabular}




\section{Cinnamon}

Cinnamon (Cinnamomum zeylanicum), belonging to family Lauraceae, is widely applied in savory dishes, pickles, and soups [66]. Cinnamaldehyde, cinnamyl acetate, and cinnamyl alcohol are the three main compounds of cinnamon [67]. Due to its antimicrobial activities, cinnamon is also used in cosmetics or food products [11], and also used as health-promoting agents to treat diseases like inflammation, gastrointestinal disorders, and urinary infections $[68,69]$.

\subsection{Antimicrobial Activities of Cinnamon}

The antimicrobial activities of cinnamon were evaluated in some studies. Gupta et al. [70] compared the antimicrobial activities of cinnamon extract (50\% ethanol) and EO against 10 bacteria and 7 fungi by the agar well diffusion method. Cinnamon EO was more effective than cinnamon extract against tested microorganisms, with the MICs ranging from $1.25 \%$ to $5 \% v / v$. Cinnamon EO exerted the strongest effect on B. cereus among bacteria, and Rhizomucor sp. among fungi. Cinnamon extract showed the highest activities against $B$. cereus among bacteria, and Penicillium sp. among fungi. Ceylan et al. [71] tested the antibacterial effects of cinnamon, sodium benzoate, potassium sorbate, and their combinations on E. coli at 8 and $25{ }^{\circ} \mathrm{C}$ in apple juice. The results showed that $0.3 \% \mathrm{w} / \mathrm{v}$ cinnamon provided $1.6 \log \mathrm{CFU} / \mathrm{mL}$ reduction on E. coli at $8{ }^{\circ} \mathrm{C}$ and $2.0 \log \mathrm{CFU} / \mathrm{mL}$ reduction at $25{ }^{\circ} \mathrm{C}$. Cinnamon had synergistic effects with sodium benzoate and potassium sorbate on E. coli at 8 and $25^{\circ} \mathrm{C}$. Recently, the anti-biofilm effects of cinnamon EO and liposome-encapsulated cinnamon EO on methicillin resistant $S$. aureus (MRSA) were evaluated in a study by scanning electron microscopy and laser scanning confocal microscopy analyses [72]. Cinnamon EO possessed effective antibacterial activity and prominent anti-biofilm activity against MRSA. In the presence of liposomes, the stability and the acting time of cinnamon EO were further improved.

The major component of cinnamon, cinnamaldehyde, possesses antimicrobial effects on microorganisms, as it inhibited cell wall biosynthesis, membrane function, and specific enzyme activities. More specific cellular targets of cinnamaldehyde are still required to be studied in detail [73].

\subsection{Comparison of Antimicrobial Activities of Cinnamon and Other Spices}

Mvuemba et al. [74] evaluated the inhibitory effects of aqueous extracts of four spices (cinnamon, ginger, nutmeg, and horseradish) on the growth of mycelial of various spoilage pathogens (A. niger, Fusarium sambucinum (F. sambucinum), Pythium sulcatum (P. sulcatum), and Rhizopus stolonifera (R. stolonifera)). At the concentration of $0.05 \mathrm{~g} / \mathrm{mL}$, cinnamon extract totally inhibited A. niger and P. sulcatum, while at the level of 0.10 and $0.15 \mathrm{~g} / \mathrm{mL} \mathrm{F}$. sambucinum and $R$. stolonifer were completely inhibited, respectively. Another study conducted by Wang et al. [75] tested the antibacterial effects of five plant aqueous extracts on five bacteria (S. aureus, Lactobacillus sp., B. thermosphacta, Pseudomonas spp., and E. coli) by the aerobic plate count method and disc diffusion. Cinnamon aqueous extract was the only one to inhibit all the tested microorganisms at the concentration of $1 \% w / v$. The inhibitory effects were stronger with the increase of extract concentrations from $1 \%$ to $5 \% w / v$. In the same way, the antimicrobial activities of the hydrosols of six spices (basil, clove, cardamom, cinnamon, mustard, and thyme) against five microorganisms (S. aureus, E. coli, S. typhimurium, P. aeruginosa, and C. albicans) were tested [56]. The inhibition percentage of cinnamon hydrosol was $10-33.8 \%$ at $5 \% \mathrm{v} / \mathrm{v}$ hydrosol, $10-66.5 \%$ at $10 \% v / v$ hydrosol, and $10-100 \%$ at $15 \% v / v$ hydrosol against microorganisms tested except $C$. albicans. Moreover, $S$. aureus was the most sensitive strain to cinnamon hydrosol, while P. aeruginosa was the least sensitive strain. Agaoglu et al. [76] examined the antimicrobial activities of diethyl ether extracts of six spices used in meat products against eight strains of bacteria (S. aureus, K. pneumoniae, P. aeruginosa, E. coli, Enterococcus faecalis (E. faecalis), M. smegmatis, Micrococcus luteus (M. luteus), and C. albicans), by the disc diffusion. Among all the spices tested, only cinnamon exerted inhibitory activities against all the tested microorganisms. S. aureus and C. albicans were the most sensitive to cinnamon, while E. coli was the least. Keskin et al. [27] investigated the antimicrobial 
effects of the ethyl acetate, acetone, and methanol extracts of 12 plant species on 8 bacterial and 2 fungi species using the disc assay. Cinnamon methanol extract exerted antimicrobial effects on all tested microorganisms, while the ethyl acetate extract showed inhibition against tested microorganisms except $P$. aeruginosa and R. rubra, and the acetone extract showed inhibition against tested microorganisms except R. rubra. Revati et al. [77] explored the antimicrobial activities of seven Indian spice ethanol extracts against Enterococci (including 215 enterococcal strains) isolated from human clinical samples with the agar well diffusion method. Crude ethanol extract of cinnamon was the most effective against all the clinical isolates of Enterococci, with the DIZs ranging from 31 to $34 \mathrm{~mm}$. Moreover, the antimicrobial activities of 8 spice EOs against 6 bacterial species and 10 fungal species were tested in a study using the disk diffusion assay and MICs were determined using the agar dilution test [78]. Cinnamon EO possessed the strongest inhibition effects on all tested microorganisms among all spices examined with the MICs ranges of $0.015-2.0 \mathrm{mg} / \mathrm{mL}$. Compared with bacteria, fungi were more sensitive to cinnamon EO.

Collectively, all the mentioned studies with good quality demonstrated that cinnamon showed antimicrobial activities covering a wide range of species, such as MRSA and A. niger, at low MICs (Table 4), indicating that cinnamon had great potential to provide health benefits through application in food industry. 
Table 4. Antibacterial and antifungal activities of cinnamon

\begin{tabular}{|c|c|c|c|}
\hline Type of Samples & Tested Bacteria and Fungi & Mian Results & Reference \\
\hline Cinnamon extract and oil & $\begin{array}{l}7 \text { Gram-positive bacteria, } 3 \text { Gram-negative bacteria, and } \\
7 \text { fungi }\end{array}$ & $\begin{array}{l}\text { Cinnamon oil was more effective than cinnamon extract with } \\
\text { MICs ranging from } 1.25 \% \text { to } 5 \% v / v \text {. }\end{array}$ & [70] \\
\hline $\begin{array}{l}\text { Cinnamon, sodium benzoate, potassium } \\
\text { sorbate }\end{array}$ & E. coli & $\begin{array}{l}\text { E. coli was reduced by } 1.6 \log \mathrm{CFU} / \mathrm{mL} \text { at } 8{ }^{\circ} \mathrm{C} \text { and } 2.0 \log \\
\mathrm{CFU} / \mathrm{mL} \text { at } 25^{\circ} \mathrm{C} \text { by } 0.3 \% \text { cinnamon. }\end{array}$ & [71] \\
\hline $\begin{array}{l}\text { Cinnamon oil and } \\
\text { liposome-encapsulated cinnamon oil }\end{array}$ & Methicillin resistant Staphylococcus aureus (MRSA) & $\begin{array}{l}\text { Cinnamon oil possessed effective antibacterial activity and } \\
\text { prominent anti-biofilm activity against MRSA. }\end{array}$ & [72] \\
\hline 4 spice aqueous extracts & $\begin{array}{l}\text { A. niger, Fusarium sambucinum, Pythium sulcatum, } \\
\text { Rhizopus stolonifer }\end{array}$ & $\begin{array}{l}0.05 \mathrm{~g} / \mathrm{mL} \text { of cinnamon extract completely inhibited } A . \text { niger and } \\
\text { P. sulcatum, } 0.10 \mathrm{~g} / \mathrm{mL} \text { of cinnamon extract completely inhibited } \\
\text { F. sambucinum. }\end{array}$ & [74] \\
\hline 5 plant aqueous extracts & $\begin{array}{l}\text { S. aureus, Lactobacillus sp., B. thermosphacta, } \\
\text { Pseudomonas spp., E. coli }\end{array}$ & $\begin{array}{l}\text { Cinnamon aqueous extract inhibited all the tested } \\
\text { microorganisms at the concentration of } 1 \% \text {. }\end{array}$ & [75] \\
\hline 6 spice hydrosols & S. aureus, E. coli, S. typhimurium, P. aeruginosa, C. albicans & $\begin{array}{l}\text { The percent inhibition ranged from } 10 \% \text { to } 33.8 \% \text { at } 5 \% \text { hydrosol } \\
\text { of cinnamon. }\end{array}$ & [56] \\
\hline 6 spice diethyl ether extracts & $\begin{array}{l}\text { S. aureus, K. pneumoniae, P. aeruginosa, E. coli, } \\
\text { Enterococcus faecalis, M. smegmatis, Micrococcus luteus, } \\
\text { C. albicans }\end{array}$ & $\begin{array}{l}\text { Cinnamon possessed inhibitory activities against all the tested } \\
\text { microorganisms. }\end{array}$ & [76] \\
\hline $\begin{array}{l}\text { Ethyl acetate, acetone, and methanol } \\
\text { extracts from } 12 \text { plants }\end{array}$ & $\begin{array}{l}\text { K. pneumonia, B. megaterium, P. aeruginosa, S. aureus, } \\
\text { E. coli, E. cloacae, C. xerosis, S. faecalis, K. marxianus, } \\
\text { R. rubra }\end{array}$ & $\begin{array}{l}\text { The methanol extract of cinnamon showed antibacterial activities } \\
\text { against all the microorganisms tested. }\end{array}$ & [27] \\
\hline 7 Indian spice ethanol extracts & 215 enterococcal strains & $\begin{array}{l}\text { Crude ethanol extract of cinnamon was the most effective against } \\
\text { all the clinical isolates. }\end{array}$ & [77] \\
\hline 8 spice EOs & $\begin{array}{l}\text { B. cereus, E. coli, L. monocytogenes, S. rissen, P. fluorescens, } \\
\text { S. aureus, Candida lipolytica, Hanseniaspora uvarum, } \\
\text { Pichia membranaefaciens, Rhodotorula glutinis, } \\
\text { Schizosaccharomyces pombe, Zygosaccharomyces rouxii, } \\
\text { A. flavus, Aspergillus versicolor, A. parasiticus, } \\
\text { Fusarium moniliforme }\end{array}$ & $\begin{array}{l}\text { Cinnamon EO possessed the strongest inhibition effects with the } \\
\text { MICs ranging from } 0.015 \text { to } 2.0 \mathrm{mg} / \mathrm{mL} \text {. }\end{array}$ & [78] \\
\hline 10 spice EOs & $\begin{array}{l}\text { B. cereus, B. subtilis, E. coli, K. pneumoniae, } \\
\text { L. monocytogenes, P. aeruginosa, S. aureus, S. enterica, } \\
\text { S. marcencens, Y. enterocolitica }\end{array}$ & $\begin{array}{l}\text { Cinnamon EO was efficient in inhibiting all tested } \\
\text { bacterial strains. }\end{array}$ & [79] \\
\hline
\end{tabular}




\section{Cumin}

Cumin (Cuminum cyminum) is an aromatic plant belonging to the Apiaceae family. Cumin has been used since ancient time as an ingredient in foods in Middle East, and cumin seeds have long been used as antiseptic and disinfectant in India [80]. Cuminaldehyde, cymene, and terpenoids are the major bioactive constituents of cumin EOs [81].

\subsection{Antimicrobial Activities of Cumin}

In a study, the antimicrobial activities of cumin EO against E. coli, S. aureus, S. faecalis, P. aeruginosa, and K. pneumoniae were investigated by agar diffusion and dilution methods [81]. E. coli, S. aureus, and $S$. faecalis were susceptive to various cumin EO dilutions while P. aeruginosa and K. pneumoniae were resistant. In another study, the antifungal activities of cumin seeds EO against 1230 fungi isolated from food samples were tested [82]. The EO was fungicidal to most of the fungal species, and exerted a broad spectrum of fungal toxicity at MIC $(0.6 \mu \mathrm{L} / \mathrm{mL})$ against all 19 foodborne fungi strains except R. stolonifer. Furthermore, Abd El Mageed et al. [83] explored the effects of microwaves on EO of cumin seeds on its antimicrobial activities against E. coli, S. aureus, P. aeruginosa, A. niger, A. parasiticus, and C. albicans using the disk diffusion method. Both microwave and conventionally (oven) roasted cumin oils had similar antimicrobial effects on microorganisms tested and were more effective than those of raw oils. Reza et al. [80] studied the effects of ã-irradiation (10 and $25 \mathrm{kGy}$ ) on the antibacterial activities of cumin against E. coli, P. aeruginosa, B. cereus, and S. aureus, by the agar well diffusion method and disk diffusion method. The results indicated that cumin EO exerted antibacterial effects on bacteria tested, and ã-irradiation (10 and $25 \mathrm{kGy}$ ) to cumin seeds had no significant effects on the antimicrobial activities of cumin.

\subsection{Comparison of Antimicrobial Activities of Cumin and Other Spices}

Chaudhry et al. [84] determined the antibacterial effects of aqueous infusions and aqueous decoctions of 3 spices on 188 bacteria from 11 genera isolated from oral cavity of apparently healthy individuals, by the disc diffusion test. Aqueous decoction of cumin possessed the highest antimicrobial activities for it showed inhibitory effects on $73 \%$ of the bacteria strains tested. Cumin EO was also more effective than some spice EOs as reported. Iacobellis et al. [85] evaluated the antimicrobial activities of EOs of cumin and Carum carvi L. against E. coli and the genera Pseudomonas, Clavibacter, Curtobacterium, Rhodococcus, Erwinia, Xanthomonas, Ralstonia, and Agrobacterium using the agar diffusion test. Cumin EO showed antibacterial effects on both Gram-positive and Gram-negative bacteria except Pseudomonas viridiflava, which was resistant to $8 \mu \mathrm{L}$ EO, the highest level tested. Ozcan et al. [86] examined the antimicrobial activities of nine spice EOs at three concentrations $(1 \%, 10 \%$, and $15 \% \mathrm{v} / \mathrm{v})$ against $S$. typhimurium, B. cereus, S. aureus, E. faecalis, E. coli. Y. enterocolitica, S. cerevisiae, Candida rugosa, Rhizopus oryzae, and A. niger. The results showed that cumin EO was effective against all tested bacterial species as well as $S$. cerevisiae and Candida rugosa among fungi. Stefanini et al. [87] analyzed the antimicrobial activities of EOs of spices (fennel seeds, dill, cumin, and coriander) by determining the DIZs. The results indicated that cumin was effective against E. coli, P. aeruginosa, and Salmonella sp. with DIZs of 18, 10, and $23 \mathrm{~mm}$, respectively. In another study, the antimicrobial activities of EOs of six spices against L. curvatus, L. sakei, S. carnosus, S. xylosus, E. gergoviae, and E. amnigenus were assessed using the agar disc diffusion method [43]. Cumin EO was the second effective against bacteria tested with DIZs ranging from $31.23 \mathrm{~mm}$ (L. sakei) to $38.17 \mathrm{~mm}$ (E. gergoviae). Moreover, another study evaluated the antimicrobial activities of EOs of five spices against different microorganism species by the disc diffusion method and discussed the possible effects in vitro between plants and antibiotics [88]. Cumin inhibited all tested bacteria and fungi. The application of cumin with gentamicin, cephalothin, and ceftriaxone showed synergistic effects against Pseudomonas pyocyaneus (P. pyocyaneus) and Aeromonas hydrophila (A. hydrophila), but showed antagonistic effects against other bacteria tested. Similarly, the possible synergistic interactions of some spice EOs on antibacterial 
activities against six foodborne bacteria-B. cereus, L. monocytogenes, M. luteus, S. aureus, E. coli, and S. typhimurium - were evaluated by micro broth dilution, checkerboard titration, and time-kill methods [89]. The results showed that coriander and cumin seed oil combination exhibited synergistic interactions on antibacterial activities.

Consequently, cumin had antimicrobial effects on several microorganisms like E. coli, S. aureus, and S. faecalis at low concentrations (Table 5). In the future, the mechanisms of antimicrobial action of cumin and its major components—cuminaldehyde and cymene- on other microorganisms should be further studied. 
Table 5. Antibacterial and antifungal activities of cumin.

\begin{tabular}{|c|c|c|c|}
\hline Type of Study & Bacteria and Fungi & Main Results & Reference \\
\hline Cumin EO & E. coli, S. aureus, S. faecalis, P. aeruginosa, K. pneumoniae & $\begin{array}{l}\text { E. coli, S. aureus, and S. faecalis were sensitive to various cumin } \\
\text { EO dilutions. }\end{array}$ & [81] \\
\hline Cumin seeds EO & 1230 fungal isolates obtained from food samples & $\begin{array}{l}\text { The EO was fungicidal against most of the fungal species at MIC } \\
\text { of } 0.6 \mu \mathrm{L} / \mathrm{mL} \text {. }\end{array}$ & [82] \\
\hline Cumin seeds EOs & $\begin{array}{l}\text { E. coli, S. aureus, } P \text {. aeruginosa, A. niger, A. parasiticus, } \\
\text { C. albicans }\end{array}$ & $\begin{array}{l}\text { Both microwave and conventionally (oven) roasted cumin oils } \\
\text { showed higher effects than raw oils. }\end{array}$ & [83] \\
\hline Cumin EO & E. coli, P. aeruginosa, B. cereus, S. aureus & $\begin{array}{l}\text { ã-Irradiation to cumin seeds at } 10 \text { and } 25 \mathrm{kGy} \text { had no significant } \\
\text { effects on the antibacterial effects. }\end{array}$ & [80] \\
\hline $\begin{array}{l}\text { Aqueous infusions and aqueous } \\
\text { decoctions from kalonji, cumin and } \\
\text { poppy seed }\end{array}$ & $\begin{array}{l}188 \text { bacterial isolates isolated from oral cavity of } \\
\text { apparently healthy individuals }\end{array}$ & Aqueous decoction of cumin inhibited 73\% of the tested bacteria. & [84] \\
\hline Cumin and C. carvi EOs & $\begin{array}{l}\text { E. coli, the genera Pseudomonas, Clavibacter, } \\
\text { Curtobacterium, Rhodococcus, Erwinia, Xanthomonas, } \\
\text { Ralstonia, Agrobacterium }\end{array}$ & $\begin{array}{l}\text { Cumin EO showed antibacterial activities against all tested } \\
\text { bacteria except Pseudomonas viridiflava. }\end{array}$ & [85] \\
\hline 9 spice EOs & $\begin{array}{l}\text { S. typhimurium, B. cereus, S. aureus, E. faecalis, } \\
\text { E. coli. Y. enterocolitica, S. cerevisiae, Candida rugosa, } \\
\text { Rhizopus oryzae, A. niger }\end{array}$ & $\begin{array}{l}\text { Cumin EO was effective against all bacterial species and two } \\
\text { fungi (S. cerevisiae and Candida rugosa). }\end{array}$ & [86] \\
\hline 4 spice EOs & S. aureus, Salmonella sp., E. coli, P. aeruginosa, etc. & $\begin{array}{l}\text { Cumin EO was effective against E. coli, P. aeruginosa and } \\
\text { Salmonella sp. }\end{array}$ & [87] \\
\hline 6 spice EOs & $\begin{array}{l}\text { L. curvatus, L. sakei, S. carnosus, S. xylosus, E. gergoviae, } \\
\text { E. amnigenus }\end{array}$ & Cumin EO was the second effective among tested spices. & [43] \\
\hline 5 spice EOs & $\begin{array}{l}\text { M. luteus, B. megaterium, Brevibacillus brevis, E. faecalis, } \\
\text { Pseudomonas pyocyaneus, M. smegmatis, E. coli, Aeromonas } \\
\text { hydrophila, Y. enterocolitica, S. aureus, S. faecalis, } \\
\text { S. cerevisiae, Kluvyeromyces fragilis }\end{array}$ & $\begin{array}{l}\text { Cumin inhibited all tested bacteria and fungi and showed } \\
\text { synergistic and antagonistic effect with antibiotics. }\end{array}$ & [88] \\
\hline EOs of 9 spices in combination & $\begin{array}{l}\text { B. cereus, L. monocytogenes, M. luteus, S. aureus, E. coli, } \\
\text { S. typhimurium }\end{array}$ & $\begin{array}{l}\text { Coriander/cumin seed oil combination showed synergistic } \\
\text { interactions on antibacterial activities. }\end{array}$ & [89] \\
\hline
\end{tabular}




\section{Rosemary}

Rosemary (Rosmarinus officinalis), belonging to the Lamiaceae family, is a perennial shrub with pleasant smell and grows all over the world. Rosemary has been used in pharmaceutical products and traditional medicine, and also used as a flavoring agent in food products due to its desirable flavor, antioxidant activities, and antimicrobial activities [90,91].

\subsection{Antimicrobial Activities of Rosemary}

Tavassoli et al. [91] reported rosemary EO suppressed Leuconostoc mesenteroides, Lactobacillus delbruekii, S. cerevisia, and C. krusei. The results indicated that rosemary EO showed higher inhibitory effects on bacteria (MICs: $0.5-1.5 \mathrm{mg} / \mathrm{mL}$ ) tested than on yeasts. Bozin et al. [92] identified the antimicrobial activities of EOs of rosemary and sage against 13 bacterial strains and 6 fungi by the microdilution technique. Compared with bifonazole, rosemary EO showed better antifungal activities especially against $C$. albicans, Trichophyton tonsurans (T. tonsurans), and Trichophyton rubrum at lower MICs (15.0-30.2 $\mu \mathrm{L})$. Rosemary EO also expressed important antibacterial activities on E. coli, S. typhimurium, S. enteritidis, and Shigella sonei. Weerakkody et al. [93] compared the antibacterial effects of extracts from seven spices and herbs on E. coli, S. typhimurium, L. monocytogenes, and S. aureus by the agar disc diffusion and broth dilution assay. The results of both methods indicated that hexane extract of rosemary exhibited significantly higher antibacterial activities than ethanol and water extracts against all bacteria tested except $S$. typhimurium with the MICs ranging from 1.25 to $5.0 \mathrm{mg} / \mathrm{mL}$.

\subsection{Comparison of Antimicrobial Activities of Rosemary and Other Spices}

Additionally, Krajcova et al. [94] observed the antimicrobial activities of five plant ethanol extracts against B. cereus, E. coli, P. aeruginosa, S. aureus, and L. monocytogenes using the dilution method and the description of growth curves of the tested bacteria. Rosemary extract was proved to be the most effective at all concentrations $(0.1 \%, 0.05 \%, 0.02 \%$, and $0.01 \% w / w)$. At the concentration of $0.01 \%$ $w / w$, rosemary extract only inhibited P. aeruginosa and E. coli, while the higher extract concentrations were effective against all other bacteria. Zhang et al. [95] examined the antimicrobial effects of 14 spice ethanol extracts and their mixtures on L. monocytogenes, E. coli, P. fluorescens, and L. sake using the well diffusion test. Individual extract of rosemary showed strong antimicrobial activities, and the combination of rosemary and liquorice extracts showed the best inhibitory effects on all tested microorganisms. Kozlowska et al. [96] tested the antimicrobial activities of aqueous extracts from 5 spices against 8 Gram-positive bacteria and 12 Gram-negative bacteria by the disc diffusion assay. Rosemary exhibited its inhibitory effects with a broader spectrum than the other four spices, as the MICs were $0.125-0.5 \mathrm{mg} / \mathrm{mL}$ for all the tested Gram-positive bacteria and $0.25-0.5 \mathrm{mg} / \mathrm{mL}$ for four Gram-negative bacteria. Weerakkody et al. [97] studied the antimicrobial activities of two extract combinations against $L$. monocytogenes and S. aureus and naturally spoilage microflora on instant shrimp stored for 16 days at 4 or $8{ }^{\circ} \mathrm{C}$. Both combinations (galangal, rosemary, and lemon; galangal and rosemary) significantly decreased the levels of aerobic bacteria and lactic acid bacteria, but showed no effects on L. monocytogenes or S. aureus. Azizkhani et al. [90] evaluated the antimicrobial effects of rosemary, mint, and a mixture of tocopherols against microorganisms from the sausages. The application of rosemary significantly inhibited the growth of microorganisms and the lowest microbial counts were obtained in samples containing both rosemary and mint, indicating the possible synergistic effects. Toroglu [88] evaluated the antimicrobial activities of five spice EOs by the disc diffusion method and discussed possible effects of plants and antibiotics. Rosemary had antimicrobial effects on all tested fungi and bacteria. The combination of rosemary EO and cephalothin antibiotics showed synergic effects on S. aureus, while the combination of rosemary EO and ceftriaxone antibiotics showed no effect.

Above all, the papers cited are of good quality and indicated that rosemary EO and extracts were found antimicrobial at low MICs against some bacteria and fungi, especially Gram-positive bacteria such as S. aureus (Table 6). Some studies indicated that rosemary showed synergic effects with some spices and antibiotics such as galangal and cephalothin. The mechanisms of antimicrobial action of both rosemary and its major components should be further studied. 
Table 6. Antibacterial and antifungal activities of rosemary.

\begin{tabular}{|c|c|c|c|}
\hline Type of Study & Bacteria and Fungi & Main Results & Reference \\
\hline Rosemary EO & $\begin{array}{l}\text { Leuconostoc mesenteroides, Lactobacillus delbruekii, } \\
\text { S. cerevisiae, C. krusei }\end{array}$ & $\begin{array}{l}\text { Rosemary EO showed higher effects against bacteria tested than } \\
\text { yeasts. }\end{array}$ & [91] \\
\hline Rosemary and sage EOs & $\begin{array}{l}\text { C. albicans, Trichophyton mentagrophytes, Trichophyton } \\
\text { tonsurans, Trichophyton rubrum, Epidermophyton } \\
\text { floccosum, Microsporum canis, P. aeruginosa, E. coli, } \\
\text { S. typhimurium, S. enteritidis, Shigella sonei, Micrococcus } \\
\text { flavus, Sarcina lutea, S. aureus, S. epidermidis, B. subtilis }\end{array}$ & $\begin{array}{l}\text { The EO of rosemary showed significant antifungal activities and } \\
\text { antibacterial activities. }\end{array}$ & [92] \\
\hline 7 spice and herb extracts & E. coli, S. typhimurium, L. monocytogenes, S. aureus & $\begin{array}{l}\text { The hexane extract of rosemary exhibited significantly higher } \\
\text { antibacterial activities than ethanol and water extracts. }\end{array}$ & [93] \\
\hline 5 plant ethanol extracts & B. cereus, E. coli, P. aeruginosa, S. aureus, L. monocytogenes & $\begin{array}{l}\text { Rosemary extract was the most effective against all the tested } \\
\text { microorganisms. }\end{array}$ & [94] \\
\hline $\begin{array}{l}14 \text { spice ethanol extracts and their } \\
\text { mixture }\end{array}$ & L. monocytogenes, E. coli, P.fluorescens, L. sake & $\begin{array}{l}\text { The mixture of rosemary and liquorice extracts was the most } \\
\text { effective against all tested bacteria. }\end{array}$ & [95] \\
\hline 5 spice aqueous extracts & 8 Gram-positive bacteria and 12 Gram-negative bacteria & $\begin{array}{l}\text { MICs ranged from } 0.125 \text { to } 0.5 \mathrm{mg} / \mathrm{mL} \text { for Gram-positive } \\
\text { bacteria and } 0.25-0.5 \mathrm{mg} / \mathrm{mL} \text { for Gram-negative bacteria. }\end{array}$ & [96] \\
\hline 2 spice and herb extract combinations & $\begin{array}{l}\text { L. monocytogenes, S. aureus and naturally present } \\
\text { spoilage microflora on cooked ready-to-eat shrimp } \\
\text { stored for } 16 \text { days at } 4 \text { or } 8{ }^{\circ} \mathrm{C}\end{array}$ & $\begin{array}{l}\text { Both combination of galangal, rosemary, and lemon and } \\
\text { combination of galangal and rosemary significantly reduced } \\
\text { levels of aerobic bacteria and lactic acid bacteria. }\end{array}$ & [97] \\
\hline $\begin{array}{l}\text { Rosemary, mint and a mixture of } \\
\text { tocopherols }\end{array}$ & Microorganisms from the sausages & $\begin{array}{l}\text { The addition of rosemary resulted in significant inhibition of } \\
\text { microbial growth and showed possible synergistic effects with } \\
\text { mint. }\end{array}$ & [90] \\
\hline 5 spice EOs & $\begin{array}{l}\text { M. luteus, B. megaterium, B. brevis, E. faecalis, } \\
\text { P. pyocyaneus, M. smegmatis, E. coli, A. hydrophila, } \\
\text { Y. enterocolitica, S. aureus, S. faecalis, S. cerevisiae, } \\
\text { K. fragilis }\end{array}$ & Rosemary EO showed synergic effects with cephalothin. & [88] \\
\hline
\end{tabular}




\section{Garlic}

Garlic (Allium sativum) belongs to the Liliaceae family [98]. The antimicrobial activities of garlic have been recognized for many years, and the active component was identified as allicin, a diallyl thiosulfinate (2-propenyl-2-propenethiol sulfonate) [99].

\subsection{Antimicrobial Activities of Garlic}

In a study, Sallam et al. [100] examined the antimicrobial effects of fresh garlic, garlic powder, and garlic oil on microorganisms in raw chicken sausage by aerobic plate count. Garlic materials showed antimicrobial activities in such an order: fresh garlic $>$ garlic powder $>$ garlic oil $>$ butylated hydroxyanisole. Another study also assessed the antimicrobial activities of dried garlic powders made by different drying methods against S. aureus, E. coli, S. typhimurium, B. cereus and a mixed lactic culture containing Lactobacillus delbrueckii subsp. bulgaricus and Streptococcus thermophilus [99]. Fresh garlic exhibited the highest activities followed by freeze-dried powder. The retaining of active components responsible for antimicrobial activities was mainly affected by both drying temperature and time.

Chopped garlic at concentrations from $0 \%$ to $10 \%$ were investigated for the antimicrobial effects in ground beef (stored at refrigerator and ambient temperatures) and raw meatballs (stored at room temperature) by determining the colony counts of total aerobic mesophilic bacteria, yeast, and molds at 2, 6, 12, and $24 \mathrm{~h}$ after storage [101]. The results indicated that chopped garlic delayed the growth of microorganisms in ground meat, which depended on the garlic concentrations. The addition of garlic ( $5 \%$ or $10 \%$ ) to the raw meatball mix reduced the microorganism counting, in terms of total aerobic mesophilic bacteria, yeast, and mold counts.

Garlic EO penetrated the cellular membranes and even the menbranes of organelles like mitochondria, damaged organelles, and resulted in the death of C. albicans [102]. Furthermore, garlic EO induced differential expression of several critical genes including those involved in oxidation-reduction processes, and cellular response to drugs and starvation.

\subsection{Comparison of Antimicrobial Activities of Garlic and Other Spices}

Some studies compared the antimicrobial activities of different spices. Indu et al. [103] studied the antimicrobial effects of 5 spice extracts on 20 serogroups of E. coli, 8 serotypes of Salmonella, L. monocytogenes and A. hydrophila using the agar well method and filter paper method. Garlic extract exhibited significant antibacterial activities at all concentrations $(100 \%, 75 \%, 50 \%$, and $25 \%)$ against all test microorganisms except $L$. monocytogenes, and the activity against $E$. coli was linearly dependent with concentration. Joe et al. [104] reported the antimicrobial effects of garlic, ginger, and pepper ethanol extracts on K. pneumoniae, S. aureus, M. morgani, C. albicans, E. coli, and P. vulgaris using the filter paper assay. Garlic extract exerted superior antibacterial activities at all concentrations (1000, 1500 , and $2000 \mathrm{ppm}$ ), especially against $P$. vulgaris and M. morgani, and the activities were a linear function of concentrations. Geremew et al. [105] examined the antimicrobial activities of six spice crude extracts (acetone, ethanol, and hexane extracts) against E. coli, S. aureus, S. flexneri, and Streptococcus pneumoniae by the agar well diffusion method. Garlic was the most effective against all tested pathogens except S. flexneri. Among different solvent extracts used, garlic acetone extract exhibited the highest antibacterial activities. Touba et al. [106] tested the antimicrobial activities of crude extracts of seven spices against three Roselle pathogens by poisoned food technique. The results indicated that the cold water extract of garlic exhibited good antifungal activities against all three tested fungi, and hot water extract of garlic showed the best antifungal activities. Nejad et al. [98] reported the antibacterial effect of garlic aqueous extract on S. aureus in hamburger. Samples treated with garlic aqueous extract were kept in refrigerator for one and two weeks, and were frozen for one, two, and three months, before being tested by the microbial counts. The first- and second-week samples were significantly reduced by all the 1, 2, and 3-mL extracts, which were added to $100 \mathrm{~g}$ hamburger samples, respectively, showing 2 and 3-mL extracts were more effective. In treatment of one, two, and three-month samples, 
the growth of S. aureus was significantly decreased by the 2 and 3-mL extracts. Al-Turki [55] explored the antimicrobial activities of five spice hydrosols (thyme, peppermint, sage, black pepper, and garlic) against $B$. subtilis and $S$. enteritidis using the agar disk diffusion method. Garlic hydrosol exhibited stronger antibacterial activities against B. subtilis and S. enteritidis compared with thyme, peppermint, sage, and black pepper hydrosols.

In conclusion, garlic showed great antimicrobial activities at low concentrations against several pathogenic microorganisms like E. coli and S. aureus (Table 7). Fresh garlic was found to possess higher antimicrobial activities than garlic powder and oil. 
Table 7. Antibacterial and antifungal activities of garlic.

\begin{tabular}{|c|c|c|c|}
\hline Type of Study & Bacteria and Fungi & Main Results & Reference \\
\hline Fresh garlic, garlic powder, garlic oil & Microorganisms in raw chicken sausage & $\begin{array}{l}\text { The order of antimicrobial activities were fresh garlic }>\text { garlic } \\
\text { powder }>\text { garlic oil }>\text { butylated hydroxyanisole. }\end{array}$ & [100] \\
\hline Garlic powder & $\begin{array}{l}\text { S. aureus, E. coli, S. typhimurium, B. cereus, and a mixed } \\
\text { lactic culture consisting of Lactobacillus delbrueckii subsp. } \\
\text { bulgaricus and Streptococcus thermophilus }\end{array}$ & $\begin{array}{l}\text { Fresh garlic produced the greatest inhibition followed by } \\
\text { freeze-dried powder. }\end{array}$ & [99] \\
\hline Chopped garlic & Microorganisms in ground beef and raw meatball & $\begin{array}{l}\text { Chopped garlic had slowing-down effects on microbiological } \\
\text { growth. }\end{array}$ & [101] \\
\hline 5 spice extracts & $\begin{array}{l}20 \text { serogroups of E. coli, } 8 \text { serotypes of Salmonella, } \\
\text { L. monocytogenes and A. hydrophila }\end{array}$ & $\begin{array}{l}\text { Garlic extract exhibited significant activities against } \\
\text { microorganisms except L. monocytogenes at all concentrations. }\end{array}$ & [103] \\
\hline 3 ethanol extracts & $\begin{array}{l}\text { K. pneumoniae, S. aureus, M. morganii, C. albicans, E. coli, } \\
\text { P. vulgaris }\end{array}$ & $\begin{array}{l}\text { Garlic extract exerted superior antibacterial activities at all } \\
\text { concentrations }\end{array}$ & [104] \\
\hline $\begin{array}{l}6 \text { spice crude ethanol, hexane and } \\
\text { acetone extracts }\end{array}$ & E. coli, S. aureus, S. flexneri, Streptococcus pneumoniae & $\begin{array}{l}\text { Garlic was the most effective against all the tested pathogens } \\
\text { except } S \text {. flexneri. }\end{array}$ & [105] \\
\hline 7 spice crude extracts & Phoma exigua, Fusarium nygamai, R. solani & $\begin{array}{l}\text { Cold water extract of garlic exhibited good antifungal activities } \\
\text { against all three tested fungi. }\end{array}$ & [106] \\
\hline Garlic aqueous extract & S. aureus & $\begin{array}{l}\text { The first and second week samples were significantly decreased } \\
\text { by all the } 1,2 \text {, and 3-mL garlic extracts. }\end{array}$ & [98] \\
\hline 5 spice hydrosols & B. subtilis and S. enteritidis & $\begin{array}{l}\text { Garlic hydrosols demonstrated stronger antibacterial activities } \\
\text { than other spices hydrosols. }\end{array}$ & [54] \\
\hline
\end{tabular}




\section{Ginger}

Ginger (Zingiber officinale), belonging to the family of Zingiberaceae [107], is widely used as an ingredient in food, pharmaceutical, cosmetic, and other industries. Some volatile compounds which are responsible for antimicrobial activities in ginger were á-pinene, borneol, camphene, and linalool [108].

\subsection{Antimicrobial Activities of Ginger}

Ginger was proved to possess antimicrobial activities in several studies. Singh et al. [109] determined the antifungal activities of EO and oleoresin of ginger against Aspergillus terrus, A. niger, Aspergillus flavus (A. flavus), Trichothecium roseum (T. roseum), Fusarium graminearum (F. graminearum), F. oxysporum, Fusarium oxysporum (F. monoliforme), and Curoularia palliscens, by food poison and inverted petri-plate technique. The results showed that the EO 100\% inhibited F. oxysporum, while the oleoresin $100 \%$ inhibited A. niger. Park et al. [107] compared the ethanol and $n$-hexane extracts of ginger and five ginger constituents against three anaerobic Gram-negative bacteria, Porphyromonas gingivalis (P. gingivalis), Porphyromonas endodontalis, and Prevotella intermedia. The results indicated that ginger extracts exhibited antibacterial activities against three tested bacteria. Two highly alkylated gingerols showed significant inhibition against the growth of these oral pathogens with the MICs ranging from 6 to $30 \mu \mathrm{g} / \mathrm{mL}$, and also killed the oral pathogens at a MBC range of $4-20 \mu \mathrm{g} / \mathrm{mL}$. Sa-Nguanpuag et al. [108] evaluated the in vitro and in vivo antimicrobial activities of ginger oils which were obtained by hydrodistillation and solvent extraction method. The results showed that the oils extracted by both methods possessed antimicrobial activities against B. subtilis, Bacillus nutto, P. aerugenosa, Rhodoturola sp., Samonella newport, S. enteritidis, and Fusarium sp.; except E. coli, Campylobactor coli, and Campylobactor jejuni (C. jejuni) in vitro. In the case of shredded green papaya, when the package was added with 5 and $10 \mu \mathrm{L}$ ginger oils the growth of microorganisms was inhibited well, while with $15 \mu \mathrm{L}$ ginger oil a reduction in growth rate was observed.

\subsection{Comparison of Antimicrobial Activities of Ginger and Other Spices}

Yoo et al. [110] investigated the antibacterial activities of EOs from ginger and mustard against Vibrio species at various temperatures. The results indicated that EOs from ginger and mustard could inhibit the growth of Vibrio parahaemolyticus and Vibrio vulnificus at $5{ }^{\circ} \mathrm{C}$ of storage. Indu et al. [103] tested the antibacterial activities of 5 spice extracts against 20 serogroups of E. coli, 8 serotypes of Salmonella, L. monocytogenes, and A. hydrophila by the agar well method and filter paper method. The results indicated that ginger extract possessed inhibitory effects on two serogroups of $E$. coli. Mvuemba et al. [74] assessed the antimicrobial activities of four spice water extracts against the mycelial growth of A. niger, F. sambucinum, P. sulcatum, or R. stolonifera. The results demonstrated that ginger extract significantly suppressed the mycelial growth of tested microorganisms, and P. sulcatum was $100 \%$ inhibited by $0.05 \mathrm{~g} / \mathrm{mL}$ of ginger extract. Touba et al. [106] tested the antifungal activities of crude extracts of seven spices made by cold water and hot water against Phoma exigua (P. exigua), Fusarium nygamai (F. nygamai), and R. solani by poisoned food technique. The results showed that hot water extracts from garlic and ginger possessed the best antifungal activities. Cold water extracts were commonly more effective than hot water extracts on tested pathogens. In another study, the antibacterial activities of 7 ethanol extracts of spices against 215 high levels gentamicin resistant enterococcal strains isolated from clinical samples were evaluated by the well diffusion method [77]. The results indicated that only cinnamon and ginger extracts were found to have activities against all the isolates, with the DIZs of ginger ranged from 27 to $30 \mathrm{~mm}$.

Collectively, ginger was proved to possess significant antimicrobial activities against some common microorganisms such as P. aerugenosa both in vivo and in vitro at low concentrations (Table 8). Ginger could also inhibit pathgens like $P$. gingivalis and enterococcal isolates with low MICs and MBCs. The exact mechanisms of action of ginger on bacteria and fungi were rarely studied and need futher exploration. 
Table 8. Antibacterial and antifungal activities of ginger.

\begin{tabular}{|c|c|c|c|}
\hline Type of Sample & Bacteria and Fungi & Main Results & Reference \\
\hline 3 spice extracts and EOs & $\begin{array}{l}5 \text { strains of L. monocytogenes, } 4 \text { strains of S. typhimurium } \\
\text { DT104 }\end{array}$ & Commercial EOs of ginger inhibited all L. monocytogenes at $\leq 0.6$ & [111] \\
\hline Ginger EO and oleoresin & $\begin{array}{l}\text { Aspergillus terrus, A. niger, A. flavus, Trichothecium } \\
\text { roseum, Fusarium graminearum, Fusarium oxysporum, } \\
\text { Fusarium monoliforme, Curvularia palliscens }\end{array}$ & $\begin{array}{l}\text { EO and oleoresin of ginger were } 100 \% \text { antifungal against } \\
\text { F. oxysporum and A. niger, respectively. }\end{array}$ & [109] \\
\hline Ginger ethanol and $n$-hexane extracts & $\begin{array}{l}\text { Porphyromonas gingivalis, Porphyromonas endodontalis, } \\
\text { Prevotella intermedia }\end{array}$ & $\begin{array}{l}\text { Only [10]-gingerol and [12]-gingerol effectively inhibited the } \\
\text { growth of tested bacteria at a MIC range of } 6-30 \mu \mathrm{g} / \mathrm{mL} \text {. }\end{array}$ & [107] \\
\hline $\begin{array}{l}\text { Ginger oil extracted by hydrodistillation } \\
\text { and solvent extraction method }\end{array}$ & $\begin{array}{l}\text { B. subtilis, Bacillus nutto, P. aerugenosa, Rhodoturola sp., } \\
\text { Samonella newport, S. enteritidis, Fusarium sp. }\end{array}$ & $\begin{array}{l}\text { Extracts obtained by both extraction methods inhibited listed } \\
\text { microorganisms. }\end{array}$ & [108] \\
\hline Ginger and mustard EOs & Vibrio species & $\begin{array}{l}\text { Ginger and mustard EOs inhibited the growth of Vibrio } \\
\text { parahaemolyticus and Vibrio vulnificus. }\end{array}$ & [110] \\
\hline 5 spice extracts & $\begin{array}{l}20 \text { serogroups of E. coli, } 8 \text { serotypes of Salmonella, } \\
\text { L. monocytogenes and A. hydrophila. }\end{array}$ & $\begin{array}{l}\text { Ginger extract possessed inhibitory effects on two serogroups of } \\
\text { E. coli. }\end{array}$ & [102] \\
\hline 4 spice water extracts & A. niger, F. sambucinum, P. sulcatum, R. stolonifera & $\begin{array}{l}\text { Ginger extract significantly inhibited the mycelial growth of } \\
\text { tested microorganisms. }\end{array}$ & [74] \\
\hline 7 spice crude extracts & P. exigua, F. nygamai, R. solani & $\begin{array}{l}\text { In the case of the hot water extracts, garlic and ginger showed } \\
\text { the best antifungal activities. }\end{array}$ & [106] \\
\hline 7 spice ethanol extracts & 215 enterococcal strains isolated from clinical samples & $\begin{array}{l}\text { Ginger was found to have antibacterial activities against all } \\
\text { the isolates. }\end{array}$ & [76] \\
\hline
\end{tabular}




\section{Basil}

Basil (Ocimum basilicum) is one of the oldest spices, which is widely used in the flavoring of confectionary, baked goods, condiments, etc. Basil oil was also used in perfumery, as well as in dental and oral products [112]. Basil is a natural spice which possesses antimicrobial activities as many studies have reported.

\subsection{Antimicrobial Activities of Basil}

In a study, the antimicrobial activities of EOs from aerial parts of basil (collected at full flowering stage during summer, autumn, winter, and spring) against S. aureus, E. coli, B. subtilis, and Pasteurella multocida, as well as pathogenic fungi A. niger, Mucor mucedo, Fusarium solani (F. solani), Botryodiplodia theobromae, and R. solani were assessed by the disc diffusion method and the MICs were determined by a microdilution broth susceptibility assay [113]. The results indicated that basil EOs possessed antimicrobial activities against all tested microorganisms. Antimicrobial activities of the EOs varied significantly as seasons changed, and EOs from winter and autumn crops exhibited greater antimicrobial activities. In another study, the antimicrobial activities of chloroform, acetone and 2 different concentrations of methanol extracts of basil against 10 bacteria and 4 yeasts were determined by the disc diffusion assay [114]. Methanol extracts provided inhibition zones on P. aeruginosa, Shigella sp., L. monocytogenes, S. aureus, and two strains of E. coli, but the chloroform and acetone extracts exhibited no effects. Kocic-Tanackov et al. [115] reported the antifungal effects of basil extract on Fusarium species (Fusarium oxysporum, Fusarium proliferatum, Fusarium subglutinans, and Fusarium verticillioides isolated from cakes), by the agar plate test. Basil extract showed significant activities against $F$. proliferatum and $F$. subglutinans at the concentration of 0.35 and $0.70 \% v / v$, but showed lower activities against other tested Fusarium species. Basil extract 100\% inhibited aerial mycelium of all tested Fusarium spp. at 1.50\% v/v. Beatovic et al. [116] investigated the antimicrobial activities of EOs of 12 basil cultivars against 8 bacterial species (B. cereus, Micrococcus flavus, S. aureus and E. faecalis, E. coli, P. aeruginosa, S. typhimurium, and L. monocytogenes) and 7 fungi (Aspergillus fumigatus (A. fumigatus), A. niger, Aspergillus versicolor (A. versicolor), Aspergillus ochraceus (A. ochraceus), Penicillium funiculosum, Penicillium ochrochloron, and Trichoderma viride) by a modified microdilution technique. All basil EOs tested showed significant antimicrobial activities, with MICs ranging from 0.009 to $23.48 \mu \mathrm{g} / \mathrm{mL}$ for bacteria and $0.08-5.00 \mu \mathrm{g} / \mathrm{mL}$ for fungi. All the EOs showed 100-fold higher antibacterial activities than ampicillin for some bacteria, and 10- to 100-fold higher antifungal activities than the commercial antifungal agents, e.g., ketoconazole and bifonazole.

\subsection{Comparison of Antimicrobial Activities of Basil and Other Spices}

El-Habib [117] investigated the antifungal activities of seven spice EOs against $A$. flavus and aflatoxin producted by $A$. flavus strain. The results showed that basil EO delayed the growth of A. flavus. At $150 \mu \mathrm{L} / 100 \mathrm{~mL}$, basil EO completely inhibited A. flavus, and effectively controlled the aflatoxin B1 production. Lomarat et al. [17] tested the antibacterial activities of eight EOs against M. morganii, a histidine decarboxylase producing bacteria, by microdilution assay. Basil EO possessed the antibacterial activity against M. morganii (MIC: $2.39 \mathrm{mg} / \mathrm{mL}, \mathrm{MBC}: 4.77 \mathrm{mg} / \mathrm{mL}$ ), and the active compound of basil oil was methyl chavicol.

Generally, basil has been proved to possess effects of inhibiting some microorganisms at low MICs especially fungi like A. flavus (Table 9), but the mechanisms of action have been rarely explored. Therefore, future studies are needed. 
Table 9. Antibacterial and antifungal activities of basil.

\begin{tabular}{|c|c|c|c|}
\hline Type of Samples & Bacteria and Fungi & Main Results & Reference \\
\hline EO from aerial parts of basil & $\begin{array}{l}\text { S. aureus, E. coli, B. subtilis, Pasteurella multocida, A. niger, } \\
\text { Mucor mucedo, F. solani, Botryodiplodia theobromae, } \\
\text { R. solani }\end{array}$ & All the tested microorganisms were sensitive to EOs of basil. & [113] \\
\hline $\begin{array}{l}\text { Chloroform, acetone and methanol } \\
\text { extracts of basil }\end{array}$ & $\begin{array}{l}\text { E. gallinarum, E. faecalis, B. subtilis, E. coli, Shigella sp., } \\
\text { S. pyogenes, S. aureus, L. monocytogenes, P. aeruginosa, } \\
\text { S. cerevisiae, C. albicans, C. crusei }\end{array}$ & $\begin{array}{l}\text { The methanol extract inhibited P. aeruginosa, Shigella sp., } \\
\text { L. monocytogenes, S. aureus, and two strains of E. coli. }\end{array}$ & [114] \\
\hline Basil extracts & $\begin{array}{l}\text { Fusarium oxysporum, Fusarium proliferatum, Fusarium } \\
\text { subglutinans, Fusarium verticillioides }\end{array}$ & $\begin{array}{l}\text { At the concentration of } 1.50 \% v / v \text {, basil extract completely } \\
\text { inhibited Fusarium spp. tested. }\end{array}$ & [115] \\
\hline EOs from 12 cumin cultivars & $\begin{array}{l}\text { B. cereus, M. flavus, S. aureus, E. faecalis, E. coli, } \\
\text { P. aeruginosa, S. typhimurium, L. monocytogenes, } 7 \text { fungi, } \\
\text { Aspergillus fumigatus, A. niger, A. versicolor, } \\
\text { Aspergillus ochraceus, Penicillium funiculosum, } \\
\text { Penicillium ochrochloron, Trichoderma viride }\end{array}$ & $\begin{array}{l}\text { MICs of basil EOs ranged from } 0.009 \text { to } 23.48 \mu \mathrm{g} / \mathrm{mL} \text { for bacteria } \\
\text { and } 0.08-5.00 \mu \mathrm{g} / \mathrm{mL} \text { for fungi. }\end{array}$ & [116] \\
\hline 7 spice EOs & A. flavus & Basil EO completely inhibited A. flavus at $150 \mu \mathrm{L} / 100 \mathrm{~mL}$. & [117] \\
\hline 8 spice EOs & Histamine-producing bacteria including $M$. morganii & Basil EO inhibited M. morganii with the MIC of $2.39 \mathrm{mg} / \mathrm{mL}$. & [17] \\
\hline
\end{tabular}




\section{Fennel}

Fennel (Foeniculum vulgare), belonging to family Umbellifarae [118], is widely planted in temperate zones and the tropical belt for its aromatic fruits, and is used as an ingredient in the cooking [119]. The EO of fennel seeds has been reported with significant antifungal activities and antibacterial activities.

\subsection{Antimicrobial Activities of Fennel}

In a study, the antibacterial activities of fennel seeds EO against Streptococcus mutans (S. mutans) strains were tested [120]. The results showed that growths of all S. mutans strains tested were completely inhibited by fennel seeds EOs at concentrations higher than $80 \mathrm{ppm}$. Diao et al. [119] also determined the antibacterial activities of EO from fennel seeds against several foodborne pathogens by the kill-time curve assay method. The results showed that fennel seeds EO exerted antibacterial effects on Streptomyces albus (S. albus), B. subtilis, S. typhimurium, Shigella dysenteriae (S. dysenteriae). and E. coli, among which $S$. dysenteriae was the most sensitive with the lowest MIC $(0.125 \mathrm{mg} / \mathrm{mL})$ and MBC $(0.25 \mathrm{mg} / \mathrm{mL})$. In another study, the antimicrobial activities of crude extract of fennel was determined using the agar diffusion method against E. coli, S. blanc, P. merabilis, P. vulgaris, S. epidemidis, S. saprophyticus, A. versicolor, A. fumigates, and Penicilium camemberti [121]. The results indicated that the crude extract of fennel had a great potential as an antimicrobial material against all the nine microorganisms tested, especially fungal strains. Some studies also tested the methanol, ethanol, and acetone extracts of fennel. In a study, the antifungal activities of EO and acetone extract of fennel against 10 fungi were assessed by the inverted petriplate method [118]. The results showed that fennel EO completely inhibited A. niger, A. flavus, F. graminearum, and Fusarium moniliforme (F. moniliforme) at $6 \mu \mathrm{L}$ (in $20 \mathrm{~mL}$ culture medium), and it was effective on $A$. niger even at $4 \mu \mathrm{L}$.

Fennel seed EO could break the permeability of cell membrane of $S$. dysenteriae and result in the leakage of electrolytes, losses of proteins, reducing sugars, etc., and eventually lead to the decomposition and death of cells [119].

\subsection{Comparison of Antimicrobial Activities of Fennel and Other Spices}

The antimicrobial activities of cumin and fennel EOs on S. typhimurium and E. coli were compared by the disc diffusion method and dilution method [122]. Fennel EO was more effective than cumin EO, with the lowest MICs of $0.031 \%$ and $0.062 \% v / v$ against S. typhimurium and E. coli, respectively. Nguyen et al. [123] evaluated the antimicrobial activities of methanol and ethanol extracts of eight spices against B. subtilis, E. faecalis, L. innocua, E. coli, P. putida, Providencia stuartii, and Acetobacter calcoaceticus (A. calcoaceticus) by the Kirby-Bauer disc diffusion method. Methanol and ethanol extracts from fennel seeds exhibited the best antimicrobial effects with the largest DIZs on six out of the seven bacteria except E. coli.

Fennel EO and extracts were effective against several foodborne pathogens with low MICs and MBCs such as S. dysenteriae, S. typhimurium, and E. coli (Table 10). The mechanisms of fennel and its major components need further studies. 
Table 10. Antibacterial and antifungal activities of fennel.

\begin{tabular}{|c|c|c|c|}
\hline Type of Sample & Bacteria and Fungi & Main Results & Reference \\
\hline Fennel seeds EO & Streptococcus mutans & MICs: 80 ppm & [120] \\
\hline Fennel seeds EO & $\begin{array}{l}\text { Streptomyces albus, B. subtilis, } S . \\
\text { typhimurium, P. aeruginosa, } \\
\text { Shigella dysenteriae, E. coli }\end{array}$ & $\begin{array}{l}\text { EO of fennel seeds inhibited } \\
\text { several foodborne pathogens with } \\
\text { lowest MIC of } 0.125 \mathrm{mg} / \mathrm{mL} \text {. }\end{array}$ & [119] \\
\hline Fennel crude extract & $\begin{array}{l}\text { E. coli, S. blanc, P. merabilis, } \\
\text { P. vulgaris, S. epidemidis, } \\
\text { Staphylococcus saprophyticus, } \\
\text { A. versicolor, A. fumigates, } \\
\text { Penicilium camemberti }\end{array}$ & $\begin{array}{l}\text { Fennel crude extract had } \\
\text { antimicrobial activities against all } \\
\text { nine microorganisms, especially } \\
\text { fungi. }\end{array}$ & [121] \\
\hline $\begin{array}{l}\text { Fennel EO and } \\
\text { acetone extract }\end{array}$ & $\begin{array}{l}\text { A. niger, A. flavus, Aspergillus oryzae, } \\
\text { A. ochraceus, F. graminearum, } \\
\text { F. moniliforme, P. ctrium, } \\
\text { Penicillium viridicatum, } \\
\text { Penicillium madriti, Curvularia lunata }\end{array}$ & $\begin{array}{l}\text { Fennel EO showed complete zone } \\
\text { inhibition against several strains } \\
\text { at } 6 \mu \mathrm{L} \text { dose. }\end{array}$ & [118] \\
\hline $\begin{array}{l}\text { Cumin and fennel } \\
\text { EOs }\end{array}$ & S. typhimurium and E. coli & $\begin{array}{l}\text { The MICs of fennel EO was } \\
0.031 \% v / v \text { against } S \text {. typhimurium } \\
\text { and } 0.062 \% v / v \text { E. coli. }\end{array}$ & [122] \\
\hline $\begin{array}{l}8 \text { spice methanol and } \\
\text { ethanol extracts }\end{array}$ & $\begin{array}{l}\text { B. subtilis, E. faecalis, L. innocua, } \\
\text { E. coli, P. putida, Providencia stuartii, } \\
\text { Acetobacter calcoaceticus }\end{array}$ & $\begin{array}{l}\text { Fennel seeds extracts showed the } \\
\text { largest zones of inhibitions in six } \\
\text { out of the seven bacteria. }\end{array}$ & [123] \\
\hline
\end{tabular}

\section{Coriander}

Coriander (Coriandrum sativum), belonging to family Umbelliferae, is a native plant of the Mediterranean region and is widely cultivated in India, Russia, Central Europe, Asia, and Morocco. Coriander was widely applied in producing chutneys and sauces, flavoring pastry, cookies, buns, and tobacco products, and extensively employed for preparation of curry powder, pickling spices, sausages, seasonings, and food preservatives $[4,118]$.

\subsection{Antimicrobial Activities of Coriander}

Duarte et al. [124] investigated the antimicrobial activities of coriander EO and its major compound, linalool, against $C$. jejuni and $C$. coli strains by the disc diffusion test, vapor-phase method and microdilution method. The MICs of coriander EO and linalool against C. jejuni and C. coli strains ranged between 0.5 and $1 \mu \mathrm{L} / \mathrm{mL}$. Coriander EO also showed inhibitory effects on the biofilim formation of Campylobacter spp. Also, the antimicrobial activities of coriander EO against multidrug resistant pathogen, Acinetobacter baumannii (A. baumannii), were tested [125]. The MICs and MBCs were determined by a microdilution broth susceptibility assay. The MICs and MBCs of coriander EO against A. baumannii strains both ranged between 1 and $4 \mu \mathrm{L} / \mathrm{mL}$. Another study investigated the synergistic antibacterial effects of coriander EO and six antibacterial drugs (cefoperazone, chloramphenicol, ciprofloxacin, gentamicin, tetracycline, and piperacillin) against two A. baumannii strains [126]. The results indicated that coriander EO showed synergistic action with chloramphenicol, ciprofloxacin, and tetracycline, and contributed to resensitizing A. baumannii to the action of chloramphenicol. Freires et al. [127] investigated the antifungal activities of EO from coriander leaves against Candida spp. The results showed that the MICs ranged from 15.6 to $31.2 \mu \mathrm{g} / \mathrm{mL}$, and MFCs ranged from 31.2 to $62.5 \mu \mathrm{g} / \mathrm{mL}$ against Candida spp. for coriander EO. Sliva et al. [128] assessed the bacterial activities of coriander EO against 12 bacterial strains by microdilution broth susceptibility assay. The results indicated that coriander EO showed antimicrobial activities against all tested bacteria and showed bactericidal activities against bacteria except $B$. cereus and E. faecalis. The MICs of coriander against all tested bacteria ranged from $0.1 \%$ to $1.6 \% v / v$, and MBCs ranged from $0.1 \%$ to $3.2 \% v / v$ except B. cereus and E. faecalis. Acimovic et al. [129] assessed the antifungal activities of EOs of six coriander 
accessions of different origins against Colletotrichum acutatum and Colletotrichum gloeosporioides using the inverted petriplate method. The results indicated that coriander EOs could inhibit Colletotrichum genus at higher application rates $(\geq 0.16 \mu \mathrm{L} / \mathrm{mL}$ of air).

Singh et al. [130] reported the antifungal effects of coriander EO and oleoresin on eight fungi by the inverted petriplate and food poison techniques. The results of the former method showed that EO was highly active against Curpularia palliscens, F. oxysporum, Fusarium monitiforme, and Aspergillus terreus (A. terreus), and the oleoresin inhibited more than $50 \%$ mycelial zones for F. oxysporum, A. niger, and $A$. terreus. The results of the latter method indicated that EO 100\% inhibited the growth of A. terreus, A. niger, F. graminearum, and F. oxysporum, but the oleoresin exhibited weaker fungitoxic activities, which only $100 \%$ inhibited the growth of F. oxysporum. In another study, the antimicrobial activities of ethanol and aqueous-ethanol extracts of coriander were investigated against B. subtilis, S. aureus, P. vulgaris, E. coil, P. aeruginosa, K. peunomonia, L. monocytogenes, and C. albicans [131]. Ethanol extract revealed the elevated antimicrobial activities against $P$. vulgaris and C. albicans, and was more potent against tested microorganisms. Besides, aqueous-ethanol extract exhibited the highest activities against B. subtilis and L. monocytogenes. Furthermore, the effect of microwaves on EO of coriander on its antimicrobial activities was also tested [83]. The antimicrobial effects against microorganisms of both microwave and conventionally roasted oils were similar and more effective than those of raw oils.

Coriander EO permeated the cell membranes, resulting in the loss of all cellular functions [4]. The mechanisms of antibacterial action of coriander EO on Gram-positive and Gram-negative bacteria are different and need further exploring. Coriander EO was found to bind to membrane ergosterol and increase ionic permeability, ultimately causing cell death of $C$. albicans [127].

\subsection{Comparison of Antimicrobial Activities of Coriander and Other Spices}

The antimicrobial activities of four spice EOs against isolated clinical specimens were compared using the diffusion method [87], and the results showed that coriander oil was active only against Salmonella sp. Dimic et al. [132] tested the antifungal activities of lemon EO, coriander extract and cinnamon extract against five molds (A. parasiticus, Cladosporium cladosporioides (C. cladosporioides), Eurotium herbariorum, Penicillium chrysogenum, and Aspergillus carbonarius) by the agar dilution method and vapor phase method. The results indicated that coriander extract had the best antifungal activities in the vapor phase as it completely inhibited A. parasiticus, C. cladosporioides, E. herbariorum, and P. chrysogenum at $4.17 \mu \mathrm{L} / \mathrm{mL}$.

The papers cited are of high quality and indicated that coriander possessed significant antimicrobial activities at low concentrations against several pathogens such as A. baumannii, Campylobacter spp. at low MICs, MBCs, and MFCs (Table 11). 
Table 11. Antibacterial and antifungal activities of coriander.

\begin{tabular}{|c|c|c|c|}
\hline Type of Sample & Bacteria and Fungi & Main Results & Reference \\
\hline Coriander EO and linalool & Campylobactor jejuni and Campylobactor coli strains & MICs ranged between 0.5 and $1 \mathrm{~mL} / \mathrm{mL}$. & [124] \\
\hline Coriander EO & A. baumannii strains & MICs and MBCs ranged between 1 and $4 \mu \mathrm{L} / \mathrm{mL}$. & [125] \\
\hline Coriander EO and 6 antibacterial drugs & A. baumannii strains & $\begin{array}{l}\text { Coriander EO showed synergistic action with chloramphenicol, } \\
\text { ciprofloxacin, and tetracycline. }\end{array}$ & [126] \\
\hline Coriander leaves EO & Candida spp. & $\begin{array}{l}\text { MICs ranged from } 15.6 \text { to } 31.2 \mu \mathrm{g} / \mathrm{mL} \text {, and MFCs ranged from } \\
31.2 \text { to } 62.5 \mu \mathrm{g} / \mathrm{mL} \text {. }\end{array}$ & [127] \\
\hline Coriander EO & 12 bacterial strians & $\begin{array}{l}\text { MICs of coriander against all tsted bacteria ranged from } 0.1 \% \text { to } \\
1.6 \%, v / v \text {. }\end{array}$ & [128] \\
\hline EOs of 6 coriander accessions & Colletotrichum acutatum and Colletotrichum gloeosporioides & $\begin{array}{l}\text { Coriander EOs could inhibit Colletotrichum genus at higher } \\
\text { application rates. }\end{array}$ & [129] \\
\hline Coriander EO and oleoresin & Aspergillus terreus, A. niger, F. graminearum, F. oxysporum & $\begin{array}{l}\text { Both EO and oleoresin of coriander were effective against tested } \\
\text { fungi. }\end{array}$ & [130] \\
\hline $\begin{array}{l}\text { Coriander ethanol and aqueous-ethanol } \\
\text { extracts }\end{array}$ & $\begin{array}{l}\text { B. subtilis, S. aureus, P. vulgaris, E. coil, P. aeruginosa, } \\
\text { K. peunomonia, L. monocytogenes, C. albicans }\end{array}$ & $\begin{array}{l}\text { The ethanol extract showed clear difference and more potent } \\
\text { against tested microorganisms in comparison with the } \\
\text { aqueous-ethanol extract. }\end{array}$ & [131] \\
\hline Coriander EO & - & $\begin{array}{l}\text { Microwave and conventionally roasted oils exhibit similar } \\
\text { antimicrobial effects but were higher effect than raw oils. }\end{array}$ & [83] \\
\hline 4 spice EOs & $\begin{array}{l}\text { Microorganisms isolated from clinical specimens of } \\
\text { patients }\end{array}$ & Coriander oil was active only against Salmonella sp. & [87] \\
\hline $\begin{array}{l}\text { Lemon EO, coriander extract and } \\
\text { cinnamon extract }\end{array}$ & $\begin{array}{l}\text { A. parasiticus, Cladosporium cladosporioides, } \\
\text { Eurotium herbariorum, Penicillium chrysogenum and } \\
\text { Aspergillus carbonarius }\end{array}$ & $\begin{array}{l}\text { Coriander extract had the best antifungal activities in the } \\
\text { vapor phase }\end{array}$ & [132] \\
\hline
\end{tabular}




\section{Galangal}

Galangal (Alpinia galangal) (Table 12) has been used as a food additive in Thailand and other Asian countries since ancient time [133]. In a study, the antimicrobial activities of extracts of seven spices and herbs against E. coli, S. typhimurium, L. monocytogenes, and S. aureus were compared by the agar disc diffusion and broth dilution assays [93]. The hexane and ethanol extracts of galangal had strong antimicrobial activities against S. aureus (MIC $<0.625 \mathrm{mg} / \mathrm{mL}$ ) and L. monocytogenes (MIC $<0.625 \mathrm{mg} / \mathrm{mL}$ at $24 \mathrm{~h}$ and $1.25 \mathrm{mg} / \mathrm{mL}$ at $48 \mathrm{~h}$ ). Moreover, the synergistic antimicrobial effects of extract combination (galangal, rosemary, and lemon iron bark) on S. aureus, L. monocytogenes, E. coli, S. typhimurium, and Clostridium perfringens were evaluated [134]. Galangal and rosemary showed synergistic activities against $S$. aureus and L. monocytogenes, while galangal and lemon iron bark showed synergistic activities against E. coli and S. typhimurium. Additionally, Rao et al. [133] tested the antibacterial activities of galangal methanol, acetone, and diethyl ether extracts against B. subtilis, E. aerogenes, E. cloacae, E. faecalis, E. coli, K. pneumoniae, P. aeruginosa, S. typhimurium, S. aureus, and S. epidermis using agar well diffusion method and macrodilution method. Among the three solvents used, the activities of methanol extract at $\mathrm{pH} 5.5$ were excellent against all the pathogens (MIC: 0.04-1.28 mg/mL, MBCs: 0.08-2.56 mg/mL). Another study also evaluated the antimicrobial activities of methanol extracts of four Alpinia strains against six strains of bacteria and four strains of fungi, using the disc diffusion assay [135]. The results demonstrated that galangal flower possessed the best effects on $M$. luteus and only the extract from galangal rhizome showed antifungal activity toward A. niger. The mechanisms of action of galangal have been rarely explored up till now.

Table 12. Antibacterial and antifungal activities of galangal.

\begin{tabular}{llll}
\hline \multicolumn{1}{c}{ Type of Sample } & \multicolumn{1}{c}{ Bacteria and Fungi } & \multicolumn{1}{c}{ Main Results } & Reference \\
\hline $\begin{array}{l}7 \text { spice and herb } \\
\text { extracts }\end{array}$ & $\begin{array}{l}\text { E. coli, S. typhimurium, } \\
\text { L. monocytogenes, S. aureus }\end{array}$ & $\begin{array}{l}\text { Galangal hexane and ethanol } \\
\text { extracts had strong antimicrobial } \\
\text { activities against S. aureus and } \\
\text { L. monocytogenes. }\end{array}$ & [93] \\
\hline $\begin{array}{l}\text { Combination of } \\
\text { extracts from } \\
\text { galangal, rosemary } \\
\text { and lemon iron bark }\end{array}$ & $\begin{array}{l}\text { S. aureus, L. monocytogenes, E. coli, } \\
\text { S.typhimurium, Clostridium }\end{array}$ & $\begin{array}{l}\text { Galangal showed synergistic } \\
\text { activities against tested } \\
\text { microorganisms with rosemary } \\
\text { and lemon iron bark. }\end{array}$ & [134] \\
\hline $\begin{array}{l}\text { Galangal methanol, } \\
\text { acetone and diethyl } \\
\text { ether extracts }\end{array}$ & $\begin{array}{l}\text { B. subtilis, E. aerogenes, E. cloacae, } \\
\text { E. faecalis, E. coli, K. pneumoniae, } \\
\text { P. aeruginosa, S. typhimurium, } \\
\text { S. aureus, S. epidermis }\end{array}$ & $\begin{array}{l}\text { The activities of methanol extract } \\
\text { at pH 5.5 were excellent with } \\
\text { MICs ranging from 0.04 to } \\
1.28 \text { mg/mL. }\end{array}$ & [133] \\
\hline $\begin{array}{l}\text { Alpinia strains } \\
\text { methanol extracts }\end{array}$ & $\begin{array}{l}\text { 6 strains of bacteria and 4 strains } \\
\text { of fungi }\end{array}$ & $\begin{array}{l}\text { Galangal flower possessed the } \\
\text { highest activity against } \text { M. luteus } \\
\text { and only the extract from galangal } \\
\text { rhizome showed antifungal } \\
\text { activity toward } \text { A. niger. }\end{array}$ & [135] \\
\hline
\end{tabular}




\section{Black Pepper}

Black pepper (Piper nigrum) (Table 13) is largely used as a flavoring agent in foods. The antifungal effects of $\mathrm{EO}$ and acetone extract of black pepper on various pathogenic fungi were tested by the inverted petriplate technique and food poisoning technique [136]. The results showed that the EO was $100 \%$ controlled the mycelial growth of F. graminearum, while the acetone extract $100 \%$ inhibited mycelial growth of Penicillium viridcatum and A. ochraceus. In another study, the bacterial effects of EOs and acetone extracts of four spices on S. aureus, B. cereus, B. subtilis, E. coli, S. typhi, and P. aeruginosa were studied using the disk diffusion and poison food assay [137]. The results showed that black pepper extracts completely reduced colonies of S. aureus, B. cereus, and B. subtilis at 5 and $10 \mu \mathrm{L}$ levels using the poison food method. Zarai et al. [138] evaluated the antimicrobial effects of various solvent extracts, piperine, and piperic acid from pepper against E. coli, K. pneumonia, S. enterica, S. aureus, S. epidermidis, E. faecalis, and B. subtilis by the agar diffusion assay and micro-well dilution assay. The results showed that the ethanol extract was the most effective to the tested bacteria with the MICs ranging from $156.25 \mu \mathrm{g} / \mathrm{mL}$ (S. aureus and B. subtilus) to $1250 \mu \mathrm{g} / \mathrm{mL}$ (E. coli and K. pneumonia).

Table 13. Antibacterial and antifungal activities of black pepper

\begin{tabular}{|c|c|c|c|}
\hline Type of Samples & Bacteria and Fungi & Main Results & Reference \\
\hline $\begin{array}{l}\text { Black pepper EO and } \\
\text { acetone extract }\end{array}$ & $\begin{array}{l}\text { A. flavus, A. ochraceus, A.oryzae, } \\
\text { A. niger, F. moniliforme, F. graminearum, } \\
\text { Penicillium citrinum, Penicillium } \\
\text { viridcatum, P. madriti, Curvularia lunata }\end{array}$ & $\begin{array}{l}\text { The EO was effective against } \\
\text { F. graminearum, while the acetone } \\
\text { extract was effective against } \\
P . \text { viridcatum and } A \text {. ochraceus. }\end{array}$ & [136] \\
\hline $\begin{array}{l}4 \text { spice EOs and acetone } \\
\text { extracts }\end{array}$ & $\begin{array}{l}\text { S. aureus, B. cereus, B. subtilis, E. coli, } \\
\text { S. typhimurium, P. aeruginosa }\end{array}$ & $\begin{array}{l}\text { Black pepper extracts showed } \\
\text { complete reduction of colonies } \\
\text { against tested bacterial strains at } 5 \\
\text { and } 10 \mu \mathrm{L} \text { levels. }\end{array}$ & [137] \\
\hline $\begin{array}{l}\text { Various solvent extracts, } \\
\text { piperine and piperic acid } \\
\text { from pepper }\end{array}$ & $\begin{array}{l}\text { E. coli, K. pneumonia, S. enterica, } \\
\text { S. aureus, S. epidermidis, E. faecalis, } \\
\text { B. subtilis }\end{array}$ & $\begin{array}{l}\text { The ethanol extract was the most } \\
\text { effective with the MICs ranging } \\
\text { from } 156.25 \text { to } 1250 \mu \mathrm{g} / \mathrm{mL} \text {. }\end{array}$ & [138] \\
\hline
\end{tabular}

Black pepper EO could cause physical and morphological alterations in the cell walls and membranes of E. coli, and then result in the leakage of electrolytes, ATP, proteins, and DNA materials [139]. Chemical components of black pepper and its mechanisms of antimicrobial action need further exploration.

\section{Other Spices}

The antimicrobial activities of the spices mentioned above against several common microorganisms are summarized in Table 14. Other spices-such as Allium roseum L., Cinnamomum verum, Laurus nobilis, Myristica fragrans, and Pimpinella anisum - were also proved to possess significant antifungal and antibacterial activities (Table 15). 
Table 14. Antimicrobial activities of spices against several common microorganisms.

\begin{tabular}{|c|c|c|c|}
\hline Bacteria and Fungi & Spices & Type of Samples & Reference \\
\hline \multirow{51}{*}{ E. coli } & \multirow{7}{*}{ Clove } & Aqueous extract & [18] \\
\hline & & Acetone extract & {$[27]$} \\
\hline & & EO & {$[23,30,31]$} \\
\hline & & Ethyl acetate extract & [27] \\
\hline & & Ethyl heptanoate extract & [30] \\
\hline & & Methanol extract & [27] \\
\hline & & Powder & {$[19,29]$} \\
\hline & \multirow{3}{*}{ Oregano } & Aqueous extract & [40] \\
\hline & & EO & {$[36,44,47,49]$} \\
\hline & & EO-rich fractions & [35] \\
\hline & \multirow{5}{*}{ Thyme } & Decoction & [62] \\
\hline & & EO & {$[51,52,60]$} \\
\hline & & Hydroalcoholic extract & [62] \\
\hline & & Hydrosol & [56] \\
\hline & & Infusion & [62] \\
\hline & \multirow{8}{*}{ Cinnamon } & Acetone extract & [27] \\
\hline & & Aqueous extract & {$[75]$} \\
\hline & & Diethyl ether extract & [76] \\
\hline & & $\mathrm{EO}$ & {$[78,79]$} \\
\hline & & Ethyl acetate extract & {$[27]$} \\
\hline & & Hydrosol & [56] \\
\hline & & Methanol extract & [27] \\
\hline & & Powder & [71] \\
\hline & Cumin & $\mathrm{EO}$ & {$[80,81,83,85-89]$} \\
\hline & \multirow{4}{*}{ Rosemary } & Aqueous extract & [93] \\
\hline & & EO & {$[88,92]$} \\
\hline & & Ethanol extract & [93-95] \\
\hline & & Hexane extract & [93] \\
\hline & \multirow{5}{*}{ Garlic } & Acetone extract & [105] \\
\hline & & Aqueous extract & [103] \\
\hline & & Ethanol extract & {$[104,105]$} \\
\hline & & Hexane extract & [105] \\
\hline & & Powder & [99] \\
\hline & Ginger & Aqueous extract & [103] \\
\hline & \multirow{4}{*}{ Basil } & Acetone extract & [114] \\
\hline & & Chloroform extract & [114] \\
\hline & & $\mathrm{EO}$ & {$[113,116]$} \\
\hline & & Methanol extract & [114] \\
\hline & \multirow{4}{*}{ Fennel } & Crude extract & [121] \\
\hline & & $\mathrm{EO}$ & {$[121,122]$} \\
\hline & & Ethanol extract & [123] \\
\hline & & Methanol extract & [123] \\
\hline & \multirow{2}{*}{ Coriander } & Aqueous-ethanol extract & [131] \\
\hline & & Ethanol extract & [131] \\
\hline & \multirow{4}{*}{ Galangal } & Acetone extract & [133] \\
\hline & & Diethyl ether extract & [133] \\
\hline & & Hexane extract & [134] \\
\hline & & Methanol extract & [133] \\
\hline & \multirow{3}{*}{ Black pepper } & Acetone extract & [137] \\
\hline & & $\mathrm{EO}$ & [137] \\
\hline & & Ethanol extract & [138] \\
\hline
\end{tabular}


Table 14. Cont.

\begin{tabular}{|c|c|c|c|}
\hline Bacteria and Fungi & Spices & Type of Samples & Reference \\
\hline \multirow{43}{*}{ S. aureus } & \multirow{7}{*}{ Clove } & Acetone extract & [27] \\
\hline & & Aqueous extract & [18] \\
\hline & & $\mathrm{EO}$ & [30-32] \\
\hline & & Ethanol extract & [24] \\
\hline & & Ethyl heptanoate extract & {$[30,31]$} \\
\hline & & Methanol extract & {$[27]$} \\
\hline & & Powder & {$[19,29]$} \\
\hline & \multirow{2}{*}{ Oregano } & $\mathrm{EO}$ & {$[36,41,47]$} \\
\hline & & EO-rich fractions & [35] \\
\hline & \multirow{4}{*}{ Thyme } & Decoction & {$[62]$} \\
\hline & & $\mathrm{EO}$ & {$[51,52]$} \\
\hline & & Hydroalcoholic extract & {$[62]$} \\
\hline & & Infusion & {$[62]$} \\
\hline & \multirow{7}{*}{ Cinnamon } & Acetone extract & [27] \\
\hline & & Aqueous extract & [75] \\
\hline & & Diethyl ether extract & [76] \\
\hline & & $\mathrm{EO}$ & {$[72,78,79]$} \\
\hline & & Ethyl acetate extract & [27] \\
\hline & & Hydrosol & [56] \\
\hline & & Methanol extract & [27] \\
\hline & Cumin & $\mathrm{EO}$ & {$[80,81,83,86,88,89]$} \\
\hline & \multirow{3}{*}{ Rosemary } & EO & {$[88,92]$} \\
\hline & & Ethanol extract & {$[94,97]$} \\
\hline & & Hexane extract & {$[93]$} \\
\hline & \multirow{5}{*}{ Garlic } & Aqueous extract & [98] \\
\hline & & Acetone extract & [105] \\
\hline & & Ethanol extract & {$[104,105]$} \\
\hline & & Hexane extract & [105] \\
\hline & & Powder & [99] \\
\hline & \multirow{4}{*}{ Basil } & Acetone extract & [114] \\
\hline & & Chloroform extract & [114] \\
\hline & & $\mathrm{EO}$ & {$[113,116]$} \\
\hline & & Methanol extract & [114] \\
\hline & \multirow{2}{*}{ Coriander } & Aqueous-ethanol extract & [131] \\
\hline & & Ethanol extract & [131] \\
\hline & \multirow{5}{*}{ Galangal } & Acetone extract & [133] \\
\hline & & Diethyl ether extract & [133] \\
\hline & & Ethanol extract & [93] \\
\hline & & Hexane extract & {$[93,134]$} \\
\hline & & Methanol & [133] \\
\hline & \multirow{3}{*}{ Black pepper } & Acetone extract & [137] \\
\hline & & $\mathrm{EO}$ & [137] \\
\hline & & Ethanol extract & [138] \\
\hline
\end{tabular}


Table 14. Cont.

\begin{tabular}{|c|c|c|c|}
\hline Bacteria and Fungi & Spices & Type of Samples & Reference \\
\hline \multirow{20}{*}{ L. monocytogenes } & \multirow{3}{*}{ Clove } & Ethanol extract & {$[24,25]$} \\
\hline & & Ethyl heptanoate extract & {$[30,31]$} \\
\hline & & $\mathrm{EO}$ & {$[30,31]$} \\
\hline & Oregano & $\mathrm{EO}$ & [49] \\
\hline & Thyme & $\mathrm{EO}$ & {$[60]$} \\
\hline & Cinnamon & $\mathrm{EO}$ & {$[78,79]$} \\
\hline & Cumin & $\mathrm{EO}$ & [89] \\
\hline & \multirow{3}{*}{ Rosemary } & Aqueous extract & {$[93]$} \\
\hline & & Ethanol extract & {$[93-95,97]$} \\
\hline & & Hexane extract & [93] \\
\hline & Garlic & Aqueous extract & [103] \\
\hline & Ginger & $\mathrm{EO}$ & [111] \\
\hline & \multirow{4}{*}{ Basil } & Acetone extract & [114] \\
\hline & & Chloroform & [114] \\
\hline & & $\mathrm{EO}$ & [116] \\
\hline & & Methanol extract & [114] \\
\hline & \multirow{2}{*}{ Coriander } & Aqueous-ethanol extract & [131] \\
\hline & & Ethanol extract & [131] \\
\hline & \multirow{2}{*}{ Galangal } & Ethanol extract & [93] \\
\hline & & Hexane extract & {$[93,134]$} \\
\hline \multirow{20}{*}{ S. typhimurium } & \multirow{3}{*}{ Clove } & $\mathrm{EO}$ & {$[23,30,31]$} \\
\hline & & Ethyl heptanoate extract & [30] \\
\hline & & Powder & [29] \\
\hline & Oregano & Extract & {$[34]$} \\
\hline & \multirow{2}{*}{ Thyme } & $\mathrm{EO}$ & {$[52,60]$} \\
\hline & & Hydrosol & {$[56]$} \\
\hline & Cumin & $\mathrm{EO}$ & {$[86,89]$} \\
\hline & \multirow{4}{*}{ Rosemary } & Aqueous extract & [93] \\
\hline & & EO & [92] \\
\hline & & Ethanol extract & [93] \\
\hline & & Hexane extract & [93] \\
\hline & Garlic & Powder & [99] \\
\hline & Basil & $\mathrm{EO}$ & [116] \\
\hline & Fennel & $\mathrm{EO}$ & {$[121,122]$} \\
\hline & \multirow{4}{*}{ Galangal } & Acetone extract & [133] \\
\hline & & Diethyl ether extract & {$[133]$} \\
\hline & & Hexane extract & [134] \\
\hline & & Methanol extract & [133] \\
\hline & \multirow{2}{*}{ Black pepper } & Acetone extract & [137] \\
\hline & & EO & [137] \\
\hline \multirow{13}{*}{ P. aeruginosa } & \multirow{4}{*}{ Clove } & Acetone extract & [27] \\
\hline & & EO & {$[32]$} \\
\hline & & Ethyl acetate extract & [27] \\
\hline & & Methanol extract & {$[27]$} \\
\hline & Oregano & EO-rich fractions & [35] \\
\hline & \multirow{4}{*}{ Thyme } & Decoction & {$[62]$} \\
\hline & & EO & {$[51,53,57]$} \\
\hline & & Hydroalcoholic extract & [62] \\
\hline & & Infusion & {$[62]$} \\
\hline & \multirow{4}{*}{ Cinnamon } & Diethyl ether extract & {$[76]$} \\
\hline & & $\mathrm{EO}$ & [79] \\
\hline & & Hydrosol & [56] \\
\hline & & Methanol extract & {$[27]$} \\
\hline
\end{tabular}


Table 14. Cont.

\begin{tabular}{|c|c|c|c|}
\hline Bacteria and Fungi & Spices & Type of Samples & Reference \\
\hline \multirow{9}{*}{ P. aeruginosa } & Cumin & $\mathrm{EO}$ & {$[83,87]$} \\
\hline & \multirow{2}{*}{ Rosemary } & $\mathrm{EO}$ & [92] \\
\hline & & Ethanol extract & [94] \\
\hline & Ginger & EO & [108] \\
\hline & Basil & $\begin{array}{l}\text { Acetone extract } \\
\text { Chloroform } \\
\text { EO } \\
\text { Methanol extract }\end{array}$ & $\begin{array}{l}{[114]} \\
{[114]} \\
{[116]} \\
{[114]}\end{array}$ \\
\hline & Fennel & $\mathrm{EO}$ & [121] \\
\hline & Coriander & $\begin{array}{c}\text { Aqueous-ethanol extract } \\
\text { Ethanol extract }\end{array}$ & $\begin{array}{l}{[131]} \\
{[131]}\end{array}$ \\
\hline & Galangal & $\begin{array}{l}\text { Acetone extract } \\
\text { Diethyl ether extract } \\
\text { Methanol extract }\end{array}$ & $\begin{array}{l}{[133]} \\
{[133]} \\
{[133]}\end{array}$ \\
\hline & Black pepper & $\begin{array}{c}\text { Acetone extract } \\
\text { EO }\end{array}$ & $\begin{array}{l}{[137]} \\
{[137]}\end{array}$ \\
\hline \multirow{7}{*}{ B. subtilis } & Oregano & $\begin{array}{l}\text { Aqueous extract } \\
\text { EO-rich fractions }\end{array}$ & $\begin{array}{l}{[40]} \\
{[35]}\end{array}$ \\
\hline & Thyme & $\begin{array}{c}\text { EO } \\
\text { Hydrosol }\end{array}$ & $\begin{array}{l}{[51]} \\
{[55]}\end{array}$ \\
\hline & $\begin{array}{c}\text { Cinnamon } \\
\text { Rosemary } \\
\text { Garlic } \\
\text { Ginger } \\
\text { Basil }\end{array}$ & $\begin{array}{c}\text { EO } \\
\text { EO } \\
\text { Hydrosol } \\
\text { EO } \\
\text { EO }\end{array}$ & $\begin{array}{c}{[79]} \\
{[92]} \\
{[55]} \\
{[108]} \\
{[113]}\end{array}$ \\
\hline & Fennel & $\begin{array}{c}\text { EO } \\
\text { Ethanol extract } \\
\text { Methanol extract }\end{array}$ & $\begin{array}{l}{[121]} \\
{[123]} \\
{[123]}\end{array}$ \\
\hline & Coriander & $\begin{array}{l}\text { Aqueous-ethanol extract } \\
\text { Ethanol extract }\end{array}$ & $\begin{array}{l}{[131]} \\
{[131]}\end{array}$ \\
\hline & Galangal & $\begin{array}{l}\text { Acetone extract } \\
\text { Diethyl ether extract } \\
\text { Methanol extract }\end{array}$ & $\begin{array}{l}{[133]} \\
{[133]} \\
{[133]}\end{array}$ \\
\hline & Black pepper & $\begin{array}{l}\text { Acetone extract } \\
\text { EO } \\
\text { Ethanol extract }\end{array}$ & $\begin{array}{l}{[137]} \\
{[137]} \\
{[138]}\end{array}$ \\
\hline \multirow{3}{*}{ B. cereus } & Clove & $\begin{array}{c}\text { EO } \\
\text { Ethyl heptanoate extract }\end{array}$ & $\begin{array}{c}{[23,30,31]} \\
{[30]}\end{array}$ \\
\hline & $\begin{array}{l}\text { Oregano } \\
\text { Thyme } \\
\text { Cinnamon } \\
\text { Cumin } \\
\text { Rosemary } \\
\text { Garlic } \\
\text { Basil }\end{array}$ & $\begin{array}{c}\text { EO } \\
\text { EO } \\
\text { EO } \\
\text { EO } \\
\text { Ethanol extract } \\
\text { Powder } \\
\text { EO }\end{array}$ & $\begin{array}{c}{[36]} \\
{[60]} \\
{[78,79]} \\
{[80,86,89]} \\
{[94]} \\
{[99]} \\
{[116]}\end{array}$ \\
\hline & Black pepper & $\begin{array}{c}\text { Acetone extract } \\
\text { EO }\end{array}$ & $\begin{array}{l}{[137]} \\
{[137]}\end{array}$ \\
\hline
\end{tabular}


Table 14. Cont.

\begin{tabular}{|c|c|c|c|}
\hline Bacteria and Fungi & Spices & Type of Samples & Reference \\
\hline \multirow{10}{*}{ E. faecalis } & Cinnamon & Diethyl ether extract & {$[76]$} \\
\hline & Cumin & $\mathrm{EO}$ & {$[86,88]$} \\
\hline & Rosemary & $\mathrm{EO}$ & {$[88]$} \\
\hline & Basil & $\mathrm{EO}$ & [116] \\
\hline & \multirow{2}{*}{ Fennel } & Ethanol extract & [123] \\
\hline & & Methanol extract & [123] \\
\hline & \multirow{3}{*}{ Galangal } & Acetone extract & [133] \\
\hline & & Diethyl ether extract & [133] \\
\hline & & Methanol extract & [133] \\
\hline & Black pepper & Ethanol extract & [138] \\
\hline \multirow{9}{*}{ E. faecalis } & Cinnamon & Diethyl ether extract & [76] \\
\hline & Cumin & $\mathrm{EO}$ & {$[86,88]$} \\
\hline & Basil & $\mathrm{EO}$ & [116] \\
\hline & \multirow[b]{2}{*}{ Fennel } & Ethanol extract & [123] \\
\hline & & Methanol extract & [123] \\
\hline & \multirow{3}{*}{ Galangal } & Acetone extract & [133] \\
\hline & & Diethyl ether extract & [133] \\
\hline & & Methanol extract & [133] \\
\hline & Black pepper & Ethanol extract & [138] \\
\hline \multirow{13}{*}{ K. pneumoniae } & \multirow{3}{*}{ Clove } & Acetone extract & [27] \\
\hline & & Ethyl acetate & [27] \\
\hline & & Methanol extract & [27] \\
\hline & \multirow{5}{*}{ Cinnamon } & Acetone extract & [27] \\
\hline & & Diethyl ether extract & {$[76]$} \\
\hline & & $\mathrm{EO}$ & [79] \\
\hline & & Ethyl acetate & [27] \\
\hline & & Methanol extract & [27] \\
\hline & Garlic & Ethanol extract & [104] \\
\hline & \multirow{3}{*}{ Galangal } & Acetone extract & [133] \\
\hline & & Diethyl ether extract & [133] \\
\hline & & Methanol extract & [133] \\
\hline & Black pepper & Ethanol extract & [138] \\
\hline \multirow{8}{*}{ P. vulgaris } & \multirow{4}{*}{ Thyme } & Decoction & [62] \\
\hline & & EO & {$[52]$} \\
\hline & & Hydroalcoholic extract & [62] \\
\hline & & Infusion & [62] \\
\hline & Garlic & Ethanol extract & [104] \\
\hline & Fennel & Crude extract & [121] \\
\hline & \multirow{2}{*}{ Coriander } & Aqueous-ethanol extract & [131] \\
\hline & & Ethanol extract & [131] \\
\hline \multirow{4}{*}{ P. fluorescens } & Clove & Powder & [19] \\
\hline & Thyme & $\mathrm{EO}$ & {$[52,57,59]$} \\
\hline & Cinnamon & $\mathrm{EO}$ & [78] \\
\hline & Rosemary & Ethanol extract & [95] \\
\hline \multirow{4}{*}{ L. innocua } & Clove & $\mathrm{EO}$ & [23] \\
\hline & Thyme & $\mathrm{EO}$ & {$[52,52,59]$} \\
\hline & \multirow{2}{*}{ Fennel } & Ethanol extract & [123] \\
\hline & & Methanol extract & [123] \\
\hline
\end{tabular}


Table 14. Cont.

\begin{tabular}{|c|c|c|c|}
\hline Bacteria and Fungi & Spices & Type of Samples & Reference \\
\hline \multirow{9}{*}{ S. faecalis } & \multirow{3}{*}{ Clove } & Acetone extract & [27] \\
\hline & & Ethyl acetate & [27] \\
\hline & & Methanol extract & [27] \\
\hline & \multirow{3}{*}{ Cinnamon } & Acetone extract & [27] \\
\hline & & Ethyl acetate & [27] \\
\hline & & Methanol extract & [27] \\
\hline & \multirow{3}{*}{ Cumin } & Decoctions & [81] \\
\hline & & EO & [88] \\
\hline & & Infusions & [81] \\
\hline \multirow{3}{*}{ S. enteritidis } & Thyme & Hydrosol & [55] \\
\hline & Garlic & Hydrosol & [55] \\
\hline & Ginger & EO & [108] \\
\hline \multirow{3}{*}{ M. luteus } & Cinnamon & Diethyl ether extract & {$[76]$} \\
\hline & Cumin & $\mathrm{EO}$ & [88] \\
\hline & Galangal & Methanol extract & [135] \\
\hline \multirow{7}{*}{ B. megaterium } & \multirow{3}{*}{ Clove } & Acetone extract & [27] \\
\hline & & Ethyl acetate & [27] \\
\hline & & Methanol extract & [27] \\
\hline & \multirow{3}{*}{ Cinnamon } & Acetone extract & [27] \\
\hline & & Ethyl acetate & [27] \\
\hline & & Methanol extract & [27] \\
\hline & Cumin & $\mathrm{EO}$ & [88] \\
\hline \multirow{2}{*}{ A. hydrophila } & Cumin & EO & [88] \\
\hline & Garlic & Aqueous extract & [103] \\
\hline \multirow{5}{*}{ S. epidermidis } & \multirow{4}{*}{ Thyme } & Decoction & [62] \\
\hline & & $\mathrm{EO}$ & [51] \\
\hline & & Hydroalcoholic extract & {$[62]$} \\
\hline & & Infusion & [62] \\
\hline & Black pepper & Ethanol extract & [138] \\
\hline \multirow{10}{*}{ C. albicans } & Clove & $\mathrm{EO}$ & [22] \\
\hline & Oregano & $\mathrm{EO}$ & {$[35,36]$} \\
\hline & Thyme & $\mathrm{EO}$ & {$[51,57]$} \\
\hline & Cinnamon & $\begin{array}{c}\text { Hydrosol } \\
\text { Diethyl ether extract }\end{array}$ & $\begin{array}{c}{[56,76]} \\
{[76]}\end{array}$ \\
\hline & Cumin & $\mathrm{EO}$ & [83] \\
\hline & Rosemary & $\mathrm{EO}$ & {$[92]$} \\
\hline & Garlic & Ethanol extract & [104] \\
\hline & & Aqueous-ethanol extract & [131] \\
\hline & Coriander & $\mathrm{EO}$ & [127] \\
\hline & & Ethanol extract & [131] \\
\hline
\end{tabular}


Table 14. Cont.

\begin{tabular}{|c|c|c|c|}
\hline Bacteria and Fungi & Spices & Type of Samples & Reference \\
\hline \multirow{11}{*}{ A. niger } & Oregano & EO-rich fraction & [35] \\
\hline & Cinnamon & Aqueous extract & {$[74]$} \\
\hline & Cumin & $\mathrm{EO}$ & [83] \\
\hline & \multirow{3}{*}{ Ginger } & Aqueous extract & {$[74,109]$} \\
\hline & & $\mathrm{EO}$ & [109] \\
\hline & & Oleoresin & [109] \\
\hline & Basil & $\mathrm{EO}$ & {$[113,116]$} \\
\hline & \multirow[b]{2}{*}{ Fennel } & Acetone extract & [118] \\
\hline & & $\mathrm{EO}$ & [118] \\
\hline & Coriander & $\mathrm{EO}$ & [130] \\
\hline & Galangal & Methanol extract & [135] \\
\hline \multirow{3}{*}{ A. flavus } & Basil & $\mathrm{EO}$ & [117] \\
\hline & \multirow{2}{*}{ Fennel } & Acetone extract & [118] \\
\hline & & EO & [118] \\
\hline \multirow{5}{*}{ F. oxysporum } & oregano & Decoction & [39] \\
\hline & ginger & EO & [109] \\
\hline & basil & Extract & [115] \\
\hline & \multirow{2}{*}{ coriander } & $\mathrm{EO}$ & [130] \\
\hline & & Oleoresin & [130] \\
\hline \multirow{6}{*}{ F. graminearum } & \multirow{2}{*}{ Fennel } & Acetone extract & [118] \\
\hline & & $\mathrm{EO}$ & [118] \\
\hline & \multirow{2}{*}{ Coriander } & $\mathrm{EO}$ & [130] \\
\hline & & Oleoresin & [130] \\
\hline & \multirow{2}{*}{ Black pepper } & Acetone extract & [136] \\
\hline & & $\mathrm{EO}$ & [136] \\
\hline \multirow{2}{*}{ S. cerevisiae } & Thyme & $\mathrm{EO}$ & [52] \\
\hline & Cumin & $\mathrm{EO}$ & [86] \\
\hline
\end{tabular}


Table 15. Antibacterial and antifungal activities of other spices.

\begin{tabular}{|c|c|c|c|c|}
\hline Spices & Type of Samples & Bacteria and Fungi & Main Results & Reference \\
\hline Achillea species & Ethanol extract & $\begin{array}{l}\text { K. pneumoniae, E. cloacae, S. typhimurium, } \\
\text { S. epidermis, E. coli, E. aerogenes, S. aureus, Klebsiella } \\
\text { oxytoca, S. pyogenes, P. aeruginosa, C. albicans }\end{array}$ & $\begin{array}{l}\text { Achillea species showed a broad spectrum of } \\
\text { strong antibacterial activities against all tested } \\
\text { microorganisms. }\end{array}$ & [140] \\
\hline Achillea millefolium & Ethanol extract & $\begin{array}{l}\text { S. aureus, S. enteritidis, E. coli, S. pneumoniae, } \\
\text { K. pneumoniae, P. aeruginosa, E. aerogenes, } \\
\text { P. mirabilis, A. niger, C. albicans }\end{array}$ & $\begin{array}{l}\text { The antibacterial activities of A. millefolium were } \\
\text { greater or similar to other penicillin derivatives } \\
\text { but lesser than Ampicillin. }\end{array}$ & [141] \\
\hline Aframomum corrorima & $\begin{array}{l}\text { Seeds, pods, leaves and } \\
\text { rhizomes extract }\end{array}$ & A. flavus and Penicillum expansum & $\begin{array}{l}\text { A. corrorima crude seed extract was the most active } \\
\text { against } A \text {. flavus and } P \text {. expansum at concentration } \\
\text { of } 0.4 \mathrm{mg} / \mathrm{mL} \text {. }\end{array}$ & [142] \\
\hline $\begin{array}{l}\text { Allium hirtifolium } \\
\text { Boiss. }\end{array}$ & Hydromethanol extract & $\begin{array}{l}\text { MRSA, S. epidermidis, S. pneumoniae, E. coli, } \\
\text { S. typhimurium, P. mirabilis, K. pneumoniae }\end{array}$ & $\begin{array}{l}\text { A. hirtifolium extract was effective against } 10 \\
\text { species of pathogenic bacteria with MICs ranging } \\
\text { from } 1.88 \text { to } 7.50 \mathrm{mg} / \mathrm{mL} \text {. }\end{array}$ & [143] \\
\hline Allium roseum $\mathrm{L}$. & $\begin{array}{l}\text { Extracts of bulbs, leaves, } \\
\text { flowers and seeds by } 3 \\
\text { extraction methods }\end{array}$ & $\begin{array}{l}\text { S. aureu, S. epidermidis, M. luteus, B. cereus, } \\
\text { B. subtilis, E. faecalis, S. typhimurium, E. coli, } \\
\text { P. aeruginosa, C. albicans }\end{array}$ & $\begin{array}{l}\text { A. roseum extract showed very significant } \\
\text { antimicrobial activities to strains such as C. albicans } \\
\text { (MICs: } 1.00-3.44 \mu \mathrm{g} / \mu \mathrm{L} \text { ) and E. coli (MICs: } \\
\text { 2.00-3.44 } \mu \mathrm{g} / \mu \mathrm{L} \text { ). }\end{array}$ & [144] \\
\hline Allium ursinum L. & Pressurized-liquid extract & S. aureus and A. niger & $\begin{array}{l}\text { A. ursinum extract showed antimicrobial activities } \\
\text { against } S \text {. aureus with DIZs of } 12 \text { and } 10 \mathrm{~mm} \text { (two } \\
\text { parallel determinations) and A. niger of } 6 \mathrm{~mm} \text {. }\end{array}$ & [145] \\
\hline Amomum kravanh & $\mathrm{EO}$ & Different foodborne pathogens & $\begin{array}{l}\text { A. kravanh } \mathrm{EO} \text { exhibited the best antibacterial } \\
\text { activities against B. subtilis and E. coli. }\end{array}$ & [146] \\
\hline Anethum graveolens L. & EO and acetone extract & $\begin{array}{l}\text { P. citrinum, A. niger, S. aureus, B. cereus, } \\
\text { P. aeruginosa }\end{array}$ & $\begin{array}{l}\text { EO and extract showed different but both effective } \\
\text { activities against tested microorganisms. }\end{array}$ & [147] \\
\hline Anethum graveolens L. & diethyl-ether extract & $\begin{array}{l}\text { P. aeruginosa, E. coli, K. pneumoniae, M. luteus, } \\
\text { E. faecalis, B. megaterium, S. aureus }\end{array}$ & $\begin{array}{l}\text { A. graveolens extract affected all of the bacteria } \\
\text { tested. }\end{array}$ & [148] \\
\hline Anethum graveolens L. & $\mathrm{EO}$ & A. flavus & $\begin{array}{l}\text { A. graveolens } \mathrm{EO} \text { is the most effective against } \\
\text { aflatoxin production. }\end{array}$ & [117] \\
\hline Brassica jancea & $\mathrm{EO}$ & Vibrio parahaemolyticus and Vibrio vulnificus & $\begin{array}{l}\text { B. jancea EO could inhibit } V \text {. parahaemolyticus and } \\
\text { Vibrio vulnificus inoculated sliced raw flatfish at } 5 \\
{ }^{\circ} \mathrm{C} \text { of storage. }\end{array}$ & [110] \\
\hline Brassica jancea & Water extract & E. coli, S. aureus, B. cereus & $\begin{array}{l}\text { B. jancea extract showed good inhibitory action at } \\
1 \% \text { concentration. }\end{array}$ & [149] \\
\hline
\end{tabular}


Table 15. Cont.

\begin{tabular}{|c|c|c|c|c|}
\hline Spices & Type of Samples & Bacteria and Fungi & Main Results & Reference \\
\hline Bunium persicum & Volatile compounds & F. oxysporum & $\begin{array}{l}\text { B. persicum showed the strongest effect compared } \\
\text { with other } 51 \text { spices and herbs. }\end{array}$ & [150] \\
\hline Caesulia axillaris Roxb. & $\mathrm{EO}$ & A. flavus & $\begin{array}{l}\text { C. axillaris } \mathrm{EO} \text { showed complete inhibition against } \\
\text { A. flavus at } 1.0 \mu \mathrm{g} / \mathrm{mL} \text {. }\end{array}$ & [151] \\
\hline Capsicum froutescens & Ethanol extract & S. aureus & C. froutescens extract showed the highest activity. & [152] \\
\hline Capsicum frutescens $\mathrm{L}$. & $\begin{array}{l}n \text {-hexane, chloroform, } \\
\text { ethyl acetate, acetone, and } \\
\text { methanol extracts of dried } \\
\text { seeds }\end{array}$ & $\begin{array}{l}\text { B. cereus, S. aureus, MRSA, E. coli, S. typhimurium, } \\
\text { P. aeruginosa, K. pneumoniae, P. vulgaris, C. albicans, } \\
\text { C. krusei }\end{array}$ & $\begin{array}{l}\text { Microwave assisted solvent extracts showed } \\
\text { significant activities and } n \text {-hexane extract was } \\
\text { effective against } P \text {. aeruginosa and } C \text {. albicans, while } \\
\text { ethyl acetate extract was effective against } C \text {. krusei. }\end{array}$ & [153] \\
\hline Carum capticum & $\mathrm{EO}$ & $\begin{array}{l}\text { Corynebacterium diphtheriae, S. aureus, } \\
\text { Staphylococcus haemolyticus, B. subtilis, P. aeruginosa, } \\
\text { E. coli, Klebsiella species, P. vulgaris }\end{array}$ & $\begin{array}{l}\text { C. capticum was very effective against all tested } \\
\text { bacteria. }\end{array}$ & [154] \\
\hline Carum copticum & $\mathrm{EO}$ & $\begin{array}{l}\text { S. aureus, B. cereus, E. coli, S. enteritidis, } \\
\text { L. monocytogenes }\end{array}$ & $\begin{array}{l}\text { C. copticum EO was the most effective against } \\
\text { tested bacteria with MICs of } 0.03-0.5 \mathrm{mg} / \mathrm{mL} \\
\text { compared with two other spices. }\end{array}$ & [155] \\
\hline $\begin{array}{l}\text { Cinnamomum } \\
\text { burmannii }\end{array}$ & Methanol crude extract & $\begin{array}{l}\text { B. cereus, L. monocytogenes, S. aureus, E. coli, } \\
\text { Salmonella anatum }\end{array}$ & $\begin{array}{l}\text { MIC and MBC for B. cereus were } 625 \text { and } 2500 \\
\mu \mathrm{g} / \mathrm{mL} \text { respectively, for four other bacteria were } \\
\text { more than } 2500 \mu \mathrm{g} / \mathrm{mL} \text {. }\end{array}$ & [156] \\
\hline Cinnamomum cassia & Ultra-fine powder & $\begin{array}{l}\text { E. coli, S. aureus, P. fluorescens, L. rhamnosus, } \\
\text { B. thermosphacta }\end{array}$ & $\begin{array}{l}\text { C. cassia powder significantly reduced the } \\
\text { microorganisms tested at the concentration } \leq 2.5 \% \\
w / v \text { and the inhibitory effects were positive } \\
\text { correlated with concentrations. }\end{array}$ & [19] \\
\hline Cinnamomum tamala & Leaves EO & $\begin{array}{l}\text { C. albicans, A. niger, A. fumigatus, R. stolonifer, } \\
\text { Penicillium spp. }\end{array}$ & $\begin{array}{l}\text { The MFCs of EO against all the tested fungi were } \\
230 \mu \mathrm{g} / \mathrm{mL} \text {. }\end{array}$ & [157] \\
\hline Cinnamomum verum & $\begin{array}{l}\text { Bark and leaf extracts and } \\
\text { EO }\end{array}$ & Bacteria isolated from urine samples, and A. niger & $\begin{array}{l}\text { C. verum oil possessed stronger antimicrobial } \\
\text { activities than extracts. A. niger showed no growth } \\
\text { in the presence of oil. }\end{array}$ & [158] \\
\hline Cinnamomum verum & $\mathrm{EO}$ & $\begin{array}{l}\text { E. coli, S. typhimurium, S. aureus, B. subtilis, } \\
\text { A. flavus, C. albicans }\end{array}$ & $\begin{array}{l}\text { C. verum } \mathrm{EO} \text { treated group showed significant } \\
\text { decrease in viable bacterial counts. }\end{array}$ & [159] \\
\hline Cinnamomum verum & $\mathrm{EO}$ & $\begin{array}{l}\text { S. typhimurium, S. paratyphi, E. coli, S. aureus, } \\
\text { P. fluorescens, B. licheniformis }\end{array}$ & $\begin{array}{l}\text { C. verum bark EO showed the best antibacterial } \\
\text { activities with mean MICs ranging from } 2.9 \text { to } 4.8 \\
\mathrm{mg} / \mathrm{mL} \text {. }\end{array}$ & [160] \\
\hline
\end{tabular}


Table 15. Cont.

\begin{tabular}{|c|c|c|c|c|}
\hline Spices & Type of Samples & Bacteria and Fungi & Main Results & Reference \\
\hline Citrus aurantium $\mathrm{L}$. & Ethanol extract & E. coli, $P$. aeruginosa, S. aureus, B. cereus & $\begin{array}{l}\text { C. aurantium showed strong antimicrobial } \\
\text { activities against tested bacteria. }\end{array}$ & [161] \\
\hline Clinopodium ascendens & $\mathrm{EO}$ & $\begin{array}{l}\text { S. aureus, S. faecium, S. mutans, Agrobacterium } \\
\text { tumefasciens, E. coli, B. cinerea, C. albicans }\end{array}$ & $\begin{array}{l}\text { C. ascendens exhibited remarkable activity against } \\
\text { E. coli and was active against } A \text {. tumefasciens, } \\
\text { S. aureus, and } B \text {. cinerea. }\end{array}$ & [162] \\
\hline Corydothymus capitatus & $\mathrm{EO}$ & P. putida & $\begin{array}{l}\text { C. capitatus EO was the most active with a MIC of } \\
0.025 \% w / v \text { and a MTC of } 0.006 \% w / v \text {. }\end{array}$ & [163] \\
\hline $\begin{array}{l}\text { Cotoneaster } \\
\text { nummularioides }\end{array}$ & Leaves EO & B. cereus, S. aureus, Salmonella entrica, E. coli & $\begin{array}{l}\text { The extract of C. nummularioides showed strong } \\
\text { effects on two Gram-positive microorganisms } \\
\text { tested with higher sensitivity for B. cereus (MIC: } \\
3.125 \mathrm{mg} / \mathrm{mL} \text { ). }\end{array}$ & [164] \\
\hline Croton hirtus & $\mathrm{EO}$ & E. coli, S. aureus & $\begin{array}{l}\text { C. hirtus EO was effective against S. aureus with } \\
\text { MIC of } 512 \mu \mathrm{g} / \mathrm{mL} \text {. }\end{array}$ & [165] \\
\hline Cuminum nigrum L. & Polyphenolic compounds & $\begin{array}{l}\text { B. subtilis, B. cereus, Enterobacter spp., E. coli, } \\
\text { L. monocytogenes, S. aureus, Y. enterocolitica }\end{array}$ & $\begin{array}{l}\text { C. nigrum extract possessed significantly inhibitory } \\
\text { effects on B. subtilis, B. cereus, and S. aureus. }\end{array}$ & [166] \\
\hline Curcuma longa & Curcumin & S. aureus & $\begin{array}{l}\text { Antibacterial activity of curcumin against } S . \text { aureus } \\
\text { was enhanced with the increase of the } \\
\text { concentration. }\end{array}$ & [167] \\
\hline Cunila galioides & EO from aerial parts & $\begin{array}{l}15 \text { bacterial species including Bacillus sp., } \\
\text { L. monocytogenes, S. aureus, A. hydrophila, E. faecalis } \\
\text { etc. }\end{array}$ & $\begin{array}{l}\text { The oil of } C \text {. galioides citral efficiently controlled } \\
\text { some microorganisms, showing both contact and } \\
\text { gaseous activity. }\end{array}$ & [168] \\
\hline Dichrostachys glomerata & Methanol extract & $\begin{array}{l}\text { Providencia stuartii, } P \text {. aeruginosa, K.pneumoniae, } \\
\text { E. coli, E. aerogenes, E. cloacae }\end{array}$ & $\begin{array}{l}\text { D. glomerata extract inhibited the growth of all the } \\
29 \text { tested bacteria with MICs } \leq 1024 \mu \mathrm{g} / \mathrm{mL} \text {. }\end{array}$ & [169] \\
\hline Echinops giganteus & Methanol extract & $\begin{array}{l}\text { Mycobacterium tuberculosis } \mathrm{H}(37) \mathrm{Rv}, \text { Mycobacterium } \\
\text { tuberculosis } \mathrm{H} 37 \mathrm{Ra}\end{array}$ & $\begin{array}{l}\text { The extract of E. giganteus was the most effective } \\
\text { with MICs of } 32 \mu \mathrm{g} / \mathrm{mL} \text { and } 16 \mu \mathrm{g} / \mathrm{mL} \\
\text { respectively against } \mathrm{H} 37 \mathrm{Ra} \text { and } \mathrm{H}(37) \mathrm{Rv}, \\
\text { compared with other } 19 \text { spices. }\end{array}$ & [170] \\
\hline Elettaria cardamomum & Ethanol extract & $\begin{array}{l}4 \text { strains of Gram-positive bacteria and } 12 \text { strains } \\
\text { of Gram-negative bacteria }\end{array}$ & $\begin{array}{l}\text { E. cardamomum extract was effective against a } \\
\text { majority of the pathogens, MICs ranged from } 9.4 \\
\text { to } 18.75 \mathrm{mg} / \mathrm{mL} \text { except } E \text {. coli, B. cereus, and } \\
\text { E. cloacae which had a great sensitivity to the spice } \\
\text { extract (MICs }<2.34 \mathrm{mg} / \mathrm{mL} \text { ). }\end{array}$ & [171] \\
\hline
\end{tabular}


Table 15. Cont.

\begin{tabular}{|c|c|c|c|c|}
\hline Spices & Type of Samples & Bacteria and Fungi & Main Results & Reference \\
\hline Elettaria cardamomum & EO and various oleoresins & $\begin{array}{l}\text { S. aureus, B. cereus, E. coli, S. typhimurium, } \\
\text { A. terreus, Penicillium purpurogenum, } \\
\text { F. graminearum, Penicillium madriti }\end{array}$ & $\begin{array}{l}\text { The EO showed strong effects against bacteria } \\
\text { tested at } 3000 \mathrm{ppm} \text {, and the methanol and ethanol } \\
\text { oleoresins gave the best results against } \text { A. terreus at } \\
3000 \mathrm{ppm} \text {. }\end{array}$ & [172] \\
\hline Eucalyptus globulus & Hydrodistillated extract & S. aureus, B. subtilis, L. innocua, E. coli, P. aeruginosa & $\begin{array}{l}\text { E. globulus extract showed an inhibition effects } \\
\text { against all the tested bacteria with MIC of } 3 \text { and } \\
4 \mathrm{mg} / \mathrm{mL} \text {. }\end{array}$ & [173] \\
\hline Eucalyptus largiflorens & $\mathrm{EO}$ & $\begin{array}{l}\text { A. flavus, A. parasiticus, A. niger, Penicillium } \\
\text { chryzogenum, P. citrinum }\end{array}$ & $\begin{array}{l}\text { The leaf oil of E. largiflorens showed higher } \\
\text { antifungal activities than four other Eucalyptus } \\
\text { spices. }\end{array}$ & [174] \\
\hline Eucalyptus radiata & $\mathrm{EO}$ & $\begin{array}{l}\text { P. aeruginosa, E. coli , K. pneumoniae, S. typhimurium, } \\
\text { Acinetobacter baumannii, P. aeruginosa, } \\
\text { K. pneumoniae }\end{array}$ & $\begin{array}{l}\text { E. radiate showed better antibacterial activities } \\
\text { with MICs ranging from } 8 \text { to } 32 \mu \mathrm{L} / \mathrm{mL} \text {. }\end{array}$ & [175] \\
\hline $\begin{array}{l}\text { Eugenia caryophyllum } \\
\text { Bullock and Harrison }\end{array}$ & Aqueous extract & $\begin{array}{l}\text { S. aureus, S. typhimurium, E. coli, S. epidermidis, } \\
\text { L. plantarum, P. vulgaris }\end{array}$ & $\begin{array}{l}\text { The MICs and MBCs against all tested bacteria } \\
\text { ranged from } 1 \text { to } 4 \mathrm{~g} / \mathrm{L} \text { and } 2 \text { to } 8 \mathrm{~g} / \mathrm{L} \text {, } \\
\text { respectively. }\end{array}$ & [176] \\
\hline $\begin{array}{l}\text { Foeniculum vulgare ssp. } \\
\text { piperitum }\end{array}$ & $\mathrm{EO}$ & A. alternate, F. oxysporum, R. solani & $\begin{array}{l}100 \% \text { fungistatic effects were observed with } \\
40 \mathrm{ppm} \text { doses of } F . \text { vulgare oils. }\end{array}$ & [177] \\
\hline Glaucium elegans & Methanol extract & $\begin{array}{l}\text { E. coli, S. aureus, S. enteritidis, Bacillus anthracis, } \\
\text { Proteus }\end{array}$ & $\begin{array}{l}\text { G. elegans methanol extract had significant } \\
\text { antibacterial effects. }\end{array}$ & [178] \\
\hline Gloriosa superba Linn & $\begin{array}{l}\text { Methanol extract and } \\
\text { fractions in different } \\
\text { solvent systems }\end{array}$ & $\begin{array}{l}\text { C. albicans, Candida glaberata, Trichophyton } \\
\text { longifusus, M. canis, S. aureus, E. coli, B. subtilis, } \\
\text { K. pneumonae, S. flexneri, S. typhimurium }\end{array}$ & $\begin{array}{l}\text { The } n \text {-butanol fraction of G. superba showed } \\
\text { excellent antifungal activities and chloroform } \\
\text { fraction showed the highest antibacterial activity } \\
\text { against } S \text {. aureus. }\end{array}$ & [179] \\
\hline Helichrysum species & Methanol extracts & 13 bacteria and 2 yeasts & $\begin{array}{l}\text { All the extracts showed significant antimicrobial } \\
\text { activities against all tested microorganisms. }\end{array}$ & [180] \\
\hline $\begin{array}{l}4 \text { Helichrysum Mill. } \\
\text { plants }\end{array}$ & Methanol extracts & $\begin{array}{l}\text { A. hydrophila, Bacillus brevis, B. cereus, } \\
\text { K. pneumoniae, P. aeruginosa, S. aureus, E. coli, } M \text {. } \\
\text { morganii, M. smegmatis, P. mirabilis, Y. enterocolitica, } \\
\text { S. cerevisiae }\end{array}$ & $\begin{array}{l}\text { The methanol extracts had antibacterial activities } \\
\text { against the first six microorganisms listed. }\end{array}$ & [181] \\
\hline horseradish & Aqueous extract & S. aureus & $\begin{array}{l}\text { Horseradish water extract showed a higher } \\
\text { biological activity. }\end{array}$ & [182] \\
\hline
\end{tabular}


Table 15. Cont.

\begin{tabular}{|c|c|c|c|c|}
\hline Spices & Type of Samples & Bacteria and Fungi & Main Results & Reference \\
\hline Hyssopus officinalis L. & $\mathrm{EO}$ & $\begin{array}{l}\text { A. niger, A. ochraceus, A. versicolor, A. fumigatus, } \\
\text { Cladosporium cladosporioides, Cladosporium fulvum, } \\
\text { Penicillium funiculosum, Penicillium ochrochloron, } \\
\text { Trichoderma viride, C. albicans }\end{array}$ & $\begin{array}{l}\text { All tested EO and deodorized extracts showed } \\
\text { activities with the MICs ranging from } 4 \text { to } \\
16 \mathrm{mg} / \mathrm{mL} \text {. }\end{array}$ & [183] \\
\hline Laser trilobum $\mathrm{L}$. & Methanol extract & $\begin{array}{l}\text { S. aureus, P. vulgaris, P. mirabilis, B. cereus, } \\
\text { A. hydrophila, E. faecalis, K. pneumoniae, } \\
\text { S. typhimurium, E. aerogenes, E. coli }\end{array}$ & $\begin{array}{l}\text { The fruit extract had significant antimicrobial } \\
\text { effects on pathogen bacteria. }\end{array}$ & [184] \\
\hline Laurus nobilis & Ethanol extract & $\begin{array}{l}4 \text { Gram-positive bacteria and } 12 \text { Gram-negative } \\
\text { bacteria }\end{array}$ & $\begin{array}{l}\text { L. nobilis extract was effective in inhibiting a } \\
\text { majority of the pathogens, MICs ranged from } 4.7 \\
\text { to } 9.4 \mathrm{mg} / \mathrm{mL} \text {. }\end{array}$ & [185] \\
\hline Laurus nobilis L. & $\begin{array}{l}\text { EO and leaves ethanol, } \\
\text { water and hot water } \\
\text { extract }\end{array}$ & $\begin{array}{l}\text { B. thermosphacta, E. coli, L. innocua, L. monocytogenes, } \\
\text { P. putida, S. typhimurium, Shewanella putrefaciens }\end{array}$ & $\begin{array}{l}\text { L. nobilis EO exhibited strong antibacterial } \\
\text { activities against all tested bacteria. }\end{array}$ & [186] \\
\hline Laurus nobilis L. & $\begin{array}{l}\text { Aqueous, ethanol, ethyl } \\
\text { acetate and hexane } \\
\text { extracts }\end{array}$ & B. cereus, S. aureus, E. coli, K. pneumoniae, C. albicans & $\begin{array}{l}\text { Only aqueous extract of } L . \text { nobilis showed } \\
\text { anticandidal activities among the tested } 8 \text { plants. }\end{array}$ & [187] \\
\hline Lavandula officinalis & $\mathrm{EO}$ & L. innocua and P. fluorescens & $\begin{array}{l}\text { L. officinalis EO showed the highest activity against } \\
\text { L. innocua. }\end{array}$ & [188] \\
\hline $\begin{array}{l}\text { Lichen Xanthoria } \\
\text { parietina }\end{array}$ & Acetone extract & $\begin{array}{l}\text { S. aureus, E. faecalis, } P \text {. vulgaris, } P \text {. mirabilis, } \\
\text { S. typhimurium, E. cloacae, E. aerogenes, } P \text {. aeruginosa, } \\
\text { K. pneumoniae, R. solani, Botridis cinerea, C. albicans }\end{array}$ & $\begin{array}{l}\text { X. parietina acetone extract and parietin showed } \\
\text { similar activities on the nine bacteria tested, but } \\
\text { less active than parietin on the three fungi tested. }\end{array}$ & [189] \\
\hline Lippia grandis Schauer. & $\mathrm{EO}$ & $\begin{array}{l}\text { E. coli, P. aeruginosa, K. pneumoniae, S. aureus, } \\
\text { E. faecalis }\end{array}$ & $\begin{array}{l}\text { The EO was effective against } 75 \% \text { of the } \\
\text { microorganisms analyzed especially S. aureus, } \\
\text { E. faecalis, and E. coli. }\end{array}$ & [190] \\
\hline Lippia javanica & $\begin{array}{l}\text { Acetone and aqueous } \\
\text { extracts }\end{array}$ & $\begin{array}{l}\text { S. aureus, L. monocytogenes, S. typhimurium, E. coli, } \\
\text { A. fumigatus, A. niger, M. canis, Microsporum } \\
\text { gypseum, T. tonsurans, T. rubrum, T. mucoides, } \\
\text { Penicillium aurantiogriseum, Penicillium chrysogenum }\end{array}$ & $\begin{array}{l}\text { The aqueous and acetone extracts were active } \\
\text { against the bacterial strains, and the acetone } \\
\text { extract exhibited the antifungal activities higher } \\
\text { than even the reference drugs. }\end{array}$ & [191] \\
\hline $\begin{array}{l}\text { Lippia origanoides } \\
\text { H.B.K. }\end{array}$ & $\mathrm{EO}$ & $\begin{array}{l}\text { C. albicans, Candida parapsilosis, Candida } \\
\text { guilliermondii, Cryptococcus neoformans, } \\
\text { Trichophyton rubrum, Fonsecaea pedrosoi, S. aureus, } \\
\text { Lactobacillus casei, S. mutans }\end{array}$ & $\begin{array}{l}\text { L. origanoides EO showed highly significant } \\
\text { inhibition zones for all microorganisms tested. }\end{array}$ & [192] \\
\hline
\end{tabular}


Table 15. Cont.

\begin{tabular}{|c|c|c|c|c|}
\hline Spices & Type of Samples & Bacteria and Fungi & Main Results & Reference \\
\hline Litsea cubeba & $\mathrm{EO}$ & E. coli & $\begin{array}{l}\text { The MIC and MBC of L. cubeba against E. coli were } \\
\text { both } 0.125 \% v / v \text {. }\end{array}$ & [193] \\
\hline Melissa officinalis L. & $\begin{array}{l}\text { Ethanol, ethyl acetate and } \\
\text { aqueous extracts }\end{array}$ & $\begin{array}{l}\text { Agrobacterium tumefaciens, Bacillus mycoides, } \\
\text { B. subtilis, E. cloaceae, Erwinia carotovora, E. coli, } \\
\text { Proteus sp., P. fluorescens, S. aureus }\end{array}$ & $\begin{array}{l}\text { M. officinalis ethanol, ethyl acetate, and aqueous } \\
\text { extracts significantly enhanced the effectiveness of } \\
\text { tested preservatives (sodium benzoate, sodium } \\
\text { nitrite, and potassium sorbate). }\end{array}$ & [194] \\
\hline Mentha piperita $L$. & $\mathrm{EO}$ & $\begin{array}{l}\text { T. rubrum, T. tonsurans, T. schoenleinii, } \\
\text { T. mentagrophytes, M. canis, M. fulvum }\end{array}$ & $\begin{array}{l}\text { For effective concentration of } M \text {. piperita oil against } \\
\text { tested antropophilic dermatophytes, and MICs } \\
\text { ranged from } 0.1 \text { to } 1.5 \mu \mathrm{L} / \mathrm{mL} \text {. }\end{array}$ & [195] \\
\hline Mentha spicata $\mathrm{L}$. & $\begin{array}{l}\text { hexane, chloroform, ethyl } \\
\text { acetate, and aqueous } \\
\text { fractions of ethanol extract }\end{array}$ & $\begin{array}{l}\text { Salmonella paratyphi, Shigella boydii, S. aureus, E. coli, } \\
\text { Vibrio cholera, P. aeruginosa, E. faecalis, } \\
\text { S. typhimurium, P. vulgaris, K. pneumoniae }\end{array}$ & $\begin{array}{l}\text { M. spicata ethanol extract and its solvent fractions } \\
\text { effectively inhibited half of the microorganism } \\
\text { growth. }\end{array}$ & [196] \\
\hline Myristica argentea & Water extract & E. coli and S. aureus & $\begin{array}{l}\text { M. argentea were more effective against E. coli } \\
(\mathrm{MIC} \text { of } 9.80 \mathrm{mg} / \mathrm{mL} \text { ) and S. aureus (MIC of } 6.20 \\
\mathrm{mg} / \mathrm{mL} \text { ). }\end{array}$ & [197] \\
\hline Myristica fragrans & - & $\begin{array}{l}20 \text { different serogroups of } E . \text { coli, } 8 \text { serotypes of } \\
\text { Salmonella, L. monocytogenes, A. hydrophila }\end{array}$ & $\begin{array}{l}\text { M. fragrans showed good anti-listerial activity, } \\
\text { although activities against E. coli and Salmonella } \\
\text { were serotype dependent. }\end{array}$ & [103] \\
\hline Myristica fragrans & $\begin{array}{l}\text { Ethyl acetate and ethanol } \\
\text { extracts of flesh, mace and } \\
\text { seed }\end{array}$ & $\begin{array}{l}\text { S. mutans, Streptococcus mitis, Streptococcus } \\
\text { salivarius, Aggregatibacter actinomycetemcomitans, } \\
\text { P. gingivalis, Fusobacterium nucleatum }\end{array}$ & $\begin{array}{l}\text { Flesh ethyl acetate extract had the highest effects } \\
\text { against tested bacteria with mean MICs ranging } \\
\text { from } 0.625 \text { to } 1.25 \mathrm{mg} / \mathrm{mL} \text { among all tested } \\
\text { extracts. }\end{array}$ & [198] \\
\hline Myrtus communis & $\mathrm{EO}$ & $\begin{array}{l}\text { P. aeruginosa, S. typhimurium, E. coli, A. hydrophila, } \\
\text { L. monocytogenes, C. albicans }\end{array}$ & $\begin{array}{l}\text { M. communis EO exhibited antimicrobial activities } \\
\text { against all tested microorganisms, especially } \\
\text { Gram-negative bacteria. }\end{array}$ & [199] \\
\hline Myrtus communis L. & $\begin{array}{l}\text { Methanol, ethyl acetate, } \\
\text { acetone extracts }\end{array}$ & S. aureus, $P$. vulgaris, $P$. mirabilis & $\begin{array}{l}\text { The most effective extract was the methanol } \\
\text { extract from } M \text {. communis leaves against } S \text {. aureus. }\end{array}$ & [200] \\
\hline Myrica gale L. & $\mathrm{EO}$ & $\begin{array}{l}\text { A. flavus, Cladosporium cladosporioides, } \\
\text { Penicillium expansum }\end{array}$ & $\begin{array}{l}\text { A complete antifungal activity was observed at } \\
1000 \mathrm{ppm} \text { of } M \text {. gale EO against Cladosporium } \\
\text { cladosporioides. }\end{array}$ & [201] \\
\hline Nepeta alpina & $\mathrm{EO}$ & $\begin{array}{l}\text { Bacillus pumilus, E. coli, Kocuria varians, } \\
\text { L. monocytogenes, P. aeruginosa, S. typhimurium, } \\
\text { A. niger, A. flavus, C. glabrata }\end{array}$ & $\begin{array}{l}\text { The EO was active against L. monocytogenes with } \\
\text { MIC of } 32 \mu \mathrm{g} / \mathrm{mL} \text {. }\end{array}$ & [202] \\
\hline
\end{tabular}


Table 15. Cont.

\begin{tabular}{|c|c|c|c|c|}
\hline Spices & Type of Samples & Bacteria and Fungi & Main Results & Reference \\
\hline Nigella saliva L. & Aqueous extracts & Uromyces appendiculatus & $\begin{array}{l}N \text {. saliva extract was effective against } U \text {. } \\
\text { appendiculatus and controlled rust similar to } \\
\text { mancozeb fungicide at } 2 \text { and } 3 \% \text { concentrations. }\end{array}$ & [203] \\
\hline Nigella sativa $\mathrm{L}$. & n-hexan extract & 24 pathogenic, spoilage and lactic acid bacteria & $\begin{array}{l}\text { N. sativa oil showed antibacterial activities against } \\
\text { all the bacteria at all concentrations }(0.5 \%, 1.0 \% \\
\text { and } 2.0 \%) \text { tested. }\end{array}$ & [204] \\
\hline Ocimum canum & $\mathrm{EO}$ & $\begin{array}{l}\text { B. subtilis, E. coli, K. pneumoniae, M. luteus, } \\
\text { P. aeruginosa, Raoultella planticola, S. typhimurium, } \\
\text { S. mutans }\end{array}$ & $\begin{array}{l}\text { MICs of } O \text {. canum ranged from } 0.43 \text { to } 2.08 \mu \mathrm{L} / \mathrm{mL} \\
\text { against } 7 \text { out of } 10 \text { bacteria tested. }\end{array}$ & [205] \\
\hline Ocimum gratissimum $\mathrm{L}$. & $\mathrm{EO}$ & $\begin{array}{l}\text { A. flavus, A. niger, Aspergillus fumigatus, Aspergillus } \\
\text { terreus, Aspergillus sydowi, Aspergillus alternate, } \\
\text { Penicillium italicum, Fusarium nivale, C. lunata, } \\
\text { Cladosporium spp. }\end{array}$ & $\begin{array}{l}\text { The EO exhibited antifungal activities against } \\
\text { fungal isolates from some spices and showed } \\
\text { better efficacy as fungi toxicant than prevalent } \\
\text { fungicide Wettasul- } 80 \text {. }\end{array}$ & [206] \\
\hline Ocimum sanctum & $\mathrm{EO}$ & A. flavus & MIC: $0.3 \mu \mathrm{L} / \mathrm{mL}$. & [207] \\
\hline Ocimum sanctum $\mathrm{L}$. & $\mathrm{EO}$ & $\begin{array}{l}\text { A. flavus, Aspergillus fumigatus, Aspergillus clavatus, } \\
\text { Aspergillus orizae S. aureus, E. faecalis, E. coli, } \\
\text { enterohemorrhagic E. coli, P. aeruginosa, S. flexneri }\end{array}$ & $\begin{array}{l}\text { O. sanctum EO exhibited antimicrobial activities } \\
\text { against all tested pathogens at concentrations of } \\
0.125-32 \mu \mathrm{L} / \mathrm{mL} \text { except } P \text {. aeruginosa. }\end{array}$ & [208] \\
\hline Ocimum suave & $\mathrm{EO}$ & $\begin{array}{l}\text { S. aureus, S. epidermidis, S. mutans, S. viridans, } \\
\text { E. coli, E. cloacae, K. pneumoniae, P. aeruginosa, } \\
\text { C. albicans, C. tropicalis, C. glabrata }\end{array}$ & $\begin{array}{l}\text { O. suave EO showed the strongest antibacterial } \\
\text { activities with MICs ranging from } 0.05 \text { to } 1.37 \\
\mathrm{mg} / \mathrm{mL} \text {. }\end{array}$ & [209] \\
\hline Olea europaea L. & Methanol extract & $\begin{array}{l}\text { S. aureus, S. epidermidis, S. pyogenes, Streptococcus } \\
\text { agalactiae, S. enterica serovar Typhi, P. aeruginosa, } \\
\text { Acetobacter calcoaceticus, C. albicans, P. vulgaris, } \\
\text { S. faecalis, S. dysenteriae, K. pneumoniae, E. coli, } \\
\text { V. cholera, C. xerosis }\end{array}$ & $\begin{array}{l}\text { O. europaea methanol extract showed strong } \\
\text { antibacterial activities against } S \text {. aureus, } \\
\text { S. epidermidis, and S. pyogenes at MICs range of } \\
31.25-62.5 \mu \mathrm{g} / \mathrm{mL} \text {. }\end{array}$ & [210] \\
\hline Origanum marjorana & Water extract & Vibrio parahaemolyticus & $\begin{array}{l}\text { O. marjorana showed the lowest MICs against } \\
V . \text { parahaemolyticus both in a nutrient rich and poor } \\
\text { medium. }\end{array}$ & [211] \\
\hline Origanum minutiflorum & $\mathrm{EO}$ & $\begin{array}{l}\text { E. coli, S. aureus, S. enteritidis, L. monocytogenes, } \\
\text { L. plantarum }\end{array}$ & $\begin{array}{l}\text { Whey protein based edible films incorporated with } \\
\text { O. minutiflorum EO was the most effective at } 2 \% \\
\text { level. }\end{array}$ & [212] \\
\hline $\begin{array}{l}\text { Orthosiphon stamineus } \\
\text { Benth. }\end{array}$ & $\begin{array}{l}\text { Methanol and aqueous } \\
\text { extracts }\end{array}$ & V. parahaemolyticus & $\begin{array}{l}\text { V. parahaemolyticus was more susceptible to } \\
50-100 \% \text { methanol extracts of O. stamineus. }\end{array}$ & [213] \\
\hline
\end{tabular}


Table 15. Cont.

\begin{tabular}{|c|c|c|c|c|}
\hline Spices & Type of Samples & Bacteria and Fungi & Main Results & Reference \\
\hline Peganum harmala L. & Methanol extract & $\begin{array}{l}\text { S. aureus, S. epidermidis, S. pyogenes, S. agalactiae, } \\
\text { S. enterica serovar Typhi, P. aeruginosa, Acetobacter } \\
\text { calcoaceticus, C. albicans, P. vulgaris, S. faecalis, } \\
\text { S. dysenteriae, K. pneumoniae, E. coli, V. cholera, C. } \\
\text { xerosis }\end{array}$ & $\begin{array}{l}\text { P. harmala seed showed MICs of } 31.25-62.5,250, \\
125-250 \text {, and } 31.25-250 \mu \mathrm{g} / \mathrm{mL} \text {, respectively for } S \text {. } \\
\text { aureus, S. enterica serovar Typhi, Acetobacter } \\
\text { calcoaceticus, and C. albicans. }\end{array}$ & [210] \\
\hline Pimenta dioica $\mathrm{L}$. & $\begin{array}{l}\text { Alcoholic and hexane } \\
\text { extracts }\end{array}$ & P. fluorescens, B. megaterium, A. niger, Penicillium sp. & $\begin{array}{l}\text { Alcoholic and hexane extracts of } P \text {. dioica exerted } \\
\text { significant inhibitory effects on both the bacteria } \\
\text { and fungi. }\end{array}$ & [214] \\
\hline Pimpinella anisum $\mathrm{L}$. & EO of fruit & A. alternate, $A$. niger, $A$. parasiticus & $\begin{array}{l}\text { The most sensitive fungus for } P \text {. anisum oil was } \\
\text { A. parasiticus. }\end{array}$ & [215] \\
\hline Pimpinella anisum $\mathrm{L}$. & $\mathrm{EO}$ & 16 microorganisms & $\begin{array}{l}\text { P. anisum EO exhibited strong antifungal activities } \\
\text { against } R \text {. glutinis, A. ochraceus, and F. moniliforme. }\end{array}$ & [78] \\
\hline Pimpinella anisum $\mathrm{L}$. & $\mathrm{EO}$ & $\begin{array}{l}\text { C. lipolytica, } \text { H. uvarum, Pichia membranaefaciens, } \\
\text { R. glutinis, S. pombe, Z. rouxii, A. flavus, A. ochraceus, } \\
\text { A. parasiticus, F. moniliforme }\end{array}$ & $\begin{array}{l}\text { P. anisum EO completely inhibited the growth of } \\
\text { tested fungi. }\end{array}$ & [78] \\
\hline Piper capense & $\mathrm{EO}$ & S. aureus, E. faecalis, C. albicans & $\begin{array}{l}\text { P. capense showed moderate activities against } \\
\text { tested microorganisms. }\end{array}$ & [216] \\
\hline Piper guineense & powder & $\begin{array}{l}\text { B. cereus, Bacillus coagulans, B. enterobacter sp., } \\
\text { A. niger, R. stolonifer }\end{array}$ & $\begin{array}{l}\text { P. guineense inhibited R. stolonifer at concentrations } \\
\text { above } 0.5 \% \text {. }\end{array}$ & [217] \\
\hline Phlomis oppositiflora & $\begin{array}{l}\text { Methanol, ethanol, ethyl } \\
\text { acetate extracts and EO }\end{array}$ & $\begin{array}{l}\text { E. coli, S. aureus, K. pneumonia, M. smegmatis, } \\
\text { P. aeruginosa, E. cloacae, B. megaterium, M. luteus, } \\
\text { R. rubra, C. albicans, K. marxianus }\end{array}$ & $\begin{array}{l}\text { P. oppositiflora contains antimicrobial components } \\
\text { against various microorganisms. }\end{array}$ & [218] \\
\hline Ramalina species & $\begin{array}{l}\text { Acetone, methanol and } \\
\text { ethanol extracts }\end{array}$ & E. coli and S. aureus & $\begin{array}{l}\text { The MICs of all extracts ranged from } 64 \text { to } 512 \\
\mathrm{~g} / \mathrm{mL} \text { for all bacterial strains tested. }\end{array}$ & [219] \\
\hline Rhus coriaria $\mathrm{L}$. & $\begin{array}{l}80 \%(v / v) \text { aqueous alcohol } \\
\text { extract }\end{array}$ & $\begin{array}{l}\text { S. aureus, B. cereus, E. coli, S. typhimurium, } \\
\text { P. vulgaris, S. flexneri }\end{array}$ & $\begin{array}{l}\text { The MICs of } R \text {. coriaria extract against the tested } \\
\text { bacteria ranged from } 0.04 \% \text { to } 0.2 \% \text {. }\end{array}$ & [220] \\
\hline Rhus coriaria & Water extract & B. cereus, L. monocytogenes, E. coli, S. typhimurium & $\begin{array}{l}R \text {. coriaria extract was the most effective against } \\
\text { the four bacteria tested. }\end{array}$ & [221] \\
\hline Salvia officinalis $\mathrm{L}$. & $\mathrm{EO}$ & 13 bacterial strains and 6 fungi & $\begin{array}{l}\text { Sage EO was more effective against E. coli, } S . \\
\text { typhimurium, S. enteritidis, and S. sonei. }\end{array}$ & [92] \\
\hline $\begin{array}{l}\text { Salvia officinalis L. } \\
\text { (sage) }\end{array}$ & $80 \%$ ethanol extract & $\begin{array}{l}\text { Campylobacter coli, E. coli, Streptococcus infantis, } \\
\text { B. cereus, L. monocytogenes, S. aureus }\end{array}$ & $\begin{array}{l}\text { Sage extract showed the best antibacterial activities } \\
\text { compared with four other plants, especially } \\
\text { against Gram-positive bacteria and C. coli. }\end{array}$ & [222] \\
\hline
\end{tabular}


Table 15. Cont.

\begin{tabular}{|c|c|c|c|c|}
\hline Spices & Type of Samples & Bacteria and Fungi & Main Results & Reference \\
\hline Salvia officinalis L. & $\mathrm{EO}$ & E. coli, $P$. aeruginosa, Enterobacter sp., S. aureus & $\begin{array}{l}\text { Microwave-EO of S. officinalis possessed good } \\
\text { antibacterial activities than the hydrodistilled oil. }\end{array}$ & [223] \\
\hline Salvia leriifolia & Methanol extract & S. aureus & $\begin{array}{l}\text { S. leriifolia extract exhibited antimicrobial activity } \\
\text { against } S \text {. aureus. }\end{array}$ & [224] \\
\hline $\begin{array}{l}\text { Santolina } \\
\text { chamaecyparissus L. }\end{array}$ & $\mathrm{EO}$ & K. pneumonia and C. albicans & $\begin{array}{l}\text { S. chamaecyparissus } \mathrm{EO} \text { was very active against the } \\
\text { two microorganisms listed. }\end{array}$ & [225] \\
\hline Satureja cuneifolia Ten. & $\mathrm{EO}$ & $\begin{array}{l}\text { E. coli, Campylobacter jejuni, S. sonnei, S. aureus, } \\
\text { L. monocytogenes, B. cereus, P. aeruginosa, } \\
\text { S. enteritidis }\end{array}$ & $\begin{array}{l}\text { MICs of S. cuneifolia EO for tested bacteria were in } \\
\text { the range of } 600-1400 \mu \mathrm{g} / \mathrm{mL} \text {. }\end{array}$ & [226] \\
\hline Satureja kitaibelii & $\mathrm{EO}$ & 30 pathogenic microorganisms & $\begin{array}{l}\text { S. kitaibelii EO showed significant activities against } \\
\text { foodborne microbes (MIC: } 0.18-25.5 \mu \mathrm{g} / \mathrm{mL} \text { ), } \\
\text { multiresistant bacterial isolates (MIC: } 6.25-50.0 \\
\mu \mathrm{g} / \mathrm{mL} \text { ), and dermatophyte strains (MIC: } \\
12.5-50.0 \mu \mathrm{g} / \mathrm{mL} \text { ). }\end{array}$ & [227] \\
\hline Satureja wiedemanniana & $\mathrm{EO}$ & 37 Bacillus strains & $\begin{array}{l}\text { Both S. wiedemanniana } \mathrm{EO} \text { and its main component } \\
\text { p-cymene exhibited strong antimicrobial activities } \\
\text { against some Bacillus strains. }\end{array}$ & [228] \\
\hline Satureja species & EOs & $\begin{array}{l}\text { A. niger, Penicillium digitatum, B. cinerea, } \\
\text { R. stolonifer }\end{array}$ & $\begin{array}{l}\text { The EOs exhibited fungicidal activities against } \\
P \text {. digitatum, B. cinereal, and } R \text {. stolonifer. }\end{array}$ & [229] \\
\hline Silene laxa & $\begin{array}{l}\text { Ethyl acetate, chloroform, } \\
\text { methanol, ethanol and } \\
\text { acetone extract }\end{array}$ & $\begin{array}{l}\text { P. aeruginosa, E. cloacae, B. megaterium, E. cloacae, } \\
\text { S. aureus }\end{array}$ & $\begin{array}{l}\text { S. laxa leaves ethanol extract showed the best } \\
\text { activities against } P \text {. aeruginosa, E. cloacae, } \\
\text { B. megaterium, while the methanol extracts of } S \text {. } \\
\text { laxa fruits showed the best antibacterial activity } \\
\text { against B.megaterium. }\end{array}$ & [230] \\
\hline Summer savory & - & A. niger, A. alternate, A. parasiticus & $\begin{array}{l}0.5 \% \text { summer savory extract showed } 100 \% \\
\text { inhibition till the seventh day of incubation. }\end{array}$ & [231] \\
\hline $\begin{array}{l}\text { Syzygium aromaticum } \\
\text { L. }\end{array}$ & Water extract & $\begin{array}{l}\text { S. aureus, S. epidermidis, S. pyogenes, S. agalactiae, } \\
\text { S. enterica serovar Typhi, P. aeruginosa, Acetobacter } \\
\text { calcoaceticus, C. albicans, P. vulgaris, S. faecalis, } \\
\text { S. dysenteriae, K. pneumoniae, E. coli, V. cholera, } \\
\text { C. xerosis }\end{array}$ & $\begin{array}{l}\text { S. aromaticum water extract showed antibacterial } \\
\text { activities with MICs in the range of } 31.25-250 \\
\mu \mathrm{g} / \mathrm{mL} \text { for } S \text {. aureus, S. epidermidis, S. pyogenes, } \\
\text { S. enterica serovar Typhi, Acetobacter calcoaceticus, } \\
\text { and P. aeruginosa. }\end{array}$ & [210] \\
\hline Thymbra spicata $\mathrm{L}$. & Decoction & $\begin{array}{l}\text { F. oxysporum f. sp. phaseoli, M. phaseoli, B. cinerea, } \\
\text { R. solani, A. solani, A. parasiticus }\end{array}$ & $\begin{array}{l}\text { T. spicata completely inhibited the mycelial growth } \\
\text { of fungi and showed a complete fungicidal effect } \\
\text { on molds. }\end{array}$ & [39] \\
\hline
\end{tabular}


Table 15. Cont.

\begin{tabular}{|c|c|c|c|c|}
\hline Spices & Type of Samples & Bacteria and Fungi & Main Results & Reference \\
\hline Thymus capitata & $\mathrm{EO}$ & L. monocytogenes & MICs ranged from 0.32 to $20 \mathrm{mg} / \mathrm{mL}$. & [232] \\
\hline Thymus capitatus & $\mathrm{EO}$ & $\begin{array}{l}\text { L. innocua, S. marcescens, P. fragi, P. fluorescens, } \\
\text { A. hydrophila, Shewanella putrefaciens, Achromobacter } \\
\text { denitrificans, E. amnigenus, E. gergoviae, Alcaligenes } \\
\text { faecalis, Leuconostoc carnosum }\end{array}$ & $\begin{array}{l}\text { T. capitatus EOs showed inhibitory effects on the } \\
10 \text { tested bacteria with MICs ranging from } 1.87 \text { to } \\
7.5 \mu \mathrm{L} / \mathrm{mL} \text {. }\end{array}$ & [233] \\
\hline $\begin{array}{l}\text { Thymus cappadocicus } \\
\text { Boiss. }\end{array}$ & $\mathrm{EO}$ & 13 bacteria and 2 yeasts & $\begin{array}{l}\text { T. cappadocicus EO showed great antimicrobial } \\
\text { activities against microorganisms tested. }\end{array}$ & [234] \\
\hline Thymus eigii & $\mathrm{EO}$ & $\begin{array}{l}\text { M. luteus, B. megaterium, B. brevis, E. faecalis, } \\
\text { P. pyocyaneus, M. smegmatis, E. coli, A. hydrophila, } \\
\text { Y. enterocolitica, S. aureus, S. faecalis, S. cerevisiae, K. } \\
\text { fragilis }\end{array}$ & $\begin{array}{l}\text { T. eigii EO showed the highest antimicrobial } \\
\text { activities compared with two other plants. }\end{array}$ & [235] \\
\hline Thymus piperella & $\mathrm{EO}$ & $\begin{array}{l}\text { L. innocua, S. marcescens, } P \text {. fragi, } P \text {. fluorescens, } \\
\text { A. hydrophila, S. putrefaciens, A. denitrificans, } \\
\text { E. amnigenus, E. gergoviae, A. faecalis, L. carnosum }\end{array}$ & $\begin{array}{l}\text { T. piperella } \mathrm{EO} \text { had inhibitory effects on } 5 \text { of the } 11 \\
\text { bacteria tested. }\end{array}$ & [236] \\
\hline Thymus serpyllum & $\mathrm{EO}$ & Penicillium sp., Alternaria sp., Aureobasidium sp. & $\begin{array}{l}8 \mathrm{mg} / \text { disc EO of } T \text {. serpyllum has a good efficiency } \\
\text { by inhibiting the germination of spores from } 80 \% \\
\text { to } 100 \% \text {. }\end{array}$ & [237] \\
\hline Trachyspermum ammi L. & $\mathrm{EO}$ & $\begin{array}{l}\text { A. niger, A. flavus, A. oryzae, A. ochraceus, } \\
\text { F. monoliforme, F. graminearum, Pencillium citrium, } \\
\text { P. viridicatum, P. madriti, C. lunata }\end{array}$ & $\begin{array}{l}\text { T. ammi EO exhibited a broad spectrum of fungi } \\
\text { toxic behavior against all tested fungi. }\end{array}$ & [238] \\
\hline Xylopia aethiopica & - & Sclerotium rolfsii & $\begin{array}{l}\text { X. aethiopica extract was the most effective against } \\
\text { S. rolfsii compared with four other spices. }\end{array}$ & [239] \\
\hline Zanthoxylum piperitum & Polymeric procyanidin & S. aureus & $\begin{array}{l}\text { A polymeric proanthocyanidin purified from the } \\
\text { fruit of } Z \text {. piperitum, noticeably decreased the MICs } \\
\text { of } \beta \text {-lactam antibiotics for MRSA. }\end{array}$ & [240] \\
\hline $\begin{array}{l}\text { Zanthoxylum } \\
\text { schinifolium }\end{array}$ & $\mathrm{EO}$ & $\begin{array}{l}\text { S. aureus, S. epidermidis, B. subtilis, S. typhimurium, } \\
\text { P. aeruginosa, S. dysenteriae, E. coli }\end{array}$ & $\begin{array}{l}\text { Z. schinifolium EO was particularly strong against } \\
\text { S. epidermidis, with MIC } 2.5 \mathrm{mg} / \mathrm{mL} \text {. }\end{array}$ & [241] \\
\hline Zataria multiflora Boiss. & $\begin{array}{l}80 \%(v / v) \text { aqueous alcohol } \\
\text { extract }\end{array}$ & $\begin{array}{l}\text { S. aureus, B. cereus, E. coli, S. typhimurium, } \\
\text { P. vulgaris, S. flexneri }\end{array}$ & $\begin{array}{l}\text { The MICs of } Z \text {. multiflora against the tested } \\
\text { bacteria ranged from } 0.4 \% \text { to } 0.8 \% \text {. }\end{array}$ & [220] \\
\hline
\end{tabular}




\section{Conclusions}

The antibacterial and antifungal activities of commonly used spices have been summarized. Several spices—-such as clove, oregano, thyme, cinnamon, and cumin-have exhibited significant antimicrobial activities against food spoilage bacteria like $B$. subtilis and $P$. fluorescens; pathogens like S. aureus, V. parahaemolyticus, and S. typhimurium; harmful fungi like A. flavus and A. niger; and even antibiotic resistant microorganisms such as MRSA. Therefore, these spices could be used to decrease the possibility of food poisoning and spoilage, to increase the food safety and shelf-life of products, and to treat some infectious diseases. In the future, as the combinations of several spices were proven to possess higher inhibitory effects on specific bacteria than those of individual spices, the interactions of more spices should be studied and evaluated to inhibit different microorganisms in different food products. Additionally, spices could be used in food packaging as published, but more studies are required to take the other aspects into consideration, such as how to prevent odor/flavor transferring from packages containing natural spice extracts to the packaged foods. Furthermore, spice products may be considered as an alternative to common antibiotics to treat infectious diseases. As the majority of the studies focused on the in vitro activities of spices against human pathogenic bacteria, in vivo studies and clinical trials are needed to be conducted in future. The mechanisms of antimicrobial action of spices remain to be clarified in order to make the best use of spices. Furthermore, the potential toxicity of spices on humans should be evaluated.

Acknowledgments: This work was supported by the National Natural Science Foundation of China (No. 81372976), Key Project of Guangdong Provincial Science and Technology Program (No. 2014B020205002), and the Hundred-Talents Scheme of Sun Yat-Sen University.

Author Contributions: Qing Liu and Hua-Bin Li conceived this paper; Qing Liu, Xiao Meng, Ya Li, Cai-Ning Zhao, and Guo-Yi Tang wrote this paper; Hua-Bin Li revised the paper.

Conflicts of Interest: The authors declare no conflict of interest.

\section{References}

1. Miladi, H.; Zmantar, T.; Chaabouni, Y.; Fedhila, K.; Bakhrouf, A.; Mandouani, K.; Chaieb, K. Antibacterial and efflux pump inhibitors of thymol and carvacrol against food-borne pathogens. Microb. Pathog. 2016, 99, 95-100. [CrossRef] [PubMed]

2. Brul, S.; Coote, P. Preservative agents in foods. Mode of action and microbial resistance mechanisms. Int. J. Food Microbiol. 1999, 50, 1-17. [CrossRef]

3. De Souza, E.L.; Stamford, T.; Lima, E.D.; Trajano, V.N.; Barbosa, J.M. Antimicrobial effectiveness of spices: An approach for use in food conservation systems. Braz. Arch. Biol. Technol. 2005, 48, 549-558. [CrossRef]

4. Silva, F.; Domingues, F.C. Antimicrobial activity of coriander oil and its effectiveness as food preservative. Crit. Rev. Food Sci. Nutr. 2017, 57, 35-47. [CrossRef] [PubMed]

5. Tajkarimi, M.M.; Ibrahim, S.A.; Cliver, D.O. Antimicrobial herb and spice compounds in food. Food Control 2010, 21, 1199-1218. [CrossRef]

6. Nabavi, S.M.; Marchese, A.; Izadi, M.; Curti, V.; Daglia, M.; Nabavi, S.F. Plants belonging to the genus Thymus as antibacterial agents: From farm to pharmacy. Food Chem. 2015, 173, 339-347. [CrossRef] [PubMed]

7. Marchese, A.; Barbieri, R.; Sanches-Silva, A.; Daglia, M.; Nabavi, S.F.; Jafari, N.J.; Izadi, M.; Ajami, M.; Nabavi, S.M. Antifungal and antibacterial activities of allicin: A review. Trends Food Sci. Technol. 2016, 52, 49-56. [CrossRef]

8. Paphitou, N.I. Antimicrobial resistance: Action to combat the rising microbial challenges. Int. J. Antimicrob. Agents 2013, 42, S25-S28. [CrossRef] [PubMed]

9. Högberg, L.D.; Heddini, A.; Cars, O. The global need for effective antibiotics: Challenges and recent advances. Trends Pharmacol. Sci. 2010, 31, 509-515. [CrossRef] [PubMed]

10. Lai, P.K.; Roy, J. Antimicrobial and chemopreventive properties of herbs and spices. Curr. Med. Chem. 2004, 11, 1451-1460. [CrossRef] [PubMed] 
11. Nabavi, S.F.; di Lorenzo, A.; Izadi, M.; Sobarzo-Sánchez, E.; Daglia, M.; Nabavi, S.M. Antibacterial effects of cinnamon: From farm to food, cosmetic and pharmaceutical industries. Nutrients 2015, 7, 7729-7748. [CrossRef] [PubMed]

12. Zheng, J.; Zhou, Y.; Li, Y.; Xu, D.P.; Li, S.; Li, H.B. Spices for prevention and treatment of cancers. Nutrients 2016, 8, 495. [CrossRef] [PubMed]

13. De, M.; De, A.K.; Banerjee, A.B. Antimicrobial screening of some Indian spices. Phytother. Res. 1999, 13, 616-618. [CrossRef]

14. Arora, D.S.; Kaur, J. Antimicrobial activity of spices. Int. J. Antimicrob. Agents 1999, 12, 257-262. [CrossRef]

15. Chaieb, K.; Hajlaoui, H.; Zmantar, T.; Kahla-Nakbi, A.B.; Rouabhia, M.; Mahdouani, K.; Bakhrouf, A. The chemical composition and biological activity of clove essential oil, Eugenia caryophyllata (Syzigium aromaticum L. Myrtaceae): A short review. Phytother. Res. 2007, 21, 501-506. [CrossRef] [PubMed]

16. Xu, J.G.; Liu, T.; Hu, Q.P.; Cao, X.M. Chemical composition, antibacterial properties and mechanism of action of essential oil from clove buds against Staphylococcus aureus. Molecules 2016, 21, 1194. [CrossRef] [PubMed]

17. Lomarat, P.; Phanthong, P.; Wongsariya, K.; Chomnawang, M.T.; Bunyapraphatsara, N. Bioautography-guided isolation of antibacterial compounds of essential oils from Thai spices against histamine-producing bacteria. Pak. J. Pharm. Sci. 2013, 26, 473-477. [PubMed]

18. Nassan, M.A.; Mohamed, E.H.; Abdelhafez, S.; Ismail, T.A. Effect of clove and cinnamon extracts on experimental model of acute hematogenous pyelonephritis in albino rats: Immunopathological and antimicrobial study. Int. J. Immunopathol. Pharmacol. 2015, 28, 60-68. [CrossRef] [PubMed]

19. Kuang, X.; Li, B.; Kuang, R.; Zheng, X.D.; Zhu, B.; Xu, B.L.; Ma, M.H. Granularity and antibacterial activities of ultra-fine cinnamon and clove powders. J. Food Saf. 2011, 31, 291-296. [CrossRef]

20. Burt, S. Essential oils: Their antibacterial properties and potential applications in foods-A review. Int. J. Food Microbiol. 2004, 94, 223-253. [CrossRef] [PubMed]

21. Badei, A.; Faheld, S.; El-Akel, A.; Mahmoud, B. Application of some spices in flavoring and preservation of cookies: 2-Antimicrobial and sensory properties of cardamom, cinnamon and clove. Dtsch. Lebensm. Rundsch. 2002, 98, 261-265.

22. Schmidt, E.; Jirovetz, L.; Wlcek, K.; Buchbauer, G.; Gochev, V.; Girova, T.; Stoyanova, A.; Geissler, M. Antifungal activity of eugenol and various eugenol-containing essential oils against 38 clinical isolates of Candida albicans. J. Essent. Oil Bear. Plants 2007, 10, 421-429. [CrossRef]

23. Angienda, P.O.; Onyango, D.M.; Hill, D.J. Potential application of plant essential oils at sub-lethal concentrations under extrinsic conditions that enhance their antimicrobial effectiveness against pathogenic bacteria. Afr. J. Microbiol. Res. 2010, 4, 1678-1684.

24. Shan, B.; Cai, Y.Z.; Brooks, J.D.; Corke, H. Antibacterial and antioxidant effects of five spice and herb extracts as natural preservatives of raw pork. J. Sci. Food Agric. 2009, 89, 1879-1885. [CrossRef]

25. Bayoub, K.; Baibai, T.; Mountassif, D.; Retmane, A.; Soukri, A. Antibacterial activities of the crude ethanol extracts of medicinal plants against Listeria monocytogenes and some other pathogenic strains. Afr. J. Biotechnol. 2010, 9, 4251-4258.

26. Cui, H.Y.; Gabriel, A.A.; Nakano, H. Antimicrobial efficacies of plant extracts and sodium nitrite against Clostridium botulinum. Food Control 2010, 21, 1030-1036. [CrossRef]

27. Keskin, D.; Toroglu, S. Studies on antimicrobial activities of solvent extracts of different spices. J. Environ. Biol. 2011, 32, 251-256. [PubMed]

28. Liang, Z.W.; Cheng, Z.H.; Mittal, G.S. Inactivation of microorganisms in apple cider using spice powders, extracts and oils as antimicrobials with and without low-energy pulsed electric field. J. Food Agric. Environ. 2003, 1, 28-33.

29. Badhe, S.R.; Fairoze, M.N. Antibacterial efficacy of clove powder of chicken legs spiked with pathogenic reference strains under refrigeration temperature $\left(8 \pm 2{ }^{\circ} \mathrm{C}\right)$. Indian J. Anim. Res. 2012, 46, 371-375.

30. Hernández-Ochoa, L.; Gonzales-Gonzales, A.; Gutierrez-Mendez, N.; Munoz-Castellanos, L.N.; Quintero-Ramos, A. Study of the antibacterial activity of chitosan-based films prepared with different molecular weights including spices essential oils and functional extracts as antimicrobial agents. Rev. Mex. Ing. Quim. 2011, 10, 455-463.

31. Hernández-Ochoa, L.; Macías-Castañeda, C.A.; Nevárez-Moorillón, G.V.; Salas-Muñoz, E.; Sandoval-Salas, F. Antimicrobial activity of chitosan-based films including spices' essential oils and functional extracts. CyTA J. Food 2012, 10, 85-91. [CrossRef] 
32. Liu, G.Q.; Zhang, L.L.; Zong, K.; Wang, A.M.; Yu, X.F. Effects of spices essential oils on the spoilage-related microbiota in chilled pork stored in antimicrobial pack. Food Sci. Technol. Res. 2012, 18, 695-704. [CrossRef]

33. Rodriguez-Garcia, I.; Silva-Espinoza, B.A.; Ortega-Ramirez, L.A.; Leyva, J.M.; Siddiqui, M.W.; Cruz-Valenzuela, M.R.; Gonzalez-Aguilar, G.A.; Ayala-Zavala, J.F. Oregano essential oil as an antimicrobial and antioxidant additive in food products. Crit. Rev. Food Sci. Nutr. 2016, 56, 1717-1727. [CrossRef] [PubMed]

34. Babacan, O.; Cengiz, S.; Akan, M. Detection of antibacterial effect of oregano plant on various Salmonella serotypes. Ank. Univ. Vet. Fak. Derg. 2012, 59, 103-106.

35. Santoyo, S.; Cavero, S.; Jaime, L.; Ibanez, E.; Senorans, F.J.; Reglero, G. Supercritical carbon dioxide extraction of compounds with antimicrobial activity from Origanum vulgare L.: Determination of optimal extraction parameters. J. Food Prot. 2006, 69, 369-375. [CrossRef] [PubMed]

36. De Souza, E.L.; Stamford, T.; Lima, E.; Barbosa, J.M.; Marques, M. Interference of heating on the antimicrobial activity and chemical composition of Origanum vulgare L. (Lamiaceae) essential oil. Cienc. Tecnol. Aliment. 2008, 28, 418-422. [CrossRef]

37. Lima, I.O.; Pereira, F.D.O.; de Oliveira, W.A.; Lima, E.D.O.; Menezes, E.A.; Cunha, F.A.; Formiga Melo Diniz, M.D.F. Antifungal activity and mode of action of carvacrol against Candida albicans strains. J. Essent. Oil Res. 2013, 25, 138-142. [CrossRef]

38. Ultee, A.; Kets, E.; Smid, E.J. Mechanisms of action of carvacrol on the food-borne pathogen Bacillus cereus. Appl. Environ. Microb. 1999, 65, 4606-4610.

39. Ozcan, M.; Boyraz, N. Antifungal properties of some herb decoctions. Eur. Food Res. Technol. 2000, 212, 86-88.

40. Ai-Turki, A.I.; Ei-Ziney, M.G.; Abdel-Salam, A.M. Chemical and anti-bacterial characterization of aqueous extracts of oregano, marjoram, sage and licorice and their application in milk and labneh. J. Food Agric. Environ. 2008, 6, 39-44.

41. Marques, J.D.; Volcao, L.M.; Funck, G.D.; Kroning, I.S.; da Silva, W.P.; Fiorentini, A.M.; Ribeiro, G.A. Antimicrobial activity of essential oils of Origanum vulgare L. and Origanum majorana L. against Staphylococcus aureus isolated from poultry meat. Ind. Crop. Prod. 2015, 77, 444-450. [CrossRef]

42. Bozin, B.; Mimica-Dukic, N.; Simin, N.; Anackov, G. Characterization of the volatile composition of essential oils of some Lamiaceae spices and the antimicrobial and antioxidant activities of the entire oils. J. Agric. Food Chem. 2006, 54, 1822-1828. [CrossRef] [PubMed]

43. Viuda-Martos, M.; Ruiz-Navajas, Y.; Fernández-López, J.; Pérez-Álvarez, J.A. Antibacterial activity of different essential oils obtained from spices widely used in Mediterranean diet. Int. J. Food Sci. Technol. 2008, 43, 526-531. [CrossRef]

44. Santurio, D.F.; da Costa, M.M.; Maboni, G.; Cavalheiro, C.P.; de Sá, M.F.; Dal Pozzo, M.; Alves, S.H.; Fries, L. Antimicrobial activity of spice essential oils against Escherichia coli strains isolated from poultry and cattle. Cienc. Rural 2011, 41, 1051-1056. [CrossRef]

45. Khosravi, A.R.; Shokri, H.; Kermani, S.; Dakhili, M.; Madani, M.; Parsa, S. Antifungal properties of Artemisia sieberi and Origanum vulgare essential oils against Candida glabrata isolates obtained from patients with vulvovaginal candidiasis. J. Mycol. Med. 2011, 21, 93-99. [CrossRef]

46. Dal Pozzo, M.; Viégas, J.; Santurio, D.F.; Rossatto, L.; Soares, I.H.; Alves, S.H.; da Costa, M.M. Antimicrobial activities of essential oils extracted from spices against Staphylococcus spp. isolated from goat mastitis. Cienc. Rural 2011, 41, 667-672. [CrossRef]

47. Santos, J.C.; Carvalho, C.D.; Barros, T.F.; Guimaraes, A.G. In vitro antimicrobial activity of essential oils from oregano, garlic, clove and lemon against pathogenic bacteria isolated from Anomalocardia brasiliana. Semin. Cienc. Agrar. 2011, 32, 1557-1564.

48. Hyun, J.E.; Bae, Y.M.; Song, H.; Yoon, J.H.; Lee, S.Y. Antibacterial effect of various essential oils against pathogens and spoilage microorganisms in fresh produce. J. Food Saf. 2015, 35, 206-219. [CrossRef]

49. Zivanovic, S.; Chi, S.; Draughon, A.F. Antimicrobial activity of chitosan films enriched with essential oils. J. Food Sci. 2005, 70, M45-M51. [CrossRef]

50. Assiri, A.M.A.; Elbanna, K.; Abulreesh, H.H.; Ramadan, M.F. Bioactive compounds of cold-pressed thyme (Thymus vulgaris) oil with antioxidant and antimicrobial properties. J. Oleo Sci. 2016, 65, 629-640. [CrossRef] [PubMed] 
51. Al Maqtari, M.; Alghalibi, S.M.; Alhamzy, E.H. Chemical composition and antimicrobial activity of essential oil of Thymus vulgaris from Yemen. Turk. J. Biochem. 2011, 36, 342-349.

52. Marino, M.; Bersani, C.; Comi, G. Antimicrobial activity of the essential oils of Thymus vulgaris L. measured using a bioimpedometric method. J. Food Prot. 1999, 62, 1017-1023. [CrossRef] [PubMed]

53. Varga, E.; Bardocz, A.; Belak, A.; Maraz, A.; Boros, B.; Felinger, A.; Boszormenyi, A.; Horvath, G. Antimicrobial activity and chemical composition of thyme essential oils and the polyphenolic content of different thymus extracts. Farmacia 2015, 63, 357-361.

54. Tiwari, B.K.; Valdramidis, V.P.; O’Donnell, C.P.; Muthukumarappan, K.; Bourke, P.; Cullen, P.J. Application of natural antimicrobials for food preservation. J. Agric. Food Chem. 2009, 57, 5987-6000. [CrossRef] [PubMed]

55. Al-Turki, A.I. Antibacterial effect of thyme, peppermint, sage, black pepper and garlic hydrosols against Bacillus subtilis and Salmonella enteritidis. J. Food Agric. Environ. 2007, 5, 92-94.

56. Hussien, J.; Teshale, C.; Mohammed, J. Assessment of the antimicrobial effects of some ethiopian aromatic spice and herb hydrosols. Int. J. Pharmacol. 2011, 7, 635-640. [CrossRef]

57. Girova, T.; Gochev, V.; Jirovetz, L.; Buchbauer, G.; Schmidt, E.; Stoyanova, A. Antimicrobial activity of essential oils from spices against psychrotrophic food spoilage microorganisms. Biotechnol. Biotechnol. Equip. 2010, 24, 547-552. [CrossRef]

58. Hajlaoui, H.; Snousi, M.; Noumi, E.; Zaneti, S.; Ksouri, R.; Bakhrouf, A. Chemical composition, antioxidant and antibacterial activities of the essential oils of five Tunisian aromatic plants. Ital. J. Food Sci. 2010, 22, 320-329.

59. Viuda-Martos, M.; Mohamady, M.A.; Fernández-López, J.; Abd ElRazik, K.A.; Omer, E.A.; Perez-Alvarez, J.A.; Sendra, E. In vitro antioxidant and antibacterial activities of essentials oils obtained from Egyptian aromatic plants. Food Control 2011, 22, 1715-1722. [CrossRef]

60. Aliakbarlu, J.; Shameli, F. In vitro antioxidant and antibacterial properties and total phenolic contents of essential oils from Thymus vulgaris, T. Kotschyanus, Ziziphora tenuior and Z. Clinopodioides. Turk. J. Biochem. 2013, 38, 425-431. [CrossRef]

61. Bagamboula, C.F.; Uyttendaele, M.; Debevere, J. Antimicrobial effect of spices and herbs on Shigella sonnei and Shigella flexneri. J. Food Prot. 2003, 66, 668-673. [CrossRef] [PubMed]

62. Martins, N.; Barros, L.; Santos-Buelga, C.; Silva, S.; Henriques, M.; Ferreira, I. Decoction, infusion and hydroalcoholic extract of cultivated thyme: Antioxidant and antibacterial activities, and phenolic characterisation. Food Chem. 2015, 167, 131-137. [CrossRef] [PubMed]

63. Ozturk, I. Antifungal activity of propolis, thyme essential oil and hydrosol on natural mycobiota of sucuk, a turkish fermented sausage: Monitoring of their effects on microbiological, color and aroma properties. J. Food Process Preserv. 2015, 39, 1148-1158. [CrossRef]

64. Aman, S.; Naim, A.; Siddiqi, R.; Naz, S. Antimicrobial polyphenols from small tropical fruits, tea and spice oilseeds. Food Sci. Technol. Int. 2014, 20, 241-251. [CrossRef] [PubMed]

65. Aznar, A.; Fernandez, P.S.; Periago, P.M.; Palop, A. Antimicrobial activity of nisin, thymol, carvacrol and cymene against growth of Candida lusitaniae. Food Sci. Technol. Int. 2015, 21, 72-79. [CrossRef] [PubMed]

66. Ranasinghe, P.; Jayawardana, R.; Galappaththy, P.; Constantine, G.R.; de Vas Gunawardana, N.; Katulanda, P. Efficacy and safety of "true" cinnamon (Cinnamomum zeylanicum) as a pharmaceutical agent in diabetes: A systematic review and meta-analysis. Diabet. Med. 2012, 29, 1480-1492. [CrossRef] [PubMed]

67. Khasnavis, S.; Pahan, K. Sodium benzoate, a metabolite of cinnamon and a food additive, upregulates neuroprotective Parkinson disease protein DJ-1 in astrocytes and neurons. J. Neuroimmune Pharm. 2012, 7, 424-435. [CrossRef] [PubMed]

68. Brierley, S.M.; Kelber, O. Use of natural products in gastrointestinal therapies. Curr. Opin. Pharmacol. 2011, 11, 604-611. [CrossRef] [PubMed]

69. Al-Jiffri, O.; El-Sayed, Z.M.F.; Al-Sharif, F.M. Urinary tract infection with Esherichia coli and antibacterial activity of some plants extracts. Int. J. Microbiol. Res. 2011, 2, 1-7.

70. Gupta, C.; Garg, A.P.; Uniyal, R.C.; Kumari, A. Comparative analysis of the antimicrobial activity of cinnamon oil and cinnamon extract on some food-borne microbes. Afr. J. Microbiol. Res. 2008, 2, 247-251.

71. Ceylan, E.; Fung, D.; Sabah, J.R. Antimicrobial activity and synergistic effect of cinnamon with sodium benzoate or potassium sorbate in controlling Escherichia coli O157: H7 in apple juice. J. Food Sci. 2004, 69, M102-M106. [CrossRef] 
72. Cui, H.Y.; Li, W.; Li, C.Z.; Vittayapadung, S.; Lin, L. Liposome containing cinnamon oil with antibacterial activity against methicillin-resistant Staphylococcus aureus biofilm. Biofouling 2016, 32, 215-225. [CrossRef] [PubMed]

73. Shreaz, S.; Wani, W.A.; Behbehani, J.M.; Raja, V.; Irshad, M.; Karched, M.; Ali, I.; Siddiqi, W.A.; Hun, L.T. Cinnamaldehyde and its derivatives, a novel class of antifungal agents. Fitoterapia 2016, 112, 116-131. [CrossRef] [PubMed]

74. Mvuemba, H.N.; Green, S.E.; Tsoomo, A.; Avis, T.J. Antimicrobial efficacy of cinnamon, ginger, horseradish and nutmeg extracts against spoilage pathogens. Phytoprotection 2009, 90, 65-70. [CrossRef]

75. Wang, Q.; Ou, Z.B.; Lei, H.W.; Zeng, X.H.; Ying, Y.; Bai, W.D. Antimicrobial activities of a new formula of spice water extracts against foodborne bacteria. J. Food Process Preserv. 2012, 36, 374-381. [CrossRef]

76. Agaoglu, S.; Dostbil, N.; Alemdar, S. Antimicrobial activity of some spices used in the meat industry. Bull. Vet. Inst. Pulawy 2007, 51, 53-57.

77. Revati, S.; Bipin, C.; Chitra, P.; Minakshi, B. In vitro antibacterial activity of seven Indian spices against high level gentamicin resistant strains of enterococci. Arch. Med. Sci. 2015, 11, 863-868. [CrossRef] [PubMed]

78. Nanasombat, S.; Wimuttigosol, P. Antimicrobial and antioxidant activity of spice essential oils. Food Sci. Biotechnol. 2011, 20, 45-53. [CrossRef]

79. Trajano, V.N.; Lima, E.D.; de Souza, E.L.; Travassos, A. Antibacterial property of spice essential oils on food contaminating bacteria. Ciencia Tecnol. Aliment. 2009, 29, 542-545. [CrossRef]

80. Reza, Z.M.; Atefeh, J.Y.; Faezeh, F. Effect of ã-irradiation on the antibacterial activities of Cuminum cyminum L. essential oils in vitro and in vivo systems. J. Essent. Oil Bear. Plants 2015, 18, 582-591. [CrossRef]

81. Allahghadri, T.; Rasooli, I.; Owlia, P.; Nadooshan, M.J.; Ghazanfari, T.; Taghizadeh, M.; Astaneh, S. Antimicrobial property, antioxidant capacity, and cytotoxicity of essential oil from cumin produced in Iran. J. Food Sci. 2010, 75, H54-H61. [CrossRef] [PubMed]

82. Kedia, A.; Prakash, B.; Mishra, P.K.; Dubey, N.K. Antifungal and antiaflatoxigenic properties of Cuminum cyminum (L.) seed essential oil and its efficacy as a preservative in stored commodities. Int. J. Food Microbiol. 2014, 168, 1-7. [CrossRef] [PubMed]

83. Abd El Mageed, M.A.; Mansour, A.F.; El Massry, K.F.; Ramadan, M.M.; Shaheen, M.S.; Shaaban, H. Effect of microwaves on essential oils of coriander and cumin seeds and on their antioxidant and antimicrobial activities. J. Essent. Oil Bear. Plants 2012, 15, 614-627. [CrossRef]

84. Chaudhry, N.; Tariq, P. In vitro antibacterial activities of kalonji, cumin and poppy seed. Pak. J. Bot. 2008, 40, 461-467.

85. Iacobellis, N.S.; Lo Cantore, P.; Capasso, F.; Senatore, F. Antibacterial activity of Cuminum cyminum L. and Carum carvi L. essential oils. J. Agric. Food Chem. 2005, 53, 57-61. [CrossRef] [PubMed]

86. Ozcan, M.; Erkmen, O. Antimicrobial activity of the essential oils of Turkish plant spices. Eur. Food Res. Technol. 2001, 212, 658-660.

87. Stefanini, M.B.; Figueiredo, R.O.; Ming, L.C.; Junior, A.F. Antimicrobial activity of the essential oils of some spice herbs. In Proceedings of the International Conference on Medicinal and Aromatic Plants Possibilities and Limitations of Medicinal and Aromatic Plant Production in the 21st Century, Budapest, Hungary, 8-11 July 2001; Szoke, E., Mathe, I., Blunden, G., Kery, A., Eds.; International Society for Horticultural Science: Leuven, Belgium, 2003; pp. 215-216.

88. Toroglu, S. In vitro antimicrobial activity and synergistic/antagonistic effect of interactions between antibiotics and some spice essential oils. J. Environ. Biol. 2011, 32, 23-29. [PubMed]

89. Bag, A.; Chattopadhyay, R.R. Evaluation of synergistic antibacterial and antioxidant efficacy of essential oils of spices and herbs in combination. PLoS ONE 2015, 10, e0131321. [CrossRef] [PubMed]

90. Azizkhani, M.; Tooryan, F. Antioxidant and antimicrobial activities of rosemary extract, mint extract and a mixture of tocopherols in beef sausage during storage at 4C. J. Food Saf. 2015, 35, 128-136. [CrossRef]

91. Tavassoli, S.K.; Mousavi, S.M.; Emam-Djomeh, Z.; Razavi, S.H. Chemical composition and evaluation of antimicrobial properties of Rosmarinus officinalis L. essential oil. Afr. J. Biotechnol. 2011, 10, 13895-13899.

92. Bozin, B.; Mlmica-Dukic, N.; Samojlik, I.; Jovin, E. Antimicrobial and antioxidant properties of rosemary and sage (Rosmarinus officinalis L. and Salvia officinalis L., Lamiaceae) essential oils. J. Agric. Food Chem. 2007, 55, 7879-7885. [CrossRef] [PubMed]

93. Weerakkody, N.S.; Caffin, N.; Turner, M.S.; Dykes, G.A. In vitro antimicrobial activity of less-utilized spice and herb extracts against selected food-borne bacteria. Food Control 2010, 21, 1408-1414. [CrossRef] 
94. Krajcova, E.; Greifova, M.; Schmidt, S. Study of antimicrobial activity of selected plant extracts against bacterial food contaminants. J. Food Nutr. Res. 2008, 47, 125-130.

95. Zhang, H.Y.; Kong, B.H.; Xiong, Y.; Sun, X. Antimicrobial activities of spice extracts against pathogenic and spoilage bacteria in modified atmosphere packaged fresh pork and vacuum packaged ham slices stored at $4{ }^{\circ}$ C. Meat Sci. 2009, 81, 686-692. [CrossRef] [PubMed]

96. Kozlowska, M.; Laudy, A.E.; Przybyl, J.; Ziarno, M.; Majewska, E. Chemical composition and antibacterial activity of some medicinal plants from Lamiaceae family. ACTA Pol. Pharm. 2015, 72, 757-767. [PubMed]

97. Weerakkody, N.S.; Caffin, N.; Dykes, G.A.; Turner, M.S. Effect of antimicrobial spice and herb extract combinations on Listeria monocytogenes, Staphylococcus aureus, and Spoilage Microflora growth on cooked ready-to-eat vacuum-packaged shrimp. J. Food Prot. 2011, 74, 1119-1125. [CrossRef] [PubMed]

98. Nejad, A.; Shabani, S.; Bayat, M.; Hosseini, S.E. Antibacterial effect of garlic aqueous extract on Staphylococcus aureus in hamburger. Jundishapur J. Microbiol. 2014, 7, e13134.

99. Rahman, M.S.; Al-Sheibani, H.I.; Al-Riziqi, M.H.; Mothershaw, A.; Guizani, N.; Bengtsson, G. Assessment of the anti-microbial activity of dried garlic powders produced by different methods of drying. Int. J. Food Prop. 2006, 9, 503-513. [CrossRef]

100. Sallam, K.I.; Ishloroshi, M.; Samejima, K. Antioxidant and antimicrobial effects of garlic in chicken sausage. LWT-Food Sci. Technol. 2004, 37, 849-855. [CrossRef] [PubMed]

101. Aydin, A.; Bostan, K.; Erkan, M.E.; Bingol, B. The antimicrobial effects of chopped garlic in ground beef and raw meatball (Çið Köfte). J. Med. Food 2007, 10, 203-207. [CrossRef] [PubMed]

102. Li, W.; Shi, Q.; Dai, H.; Liang, Q.; Xie, X.; Huang, X.; Zhao, G.; Zhang, L. Antifungal activity, kinetics and molecular mechanism of action of garlic oil against Candida albicans. Sci. Rep. UK 2016, 6, 22805. [CrossRef] [PubMed]

103. Indu, M.N.; Hatha, A.; Abirosh, C.; Harsha, U.; Vivekanandan, G. Antimicrobial activity of some of the south-Indian spices against serotypes of Escherichia coli, Salmonella, Listeria monocytogenes and Aeromonas hydrophila. Braz. J. Microbiol. 2006, 37, 153-158. [CrossRef]

104. Joe, M.M.; Jayachitra, J.; Vijayapriya, M. Antimicrobial activity of some common spices against certain human pathogens. J. Med. Plants Res. 2009, 3, 1134-1136.

105. Geremew, T.; Kebede, A.; Andualem, B. The role of spices and lactic acid bacteria as antimicrobial agent to extend the shelf life of metata ayib (traditional Ethiopian spiced fermented cottage cheese). J. Food Sci. Technol. Mysore 2015, 52, 5661-5670. [CrossRef] [PubMed]

106. Touba, E.P.; Zakaria, M.; Tahereh, E. Anti-fungal activity of cold and hot water extracts of spices against fungal pathogens of roselle (Hibiscus sabdariffa) in vitro. Microb. Pathog. 2012, 52, 125-129. [CrossRef] [PubMed]

107. Park, M.; Bae, J.; Lee, D.S. Antibacterial activity of [10]-gingerol and [12]-gingerol isolated from ginger rhizome against periodontal bacteria. Phytother. Res. 2008, 22, 1446-1449. [CrossRef] [PubMed]

108. Sa-Nguanpuag, K.; Kanlayanarat, S.; Srilaong, V.; Tanprasert, K.; Techavuthiporn, C. Ginger (Zingiber officinale) oil as an antimicrobial agent for minimally processed produce: A case study in shredded green papaya. Int. J. Agric. Biol. 2011, 13, 895-901.

109. Singh, G.; Maurya, S.; Catalan, C.; de Lampasona, M.P. Studies on essential oils, Part 42: Chemical, antifungal, antioxidant and sprout suppressant studies on ginger essential oil and its oleoresin. Flavour Frag. J. 2005, 20, 1-6. [CrossRef]

110. Yoo, M.J.; Kim, Y.S.; Shin, D.H. Antibacterial effects of natural essential oils from ginger and mustard against Vibrio species inoculated on sliced raw flatfish. Food Sci. Biotechnol. 2006, 15, 462-465.

111. Thongson, C.; Davidson, P.M.; Mahakarnchanakul, W.; Vibulsresth, P. Antimicrobial effect of Thai spices against Listeria monocytogenes and Salmonella typhimurium DT104. J. Food Prot. 2005, 68, 2054-2058. [CrossRef] [PubMed]

112. Suppakul, P.; Miltz, J.; Sonneveld, K.; Bigger, S.W. Antimicrobial properties of basil and its possible application in food packaging. J. Agric. Food Chem. 2003, 51, 3197-3207. [CrossRef] [PubMed]

113. Hussain, A.I.; Anwar, F.; Sherazi, S.; Przybylski, R. Chemical composition, antioxidant and antimicrobial activities of basil (Ocimum basilicum) essential oils depends on seasonal variations. Food Chem. 2008, 108, 986-995. [CrossRef] [PubMed] 
114. Kaya, I.; Yigit, N.; Benli, M. Antimicrobial activity of various extracts of Ocimum basilicum L. and observation of the inhibition effect on bacterial cells by use of scanning electron microscopy. Afr. J. Tradit. Complement. Altern. Med. 2008, 5, 363-369. [CrossRef] [PubMed]

115. Kocic-Tanackov, S.; Dimic, G.; Levic, J.; Tanackov, I.; Tuco, D. Antifungal activities of basil (Ocimum basilicum L.) extract on Fusarium species. Afr. J. Biotechnol. 2011, 10, 10188-10195.

116. Beatovic, D.; Krstic-Milosevic, D.; Trifunovic, S.; Siljegovic, J.; Glamoclija, J.; Ristic, M.; Jelacic, S. Chemical composition, antioxidant and antimicrobial activities of the essential oils of twelve Ocimum basilicum $\mathrm{L}$. cultivars grown in Serbia. Rec. Nat. Prod. 2015, 9, 62-75.

117. El-Habib, R. Antifungal activity of some essential oils on Aspergillus flavus growth and aflatoxin production. J. Food Agric. Environ. 2012, 10, 274-279.

118. Singh, G.; Maurya, S.; de Lampasona, M.P.; Catalan, C. Chemical constituents, antifungal and antioxidative potential of Foeniculum vulgare volatile oil and its acetone extract. Food Control 2006, 17, 745-752. [CrossRef]

119. Diao, W.R.; Hu, Q.P.; Zhang, H.; Xu, J.G. Chemical composition, antibacterial activity and mechanism of action of essential oil from seeds of fennel (Foeniculum vulgare Mill.). Food Control 2014, 35, 109-116. [CrossRef]

120. Park, J.S.; Baek, H.H.; Bai, D.H.; Oh, T.K.; Lee, C.H. Antibacterial activity of fennel (Foeniculum vulgare Mill.) seed essential oil against the growth of Streptococcus mutans. Food Sci. Biotechnol. 2004, 13, 581-585.

121. Zellagui, A.; Gherraf, N.; Elkhateeb, A.; Hegazy, M.; Mohamed, T.A.; Touil, A.; Shahat, A.A.; Rhouati, S. Chemical constituents from Algerian Foeniculum Vulgare aerial parts and evaluation of antimicrobial activity. J. Chil. Chem. Soc. 2011, 56, 759-763. [CrossRef]

122. Bisht, D.S.; Menon, K.; Singhal, M.K. Comparative antimicrobial activity of essential oils of Cuminum cyminum L. and Foeniculum vulgare Mill seeds against Salmonella typhimurium and Escherichia coli. J. Essent. Oil Bear. Plants 2014, 17, 617-622. [CrossRef]

123. Nguyen, S.; Huang, H.; Foster, B.C.; Tam, T.W.; Xing, T.; Smith, M.L.; Arnason, J.T.; Akhtar, H. Antimicrobial and P450 inhibitory properties of common functional foods. J. Pharm. Pharm. Sci. 2014, 17, 254-265. [CrossRef]

124. Duarte, A.; Luis, A.; Oleastro, M.; Domingues, F.C. Antioxidant properties of coriander essential oil and linalool and their potential to control Campylobacter spp. Food Control 2016, 61, 115-122. [CrossRef]

125. Duarte, A.F.; Ferreira, S.; Oliveira, R.; Domingues, F.C. Effect of coriander oil (Coriandrum sativum) on planktonic and biofilm cells of Acinetobacter baumannii. Nat. Prod. Commun. 2013, 8, 673-678.

126. Duarte, A.; Ferreira, S.; Silva, F.; Domingues, F.C. Synergistic activity of coriander oil and conventional antibiotics against Acinetobacter baumannii. Phytomedicine 2012, 19, 236-238. [CrossRef] [PubMed]

127. Freires, I.D.; Murata, R.M.; Furletti, V.F.; Sartoratto, A.; de Alencar, S.M.; Figueira, G.M.; Rodrigues, J.; Duarte, M.; Rosalen, P.L. Coriandrum sativum L. (coriander) essential oil: Antifungal activity and mode of action on Candida spp., and molecular targets affected in human whole-genome expression. PLoS ONE 2014, 9, e99086.

128. Silva, F.; Ferreira, S.; Queiroz, J.A.; Domingues, F.C. Coriander (Coriandrum sativum L.) essential oil: Its antibacterial activity and mode of action evaluated by flow cytometry. J. Med. Microbiol. 2011, 60, 1479-1486. [CrossRef] [PubMed]

129. Acimovic, M.G.; Grahovac, M.S.; Stankovic, J.M.; Cvetkovic, M.T.; Masirevic, S.N. Essential oil composition of different coriander (Coriandrum sativum L.) accessions and their influence on mycelial growth of Colletotrichum spp. Acta Sci. Pol. Hortorum Cultus 2016, 15, 35-44.

130. Singh, G.; Maurya, S.; de Lampasona, M.P.; Catalan, C. Studies on essential oils, Part 41. Chemical composition, antifungal, antioxidant and sprout suppressant activities of coriander (Coriandrum sativum) essential oil and its oleoresin. Flavour Frag. J. 2006, 21, 472-479. [CrossRef]

131. Yakout, S.M.; Abd-Alrahman, S.H.; Mostafa, A.; Salem-Bekhit, M.M. Antimicrobial effect of seed ethanolic extract of coriander. J. Pure Appl. Microbiol. 2013, 7, 459-463.

132. Dimic, G.; Kocic-Tanackov, S.; Mojovic, L.; Pejin, J. Antifungal activity of lemon essential oil, coriander and cinnamon extracts on foodborne molds in direct contact and the vapor phase. J. Food Process. Pres. 2015, 39, 1778-1787. [CrossRef]

133. Rao, K.; Ch, B.; Narasu, L.M.; Giri, A. Antibacterial activity of Alpinia galanga (L.) willd crude extracts. Appl. Biochem. Biotechnol. 2010, 162, 871-884. [CrossRef] [PubMed] 
134. Weerakkody, N.S.; Caffin, N.; Lambert, L.K.; Turner, M.S.; Dykes, G.A. Synergistic antimicrobial activity of galangal (Alpinia galanga), rosemary (Rosmarinus officinalis) and lemon iron bark (Eucalyptus staigerana) extracts. J. Sci. Food Agric. 2011, 91, 461-468. [CrossRef] [PubMed]

135. Wong, L.F.; Lim, Y.Y.; Omar, M. Antioxidant and antimicrobial activities of some Alpina species. J. Food Biochem. 2009, 33, 835-851. [CrossRef]

136. Singh, G.; Marimuthu, P.; Catalan, C.; DeLampasona, M.P. Chemical, antioxidant and antifungal activities of volatile oil of black pepper and its acetone extract. J. Sci. Food Agric. 2004, 84, 1878-1884. [CrossRef]

137. Singh, G.; Marimuthu, P.; Murali, H.S.; Bawa, A.S. Antioxidative and antibacterial potentials of essential oils and extracts isolated from various spice materials-Part 48. J. Food Saf. 2005, 25, 130-145. [CrossRef]

138. Zarai, Z.; Boujelbene, E.; Ben Salem, N.; Gargouri, Y.; Sayari, A. Antioxidant and antimicrobial activities of various solvent extracts, piperine and piperic acid from Piper nigrum. LWT-Food Sci. Technol. 2013, 50, 634-641. [CrossRef]

139. Zhang, J.; Ye, K.; Zhang, X.; Pan, D.; Sun, Y.; Cao, J. Antibacterial activity and mechanism of action of black pepper essential oil on meat-borne Escherichia coli. Front. Microbiol. 2017, 7. [CrossRef] [PubMed]

140. Baris, D.; Kizil, M.; Aytekin, C.; Kizil, G.; Yavuz, M.; Ceken, B.; Ertekin, A.S. In vitro antimicrobial and antioxidant activity of ethanol extract of three Hypericum and three Achillea species from Turkey. Int. J. Food Prop. 2011, 14, 339-355. [CrossRef]

141. Tajik, H.; Jalali, F.; Sobhani, A.; Shahbazi, Y.; Zadeh, M.S. In vitro assessment of antimicrobial efficacy of alcoholic extract of Achillea millefolium in comparison with penicillin derivatives. J. Anim. Vet. Adv. 2008, 7, 508-511.

142. Eyob, S.; Martinsen, B.K.; Tsegaye, A.; Appelgren, M.; Skrede, G. Antioxidant and antimicrobial activities of extract and essential oil of korarima (Aframomum corrorima (Braun) P.C.M. Jansen). Afr. J. Biotechnol. 2008, 7, $2585-2592$.

143. Ismail, S.; Jalilian, F.A.; Talebpour, A.H.; Zargar, M.; Shameli, K.; Sekawi, Z.; Jahanshiri, F. Chemical composition and antibacterial and cytotoxic activities of Allium hirtifolium Boiss. BioMed Res. Int. 2013, 2013. [CrossRef] [PubMed]

144. Najjaa, H.; Ammar, E.; Neffati, M. Antimicrobial activities of protenic extracts of Allium roseum L., a wild edible species in North Africa. J. Food Agric. Environ. 2009, 7, 150-154.

145. Mihaylova, D.S.; Lante, A.; Tinello, F.; Krastanov, A.I. Study on the antioxidant and antimicrobial activities of Allium ursinum L. pressurised-liquid extract. Nat. Prod. Res. 2014, 28, 2000-2005. [CrossRef] [PubMed]

146. Diao, W.R.; Zhang, L.L.; Feng, S.S.; Xu, J.G. Chemical composition, antibacterial activity, and mechanism of action of the essential oil from Amomum kravanh. J. Food Prot. 2014, 77, 1740-1746. [CrossRef]

147. Singh, G.; Maurya, S.; de Lampasona, M.P.; Catalan, C. Chemical constituents, antimicrobial investigations, and antioxidative potentials of Anethum graveolens L. essential oil and acetone extract: Part 52. J. Food Sci. 2005, 70, M208-M215. [CrossRef]

148. Akkoyun, H.T.; Dostbil, N. Antibacterial activity of some species of Umbelliferae. Asian J. Chem. 2007, 19, 4862-4866.

149. Sofia, P.K.; Prasad, R.; Vijay, V.K.; Srivastava, A.K. Evaluation of antibacterial activity of Indian spices against common foodborne pathogens. Int. J. Food Sci. Technol. 2007, 42, 910-915. [CrossRef]

150. Sekine, T.; Sugano, M.; Majid, A.; Fujii, Y. Antifungal effects of volatile compounds from black zira (Bunium persicum) and other spices and herbs. J. Chem. Ecol. 2007, 33, 2123-2132. [CrossRef] [PubMed]

151. Mishra, P.K.; Shukla, R.; Singh, P.; Prakash, B.; Dubey, N.K. Antifungal and antiaflatoxigenic efficacy of Caesulia axillaris Roxb essential oil against fungi deteriorating some herbal raw materials, and its antioxidant activity. Ind. Crop. Prod. 2012, 36, 74-80. [CrossRef]

152. Wahba, N.M.; Ahmed, A.S.; Ebraheim, Z.Z. Antimicrobial effects of pepper, parsley, and dill and their roles in the microbiological quality enhancement of traditional Egyptian kareish cheese. Foodborne Pathog. Dis. 2010, 7, 411-418. [CrossRef] [PubMed]

153. Gurnani, N.; Gupta, M.; Shrivastava, R.; Mehta, D.; Mehta, B.K. Effect of extraction methods on yield, phytochemical constituents, antibacterial and antifungal activity of Capsicum frutescens L. Indian J. Nat. Prod. Resour. 2016, 7, 32-39.

154. Singh, G.; Kapoor, I.; Pandey, S.K.; Singh, U.K.; Singh, R.K. Studies on essential oils: Part 10; Antibacterial activity of volatile oils of some spices. Phytother. Res. 2002, 16, 680-682. [CrossRef] [PubMed] 
155. Oroojalian, F.; Kasra-Kermanshahi, R.; Azizi, M.; Bassami, M.R. Phytochemical composition of the essential oils from three Apiaceae species and their antibacterial effects on food-borne pathogens. Food Chem. 2010, 120, 765-770. [CrossRef]

156. Shan, B.; Cai, Y.Z.; Brooks, J.D.; Corke, H. Antibacterial properties and major bioactive components of cinnamon stick (Cinnamomum burmannii): Activity against foodborne pathogenic bacteria. J. Agric. Food Chem. 2007, 55, 5484-5490. [CrossRef] [PubMed]

157. Pandey, A.K.; Mishra, A.K.; Mishra, A. Antifungal and antioxidative potential of oil and extracts derived from leaves of Indian spice plant Cinnamomum tamala. Cell. Mol. Biol. 2012, 58, 142-147. [PubMed]

158. Shreya, A.; Manisha, D.; Sonali, J. Phytochemical screening and anti-microbial activity of cinnamon spice against urinary tract infection and fungal pathogens. Int. J. Life Sci. Pharma Res. 2015, 5, P30-P38.

159. Naveed, R.; Hussain, I.; Mahmood, M.S.; Akhtar, M. In vitro and in vivo evaluation of antimicrobial activities of essential oils extracted from some indigenous spices. Pak. Vet. J. 2013, 33, 413-417.

160. Naveed, R.; Hussain, I.; Tawab, A.; Tariq, M.; Rahman, M.; Hameed, S.; Mahmood, M.S.; Siddique, A.; Iqbal, M. Antimicrobial activity of the bioactive components of essential oils from Pakistani spices against Salmonella and other multi-drug resistant bacteria. BMC Complement. Altern. Med. 2013, 13, 265. [CrossRef] [PubMed]

161. Hashemi, S.; Amininezhad, R.; Shirzadinezhad, E.; Farahani, M.; Yousefabad, S. The antimicrobial and antioxidant effects of Citrus aurantium L. flowers (Bahar narang) extract in traditional yoghurt stew during refrigerated storage. J. Food Saf. 2016, 36, 153-161. [CrossRef]

162. Castilho, P.; Liu, K.; Rodrigues, A.I.; Feio, S.; Tomi, F.; Casanova, J. Composition and antimicrobial activity of the essential oil of Clinopodium ascendens (Jordan) Sampaio from Madeira. Flavour Frag. J. 2007, 22, 139-144. [CrossRef]

163. Oussalah, M.; Caillet, S.; Saucier, L.; Lacroix, M. Antimicrobial effects of selected plant essential oils on the growth of a Pseudomonas putida strain isolated from meat. Meat Sci. 2005, 73, 236-244. [CrossRef] [PubMed]

164. Sani, A.M.; Yaghooti, F. Antibacterial effects and chemical composition of essential oil from Cotoneaster nummularioides leaves extract on typical food-borne pathogens. J. Essent. Oil Bear. Plants 2016, 19, 290-296. [CrossRef]

165. Daouda, T.; Prevost, K.; Gustave, B.; Joseph, D.A.; Nathalie, G.; Raphael, O.; Rubens, D.; Claude, C.J.; Mireille, D.; Felix, T. Terpenes, antibacterial and modulatory antibiotic activity of essential oils from Croton hirtus L' Hér. (Euphorbiaceae) from Ivory Coast. J. Essent. Oil Bear. Plants 2014, 17, 607-616. [CrossRef]

166. Ani, V.; Varadaraj, M.C.; Naidu, K.A. Antioxidant and antibacterial activities of polyphenolic compounds from bitter cumin (Cuminum nigrum L.). Eur. Food Res. Technol. 2006, 224, 109-115. [CrossRef]

167. Li, X.F.; Jin, C.; He, J.; Zhou, J.; Wang, H.T.; Dai, B.; Yan, D.; Wang, J.B.; Zhao, Y.L.; Xiao, X.H. Microcalorimetric investigation of the antibacterial activity of curcumin on Staphylococcus aureus coupled with multivariate analysis. J. Therm. Anal. Calorim. 2012, 109, 395-402. [CrossRef]

168. Sandri, I.G.; Zacaria, J.; Fracaro, F.; Delamare, A.; Echeverrigaray, S. Antimicrobial activity of the essential oils of Brazilian species of the genus Cunila against foodborne pathogens and spoiling bacteria. Food Chem. 2007, 103, 823-828. [CrossRef]

169. Fankam, A.G.; Kuete, V.; Voukeng, I.K.; Kuiate, J.R.; Pages, J.M. Antibacterial activities of selected Cameroonian spices and their synergistic effects with antibiotics against multidrug-resistant phenotypes. BMC Complement. Altern. Med. 2011, 11, 104. [CrossRef] [PubMed]

170. Tekwu, E.M.; Askun, T.; Kuete, V.; Nkengfack, A.E.; Nyasse, B.; Etoa, F.X.; Beng, V.P. Antibacterial activity of selected Cameroonian dietary spices ethno-medically used against strains of Mycobacterium tuberculosis. J. Ethnopharmacol. 2012, 142, 374-382. [CrossRef] [PubMed]

171. El Malti, J.; Mountassif, D.; Amarouch, H. Antimicrobial activity of Elettaria cardamomum: Toxicity, biochemical and histological studies. Food Chem. 2007, 104, 1560-1568. [CrossRef]

172. Singh, G.; Kim, S.; Marimuthu, P.; Isidorov, V.; Vinogorova, V. Antioxidant and antimicrobial activities of essential oil and various oleoresins of Elettaria cardamomum (seeds and pods). J. Sci. Food Agric. 2008, 88, 280-289. [CrossRef]

173. Bey-Ould Si Said, Z.; Haddadi-Guemghar, H.; Boulekbache-Makhlouf, L.; Rigou, P.; Remini, H.; Adjaoud, A.; Khoudja, N.K.; Madani, K. Essential oils composition, antibacterial and antioxidant activities of hydrodistillated extract of Eucalyptus globulus fruits. Ind. Crop. Prod. 2016, 89, 167-175. [CrossRef] 
174. Nikbakht, M.R.; Rahimi-Nasrabadi, M.; Ahmadi, F.; Gandomi, H.; Abbaszadeh, S.; Batooli, H. The chemical composition and in vitro antifungal activities of essential oils of five Eucalyptus species. J. Essent. Oil Bear. Plants 2015, 18, 666-677. [CrossRef]

175. Luís, Â.; Duarte, A.; Gominho, J.; Domingues, F.; Duarte, A.P. Chemical composition, antioxidant, antibacterial and anti-quorum sensing activities of Eucalyptus globulus and Eucalyptus radiata essential oils. Ind. Crop. Prod. 2016, 79, 274-282. [CrossRef]

176. Puangpronpitag, D.; Niamsa, N.; Sittiwet, C. Anti-microbial properties of clove (Eugenia caryophyllum Bullock and Harrison) aqueous extract against food-borne pathogen bacteria. Int. J. Pharmacol. 2009, 5, 281-284.

177. Ozcan, M.M.; Chalchat, J.C.; Arslan, D.; Ates, A.; Unver, A. Comparative essential oil composition and antifungal effect of bitter fennel (Foeniculum vulgare ssp. piperitum) fruit oils obtained during different vegetation. J. Med. Food 2006, 9, 552-561. [PubMed]

178. Soureshjan, E.H.; Heidari, M. In vitro variation in antibacterial activity plant extracts on Glaucium elegans and saffron (Crocus sativus). Bangladesh J. Pharmacol. 2014, 9, 275-278.

179. Khan, H.; Khan, M.A.; Mahmood, T.; Choudhary, M.I. Antimicrobial activities of Gloriosa superba Linn (Colchicaceae) extracts. J. Enzym. Inhib. Med. Chem. 2008, 23, 855-859. [CrossRef] [PubMed]

180. Albayrak, S.; Aksoy, A.; Sagdic, O.; Hamzaoglu, E. Compositions, antioxidant and antimicrobial activities of Helichrysum (Asteraceae) species collected from Turkey. Food Chem. 2010, 119, 114-122. [CrossRef]

181. Albayrak, S.; Aksoy, A.; Sagdic, O.; Budak, U. Phenolic compounds and antioxidant and antimicrobial properties of Helichrysum species collected from eastern Anatolia, Turkey. Turk. J. Biol. 2010, 34, 463-473.

182. Czapska, A.; Balasinska, B.; Szczawinski, J. Antimicrobial and antioxidant properties of aqueous extracts from selected spice plants. Med. Weter. 2006, 62, 302-305.

183. Džamiæ, A.M.; Sokoviæ, M.D.; Novakoviæ, M.; Jadranin, M.; Ristiæ, M.S.; Teševiæ, V.; Marin, P.D. Composition, antifungal and antioxidant properties of Hyssopus officinalis L. subsp pilifer (Pant.) Murb essential oil and deodorized extracts. Ind. Crop. Prod. 2013, 51, 401-407. [CrossRef]

184. Parlatan, A.; Saricoban, C.; Ozcan, M.M. Chemical composition and antimicrobial activity of the extracts of Kefe cumin (Laser trilobum L.) fruits from different regions. Int. J. Food Sci. Nutr. 2009, 60, 606-617. [CrossRef] [PubMed]

185. El Malti, J.; Amarouch, H. Antibacterial effect, histological impact and oxidative stress studies Fromlaurus nobilis extract. J. Food Qual. 2009, 32, 190-208. [CrossRef]

186. Ramos, C.; Teixeira, B.; Batista, I.; Matos, O.; Serrano, C.; Neng, N.R.; Nogueira, J.; Nunes, M.L.; Marques, A. Antioxidant and antibacterial activity of essential oil and extracts of bay laurel Laurus nobilis Linnaeus (Lauraceae) from Portugal. Nat. Prod. Res. 2012, 26, 518-529. [CrossRef] [PubMed]

187. Ceyhan, N.; Keskin, D.; Ugur, A. Antimicrobial activities of different extracts of eight plant species from four different family against some pathogenic microoorganisms. J. Food Agric. Environ. 2012, 10, 193-197.

188. Marín, I.; Sayas-Barberá, E.; Viuda-Martos, M.; Navarro, C.; Sendra, E. Chemical composition, antioxidant and antimicrobial activity of essential oils from organic fennel, parsley, and lavender from Spain. Foods 2016, 5, 18. [CrossRef]

189. Basile, A.; Rigano, D.; Loppi, S.; Di Santi, A.; Nebbioso, A.; Sorbo, S.; Conte, B.; Paoli, L.; de Ruberto, F.; Molinari, A.M. Antiproliferative, antibacterial and antifungal activity of the lichen Xanthoria parietina and its secondary metabolite parietin. Int. J. Mol. Sci. 2015, 16, 7861-7875. [CrossRef] [PubMed]

190. Sarrazin, S.; Oliveira, R.B.; Barata, L.; Mourao, R. Chemical composition and antimicrobial activity of the essential oil of Lippia grandis Schauer (Verbenaceae) from the western Amazon. Food Chem. 2012, 134, 1474-1478. [CrossRef] [PubMed]

191. Asowata-Ayodele, A.M.; Otunola, G.A.; Afolayan, A.J. Assessment of the polyphenolic content, free radical scavenging, anti-inflammatory, and antimicrobial activities of acetone and aqueous extracts of Lippia javanica (Burm.F.) Spreng. Pharmacogn. Mag. 2016, 12, S353-S362. [PubMed]

192. Oliveira, D.R.; Leitao, G.G.; Bizzo, H.R.; Lopes, D.; Alviano, D.S.; Alviano, C.S.; Leitao, S.G. Chemical and antimicrobial analyses of essential oil of Lippia origanoides HBK. Food Chem. 2007, 101, 236-240. [CrossRef]

193. Li, W.R.; Shi, Q.S.; Liang, Q.; Xie, X.B.; Huang, X.M.; Chen, Y.B. Antibacterial activity and kinetics of Litsea cubeba oil on Escherichia coli. PLoS ONE 2014, 9, e110983. [CrossRef] [PubMed]

194. Stanojevic, D.; Comic, L.; Stefanovic, O.; Sukdolak, S.S. In vitro synergistic antibacterial activity of Melissa officinalis L. and some preservatives. Span. J. Agric. Res. 2010, 8, 109-115. [CrossRef] 
195. Sharma, M.; Sharma, M. Antimicrobial potential of essential oil from Mentha piperita L. against anthropophilic dermatophytes. J. Essent. Oil Bear. Plants 2012, 15, 263-269. [CrossRef]

196. Arumugam, P.; Murugan, R.; Subathra, M.; Ramesh, A. Superoxide radical scavenging and antibacterial activities of different fractions of ethanol extract of Mentha spicata (L.). Med. Chem. Res. 2010, 19, 664-673. [CrossRef]

197. Esekhiagbe, M.; Agatemor, M.; Agatemor, C. Phenolic content and antimicrobial potentials of Xylopia aethiopica and Myristica argentea. Maced. J. Chem. Chem. Eng. 2009, 28, 159-162.

198. Shafiei, Z.; Shuhairi, N.N.; Yap, N.; Sibungkil, C.; Latip, J. Antibacterial activity of Myristica fragrans against oral pathogens. Evid. Based Complement. Altern. 2012, 2012. [CrossRef]

199. Mhamdi, B.; Abbassi, F.; Marzouki, L. Antimicrobial Activities effects of the essential oil of spice food Myrtus communis leaves vr. Italica. J. Essent. Oil Bear. Plants 2014, 17, 1361-1366. [CrossRef]

200. Ozcan, M.M.; Uyar, B.; Unver, A. Antibacterial effect of myrtle (Myrtus communis L.) leaves extract on microorganisms. J. Food Saf. Food Qual. 2015, 66, 18-21.

201. Popovici, J.; Bertrand, C.; Bagnarol, E.; Fernandez, M.P.; Comte, G. Chemical composition of essential oil and headspace-solid microextracts from fruits of Myrica gale L. and antifungal activity. Nat. Prod. Res. 2008, 22, 1024-1032. [CrossRef] [PubMed]

202. Aboee-Mehrizi, F.; Rustaiyan, A.; Zare, M. Chemical composition and antimicrobial activity of the essential oils of Nepeta alpina growing wild in Iran. J. Essent. Oil Bear. Plants 2016, 19, 236-240. [CrossRef]

203. Arslan, U.; Ilhan, K.; Karabulut, O.A. Antifungal activity of aqueous extracts of spices against bean rust (Uromyces appendiculatus). Allelopath. J. 2009, 24, 207-213.

204. Arici, M.; Sagdic, O.; Gecgel, U. Antibacterial effect of Turkish black cumin (Nigella sativa L.) oils. Grasas Aceites 2005, 56, 259-262. [CrossRef]

205. Wouatsa, N.; Misra, L.; Kumar, R.V. Antibacterial activity of essential oils of edible spices, Ocimum canum and Xylopia aethiopica. J. Food Sci. 2014, 79, M972-M977. [CrossRef] [PubMed]

206. Prakash, B.; Shukla, R.; Singh, P.; Mishra, P.K.; Dubey, N.K.; Kharwar, R.N. Efficacy of chemically characterized Ocimum gratissimum L. essential oil as an antioxidant and a safe plant based antimicrobial against fungal and aflatoxin $\mathrm{B}_{1}$ contamination of spices. Food Res. Int. 2011, 44, 385-390. [CrossRef]

207. Kumar, A.; Dubey, N.K.; Srivastaya, S. Antifungal evaluation of Ocimum sanctum essential oil against fungal deterioration of raw materials of Rauvolfia serpentina during storage. Ind. Crop. Prod. 2013, 45, 30-35. [CrossRef]

208. Saharkhiz, M.J.; Kamyab, A.A.; Kazerani, N.K.; Zomorodian, K.; Pakshir, K.; Rahimi, M.J. Chemical compositions and antimicrobial activities of Ocimum sanctum L. essential oils at different harvest stages. Jundishapur J. Microbiol. 2015, 8, e13720. [CrossRef] [PubMed]

209. Runyoro, D.; Ngassapa, O.; Vagionas, K.; Aligiannis, N.; Graikou, K.; Chinou, I. Chemical composition and antimicrobial activity of the essential oils of four Ocimum species growing in Tanzania. Food Chem. 2010, 119, 311-316. [CrossRef]

210. Ali, N.H.; Faizi, S.; Kazmi, S.U. Antibacterial activity in spices and local medicinal plants against clinical isolates of Karachi, Pakistan. Pharm. Biol. 2011, 49, 833-839. [CrossRef] [PubMed]

211. Yano, Y.; Satomi, M.; Oikawa, H. Antimicrobial effect of spices and herbs on Vibrio parahaemolyticus. Int. J. Food Microbiol. 2006, 111, 6-11. [CrossRef] [PubMed]

212. Seydim, A.C.; Sarikus, G. Antimicrobial activity of whey protein based edible films incorporated with oregano, rosemary and garlic essential oils. Food Res. Int. 2006, 39, 639-644. [CrossRef]

213. Ho, C.H.; Noryati, I.; Sulaiman, S.F.; Rosma, A. In vitro antibacterial and antioxidant activities of Orthosiphon stamineus Benth extracts against food-borne bacteria. Food Chem. 2010, 122, 1168-1172. [CrossRef]

214. Boyd, F.; Benkeblia, N. In vitro evaluation of antimicrobial activity of crude extracts of Pimenta dioica L. (Merr.). In Proceedings of the 3rd International Conference on Postharvest and Quality Management of Horticultural Products of Interest for Tropical Regions, Port of Spain, Trinid \& Tobago, 1-5 July 2013; Mohammed, M., Francis, J.A., Eds.; International Society for Horticultural Science: Leuven, Belgium, 2014; pp. 199-205.

215. Ozcan, M.M.; Chalchat, J.C. Chemical composition and antifungal effect of anise (Pimpinella anisum L.) fruit oil at ripening stage. Ann. Microbiol. 2006, 56, 353-358. [CrossRef] 
216. Woguem, V.; Maggi, F.; Fogang, H.; Tapondjou, L.A.; Womeni, H.M.; Quassinti, L.; Bramucci, M.; Vitali, L.A.; Petrelli, D.; Lupidi, G.; et al. Antioxidant, antiproliferative and antimicrobial activities of the volatile oil from the wild pepper piper capense used in Cameroon as a culinary spice. Nat. Prod. Commun. 2013, 8, 1791-1796. [PubMed]

217. Eruteya, O.C.; Odunfa, S.A. Antimicrobial properties of three spices used in the preparation of suya condiment against organisms isolated from formulated samples and individual ingredients. Afr. J. Biotechnol. 2009, 8, 2316-2320.

218. Toroglu, S.; Cenet, M. Comparison of antimicrobial activities of essential oil and solvent extracts of endemic Phlomis oppositiflora Boiss. \& Hausskn. from Turkey. Pak. J. Zool. 2013, 45, 475-482.

219. Sahin, S.; Oran, S.; Sahinturk, P.; Demir, C.; Ozturk, S. Ramalina lichens and their major metabolites as possible natural antioxidant and antimicrobial agents. J. Food Biochem. 2015, 39, 471-477. [CrossRef]

220. Fazeli, M.R.; Amin, G.; Attari, M.; Ashtiani, H.; Jamalifar, H.; Samadi, N. Antimicrobial activities of Iranian sumac and avishan-e shirazi. (Zataria multiflora) against some food-borne bacteria. Food Control 2007, 18, 646-649. [CrossRef]

221. Aliakbarlu, J.; Mohammadi, S.; Khalili, S. A study on antioxidant potency and antibacterial activity of water extracts of some spices widely consumed in Iranian diet. J. Food Biochem. 2014, 38, 159-166. [CrossRef]

222. Mekinic, I.G.; Skroza, D.; Ljubenkov, I.; Simat, V.; Mozina, S.S.; Katalinic, V. In vitro antioxidant and antibacterial activity of Lamiaceae phenolic extracts: A correlation study. Food Technol. Biotechnol. 2014, 52, 119-127.

223. Bouajaj, S.; Benyamna, A.; Bouamama, H.; Romane, A.; Falconieri, D.; Piras, A.; Marongiu, B. Antibacterial, allelopathic and antioxidant activities of essential oil of Salvia officinalis L. growing wild in the Atlas Mountains of Morocco. Nat. Prod. Res. 2013, 27, 1673-1676. [CrossRef] [PubMed]

224. Mehr, H.M.; Hosseini, Z.; Khodaparast, M.; Edalatian, M.R. Study on the antimicrobial effect of Salvia leriifolia (nowroozak) leaf extract powder on the growth of Staphylococcus aureus in hamburger. J. Food Saf. 2010, 30, 941-953. [CrossRef]

225. Djeddi, S.; Djebile, K.; Hadjbourega, G.; Achour, Z.; Argyropoulou, C.; Skaltsa, H. In vitro Antimicrobial properties and chemical composition of Santolina chamaecyparissus essential oil from Algeria. Nat. Prod. Commun. 2012, 7, 937-940. [PubMed]

226. Oke, F.; Aslim, B.; Ozturk, S.; Altundag, S. Essential oil composition, antimicrobial and antioxidant activities of Satureja cuneifolia Ten. Food Chem. 2009, 112, 874-879. [CrossRef]

227. Mihajilov-Krstev, T.; Kitic, D.; Radnovic, D.; Ristic, M.; Mihajlovic-Ukropina, M.; Zlatkovic, B. Chemical composition and antimicrobial activity of Satureja kitaibelii essential oil against pathogenic microbial strains. Nat. Prod. Commun. 2011, 6, 1167-1172. [PubMed]

228. Yucel, N.; Aslim, B. Antibacterial activity of the essential oil of Satureja wiedemanniana against Bacillus species isolated from chicken meat. Foodborne Pathog. Dis. 2011, 8, 71-76. [CrossRef] [PubMed]

229. Farzaneh, M.; Kiani, H.; Sharifi, R.; Reisi, M.; Hadian, J. Chemical composition and antifungal effects of three species of Satureja (S. hortensis, S. spicigera and S. khuzistanica) essential oils on the main pathogens of strawberry fruit. Postharvest Biol. Technol. 2015, 109, 145-151.

230. Toroglu, S.; Keskin, D.; Dadandi, M.Y.; Yildiz, K. Comparision of antimicrobial activity of Silene laxa Boiss. \& Kotschy and Silene caramanica Boiss. \& Heldr different extracts from Turkey. J. Pure Appl. Microbiol. 2013, 7, 1763-1768.

231. Ozcan, M.M.; Al Juhaimi, F.Y. Antioxidant and antifungal activity of some aromatic plant extracts. J. Med. Plants Res. 2011, 5, 1361-1366.

232. El Abed, N.; Kaabi, B.; Smaali, M.I.; Chabbouh, M.; Habibi, K.; Mejri, M.; Marzouki, M.N.; Ahmed, S.B. Chemical composition, antioxidant and antimicrobial activities of Thymus capitata essential oil with its preservative effect against Listeria monocytogenes inoculated in minced beef meat. Evid. Based Complement. Altern. 2014, 2014. [CrossRef]

233. Ballester-Costa, C.; Sendra, E.; Fernandez-Lopez, J.; Perez-Alvarez, J.A.; Viuda-Martos, M. Chemical composition and in vitro antibacterial properties of essential oils of four Thymus species from organic growth. Ind. Crop. Prod. 2013, 50, 304-311. [CrossRef]

234. Albayrak, S.; Aksoy, A. Essential oil composition and in vitro antioxidant and antimicrobial activities of Thymus cappadocicus Boiss. J. Food Process Preserv. 2013, 37, 605-614. [CrossRef] 
235. Toroglu, S. In vitro antimicrobial activity and antagonistic effect of essential oils from plant species. J. Environ. Biol. 2007, 28, 551-559. [PubMed]

236. Ruiz-Navajas, Y.; Viuda-Martos, M.; Sendra, E.; Perez-Alvarez, J.A.; Fernández-López, J. Chemical characterization and antibacterial activity of Thymus moroderi and Thymus piperella essential oils, two Thymus endemic species from southeast of Spain. Food Control 2012, 27, 294-299. [CrossRef]

237. Georgescu, C.; Mironescu, M. Obtaining, characterisation and screening of the antifungal activity of the volatile oil extracted from Thymus serpyllum. J. Environ. Prot. Ecol. 2011, 12, 2294-2302.

238. Singh, G.; Maurya, S.; Catalan, C.; de Lampasona, M.P. Chemical constituents, antifungal and antioxidative effects of ajwain essential oil and its acetone extract. J. Agric. Food Chem. 2004, 52, 3292-3296. [CrossRef] [PubMed]

239. Adesegun, E.A.; Adebayo, O.S.; Akintokun, A.K. Antifungal activity of spices extracts against Sclerotium rolfsii. In Proceedings of the 28th International Horticultural Congress on Science and Horticulture for People (IHC)/International Symposium on Organic Horticulture-Productivity and Sustainability, Lisbon, Portugal, 22-27 August 2010; Mourao, I., Aksoy, U., Eds.; International Society for Horticultural Science: Leuven, Belgium, 2012; pp. 415-419.

240. Kusuda, M.; Inada, K.; Ogawa, T.O.; Yoshida, T.; Shiota, S.; Tsuchiya, T.; Hatano, T. Polyphenolic constituent structures of Zanthoxylum piperitum fruit and the antibacterial effects of its polymeric procyanidin on methicillin-resistant Staphylococcus aureus. Biosci. Biotechnol. Biochem. 2006, 70, 1423-1431. [CrossRef] [PubMed]

241. Diao, W.R.; Hu, Q.P.; Feng, S.S.; Li, W.Q.; Xu, J.G. Chemical composition and antibacterial activity of the essential oil from green huajiao (Zanthoxylum schinifolium) against selected foodborne pathogens. J. Agric. Food Chem. 2013, 61, 6044-6049. [CrossRef] [PubMed]

(C) 2017 by the authors. Licensee MDPI, Basel, Switzerland. This article is an open access article distributed under the terms and conditions of the Creative Commons Attribution (CC BY) license (http://creativecommons.org/licenses/by/4.0/). 